CRANE CREEK KNOWN GEOTHERMAL RESOURCE AREA:

AN ENVIRONMENTAL ANALYSIS

Susan G. Spencer

Brent F. Russell

Editors

\title{
MASTER
}

\section{U.S. Department of Energy}

Idaho Operations Office • Idaho National Engineering Laboratory

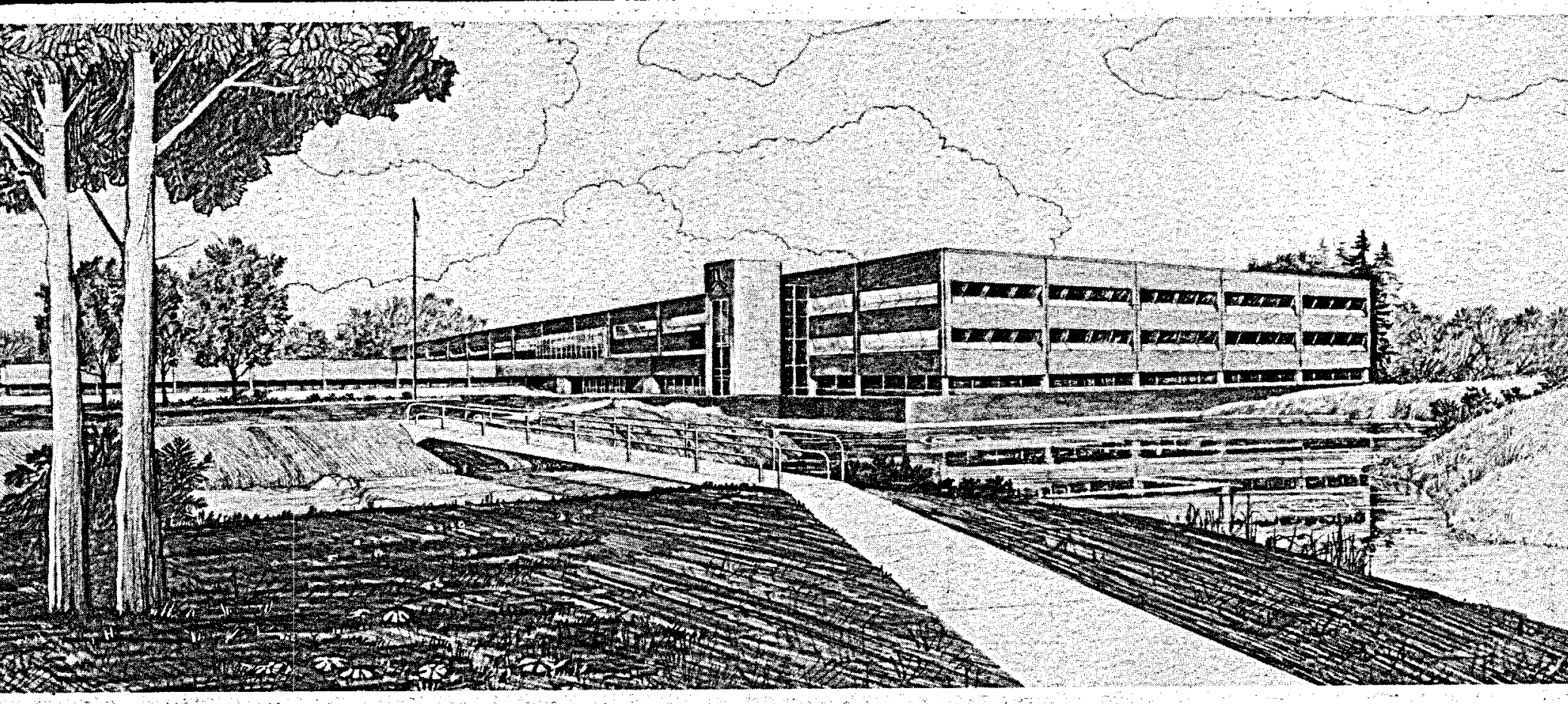

This is an informal report intended for use as a preliminary or working document

Prepared for the

U.S. Department of Energy

Idaho Operations office Under

DOE Contract No. DE-AC07-76ID01570 


\section{DISCLAIMER}

This report was prepared as an account of work sponsored by an agency of the United States Government. Neither the United States Government nor any agency Thereof, nor any of their employees, makes any warranty, express or implied, or assumes any legal liability or responsibility for the accuracy, completeness, or usefulness of any information, apparatus, product, or process disclosed, or represents that its use would not infringe privately owned rights. Reference herein to any specific commercial product, process, or service by trade name, trademark, manufacturer, or otherwise does not necessarily constitute or imply its endorsement, recommendation, or favoring by the United States Government or any agency thereof. The views and opinions of authors expressed herein do not necessarily state or reflect those of the United States Government or any agency thereof. 


\section{DISCLAIMER}

Portions of this document may be illegible in electronic image products. Images are produced from the best available original document. 
EGG-GTH-5002

\title{
Crane Creek Known Geothermal Resource Area:
}

An Environmental Analysis

\author{
Susan G. Spencer \\ Brent F. Russe11 \\ Editors
}

September 1979

EG\&G Idaho, Inc.

\section{Idaho Falls, Idaho 83401}

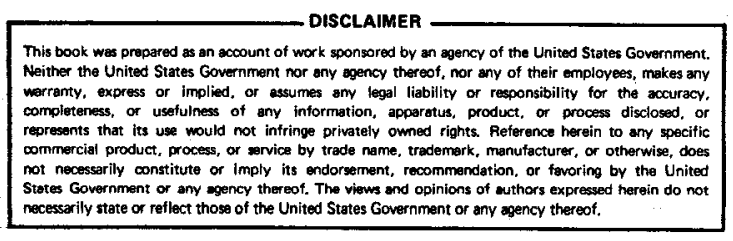




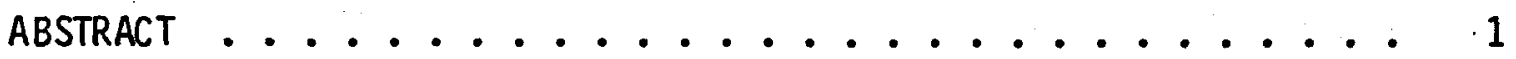

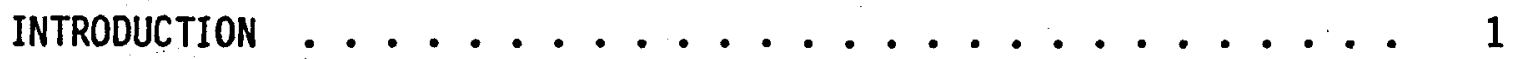

EVALUATION OF THE ENVIRONMENT ............... 3

Physical Environment ................... 9

Climate and Meteorology ............ 9

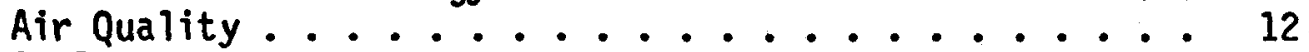

Geology ..................... 12

Subsidence ................... 15

Seismicity ............... . . 17

Water Resources . . . . . . . . . . 22

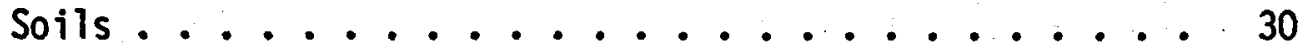

Biological Environment .............. 37

Terrestrial Ecology ............... 37

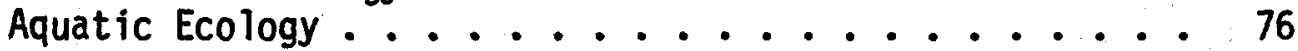

Human Environment ..................... 79

Demography .................... 79

Socioeconomics ................. 87

Heritage Resources ............. 100

REFERENCES ....................... 108

APPENDIX A -- SNAKE RIVER BASIN OVERVIEW REPORTS AND

SUPPORTING DOCUMENTS ............................ 115

\section{FIGURES}

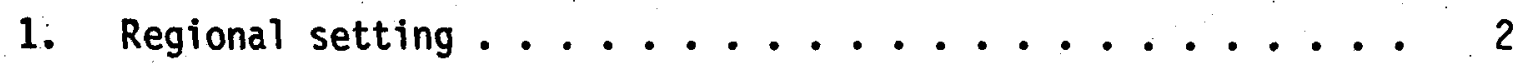

2. Crane Creek KGRA .................... 4

3. Topographical map of Crane Creek KGRA .......... 5

4. LANDSAT photograph of Crane creek ........... 6

5. Crane Creek KGRA .................. 7

6. Crane Creek Hot Springs .............. 8 
7. Historical seismicity from U.S. Coast and Geodetic Survey (NOAA) 1880 - 1975. KGRAs are noted on map: MH - Mountain Home, B - Bruneau, CC - Cast le Creek, CRC - Crane Creek,

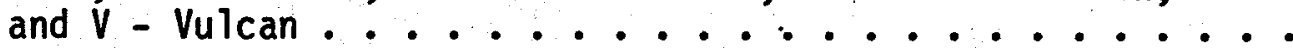

8. Seismicity for 1976 - 1977 from B.S.U. network. KGRAs are noted on the map: MH - Mountain Home, B - Bruneau, CC Cast le Creek, CRC - Crane Creek, and V - Vulcan ....... 21

9. Crane Creek Basin and Crane Creek KGRA ............ 23

10. Characteristic monthly runoff at the mouth of Crane Creek near We iser (source: HISARS Record, Univeristy of Idaho) • . 26

11. Characteristic monthly runoff of Crane Creek below reservior near Midvale .............. 27

12. Groundwater contour map .............. 28

13. Known water rights in the Crane Creek KGRA ........ 33

14. Location of Soil Conservation Service soil survey

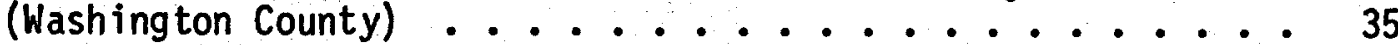

15. Areas in Crane Creek KGRA of high environment sensitivity due to erosion hazards (BLM soil survey, 1976) (legend

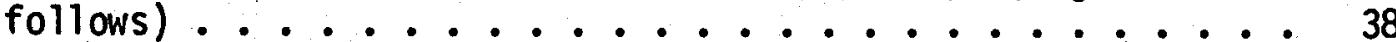

16. Relative extent of the Tall Sagebrush vegation habitat (shaded area) within the Crane Creek KGRA and its associated non-competitive lease application area

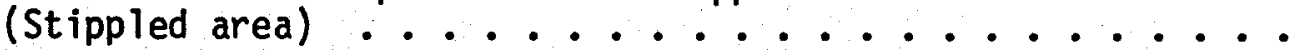

17. Recorded distributions of threatened and endangered plant species in Washington County. Note: This figure is followed by six pages of specific information concerning these species. Species included are: Eriogoum thymoides, Primula cusickiana, Haplopappus radiatus, Trifolium plumosum amplifolium ...............

18. Distribution of Mule Deer (Odocoileus hemionus) wintering habitat within Washington County, Idaho, generally illustrating its proximity to the Crane Creek KGRA .......

19. Distribution of Elk (Ceruus Canadensis) habitat within Washington County, Idaho, generally illustrating its proximity to the Crane Creek KGRA

20. Distributions of Black Bear (Ursus americanus) habitat (cross-hatched) and Pronghorn (Antilocarpa americana) habitat (horizontal lines) within Washington County, Idaho, generally illustrating its proximities to the Crane Creek KGRA ..... 
21. Distribution of California Quail (Lophortyx californicus) habitat (cross-hatched) and Mountain Lion (Felís concolor) habitat (horizontal lines) within Washington County, Idaho, generally illustrating their proximities to the Crane Creek KGRA ......................

22. Distribution of Chukar (Alectoris chukar) habitat within Washington County, Idaho, generally illustrating its proximity to the Crane Creek KGRA .......... 69

23. Distribution of Sage Grouse (Centrocercus urophasianus) habitat (cross-hatched) and its known strutting grounds (stippled) with in Washington County, Idaho, generally illustrating their proximities to the Crane Creek KGRA .... 70

24. Distributions of Bald Eagle (Haliaectur leucocoephalus) wintering habitat (double lines), wild Turkey (Meleagris gallopavo) habitat (cross-hatched) and waterfow reproduction habitat (horizontal lines) within Washington County, Idaho ..

25. Distributions of White-faced Ibis (Plegadis chini) habitat (horizontal lines), Sharp-tailed Grouse (Pedioecetes phasianellus) habitat (cross-hatched) and Prairie Falcon (Falco mexicanus) habitat (veritcal lines) with in Washington County, Idaho, generally illustrating their proximities to the Crane Creek KGRA ..............

26. Distribution of Idaho Ground Squirrel (Spermophilus brunneus) with in Washington County, Idaho, generalTy illustrating its proximity to the crane creek KGRA ........

27. Percentage composition for total fish, game fish, and nongame fish in the electrofishing sample; Weiser River (Starkey downstream to the mouth at the Snake River), August 27 to September $10,1974 \ldots \ldots$

28. Stuart's and Hunt's routes across southern Idaho (Rollins

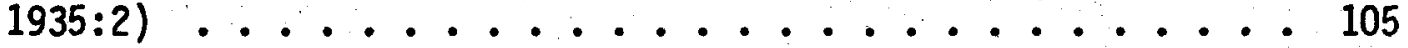

29. John Work's route across central Idaho . . . . . . . 106

\section{TABLES}

1. Analysis of Water Chemistry - Crane Creek Hot Springs $11 \mathrm{~N}-3 \mathrm{~W}-7 \mathrm{BDBIS}$ (in $\mathrm{mg} / 1$ un less otherwise noted) ...... 10

2. Surmary of Climatic Conditions ............ 11

3. Hydrologic Records for the Crane Creek Drainage Basin .... 25

4. Crane Creek Water Quality Data ............ 29 
5. Crane Creek Groundwater Quality Data ........... 31

6. Basic Data Table of Chemical Analyses of Water From

Selected Wells and Springs in the Weiser River Basin .... 32

7. Water Rights Information for the Crane Creek KGRA Area .... 34

8. Relative Abundance and Habitat Listings for Amphibians

in the Crane Creek KGRA ...................... 49

9. Relative Abundance and Habitat Listings for Reptiles in

the Crane Creek KGRA .............. 50

10. Relative Abundance and Habitat Listings for Birds in the

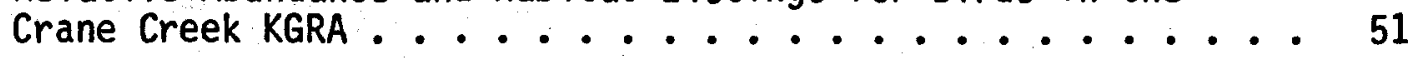

11. Relative Abundance and Habitat Listings for Mammals in the

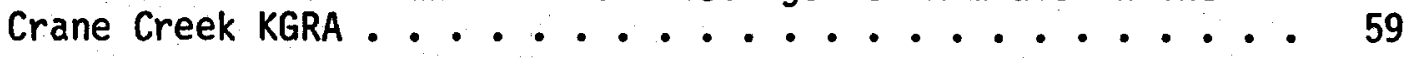

12. Special Concern Species of the KGRA ........... 62

13. Est imated Percentage of Migrating Ducks, Geese and Swans that Fly Over the KGRAs Annually........... 75

14. Weiser River Benthos ............... 78

15. Population Change, 1970-1976 Area: Washington County ... 80

16. Sumary Characteristics of the Population, 1970

Area: Washington County ............ 81

17. Population and Employment Forcast, 1978, Washington County . 82

18. Sumary Education Data Area: Washington County . . . . . 84

19. Name, Enrollment, and Location of Schools Near KGRA, 1977-1978 Area: Crane Creek KGRA (Washington County) . . 85

20. Crime Frequencies and Rates per 100,000 Population, 1971-1976 Area: Washington County ......... 86

21. Labor Force, Unemp loyment, Unemp loyment Rate, and Employment, 1974-1977 Area: Washington County . . . . . 8 88

22. Employment by Type and Broad Industrial Sources, 1971-1976 (Full- and Part-Time), Washington County ..... 90

23. Employment by Type and Broad Industrial Sources, 1971-1976 (Fu11- and Part-Time - Surmary Analytics),

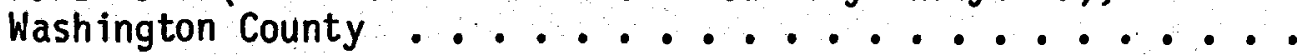

24. Sumary Selected Services Data, 1972 Area: Washington County .................. 
25. Sumary Retail Trade Data, 1972 Area: Washington County ... 93

26. Personal Income by Major Sources, 1971-1976 (Thousands of Doll ars), Washington County ............. 94

27. Personal Income by Major Sources, 1971-1976 (Summary Analytics), Washington County .......... 95

28. General Agricultural Data, 1974 Area: Washington County . . 97

29. Summary Data on Land Use, Land Ownership, and Land-Use Control Mechan isms, 1976-1977 Area: Washington County . . . 98

30. Summary Data on Assessed Value and Property Tax Charges, 1977 Area: Washington County ............ 99 


\section{Crane Creek KGRA}

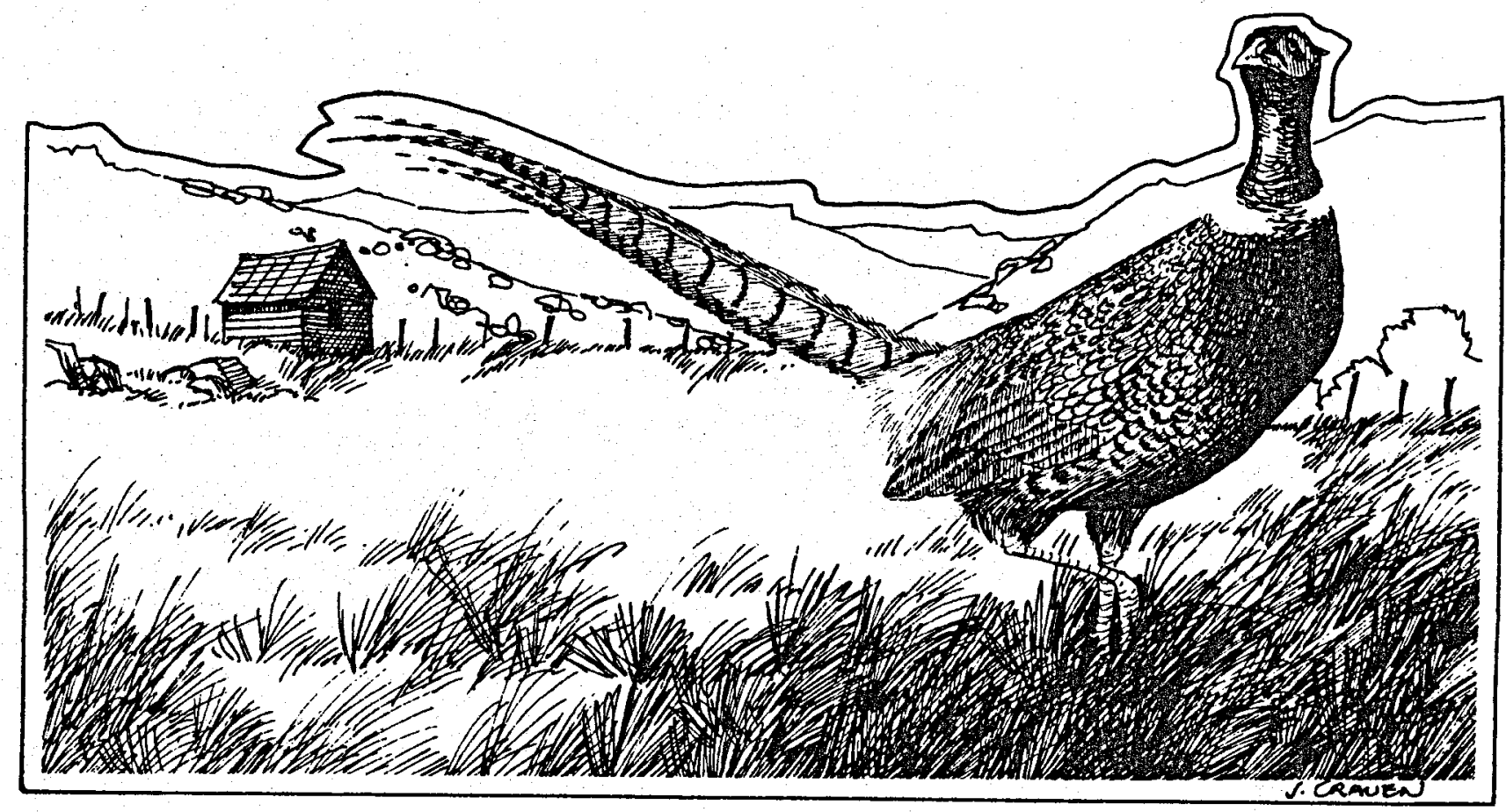




\section{ABSTRACT}

The Crane Creek known geothermal resource area (KGRA) is located in Washington County, in southwestern Idaho. Estimated hydrothermal resource temperatures for the region are $166^{\circ} \mathrm{C}$ ( $\mathrm{Na}-\mathrm{K}-\mathrm{Ca}$ ) and $176^{\circ} \mathrm{C}$ (quartz). The KGRA is situated along the west side of the north-south trending western Idaho Fault Zone. Historic seismicity data for the region identify earthquake activity within $50 \mathrm{~km}$. The hot springs surface along the margin of a siliceous sinter terrace or in adjacent sediments. Approximately $75 \%$ of the KGRA is underlain by shallow, stony soils on steep slopes indicating topographic and drainage $1 \mathrm{imi-}$ tations to geothermal development. Species of concern include sage grouse, antelope, and mule deer. There is a high probability of finding significant prehistoric cultural resources within the proposed area of development.

\section{INTRODUCTION}

EG\&G Idaho, Inc., has completed an environmental analysis for the Crane Creek Hot Springs KGRA as part of a comprehensive preplanning environmental program related to the KGRAs in the Snake River Basin of Idaho. EG\&G Idaho, Inc., is performing the preplanning environmental program under the auspices of the Office of Health and Environmental Research of the U.S. Department of Energy (DOE). KGRAs included under this program (see Figure 1) are Vulcan Hot Springs, Crane Creek, Castle Creek, Bruneau, Mountain Home, Raft River, Is land Park, and Yellowstone. The Crane Creek Hot Springs KGRA is the subject of this report.

The ultimate goal of the preplanning environmental program is to reduce the delays in geothermal development while minimizing environmental impacts by (a) assessing the existing environmental baseline data for the KGRAs, (b) evaluating those data for adequacy and applicability, and (c) developing a plan for supplementing the existing data to achieve a sound environmental data base prior to geothermal development. 


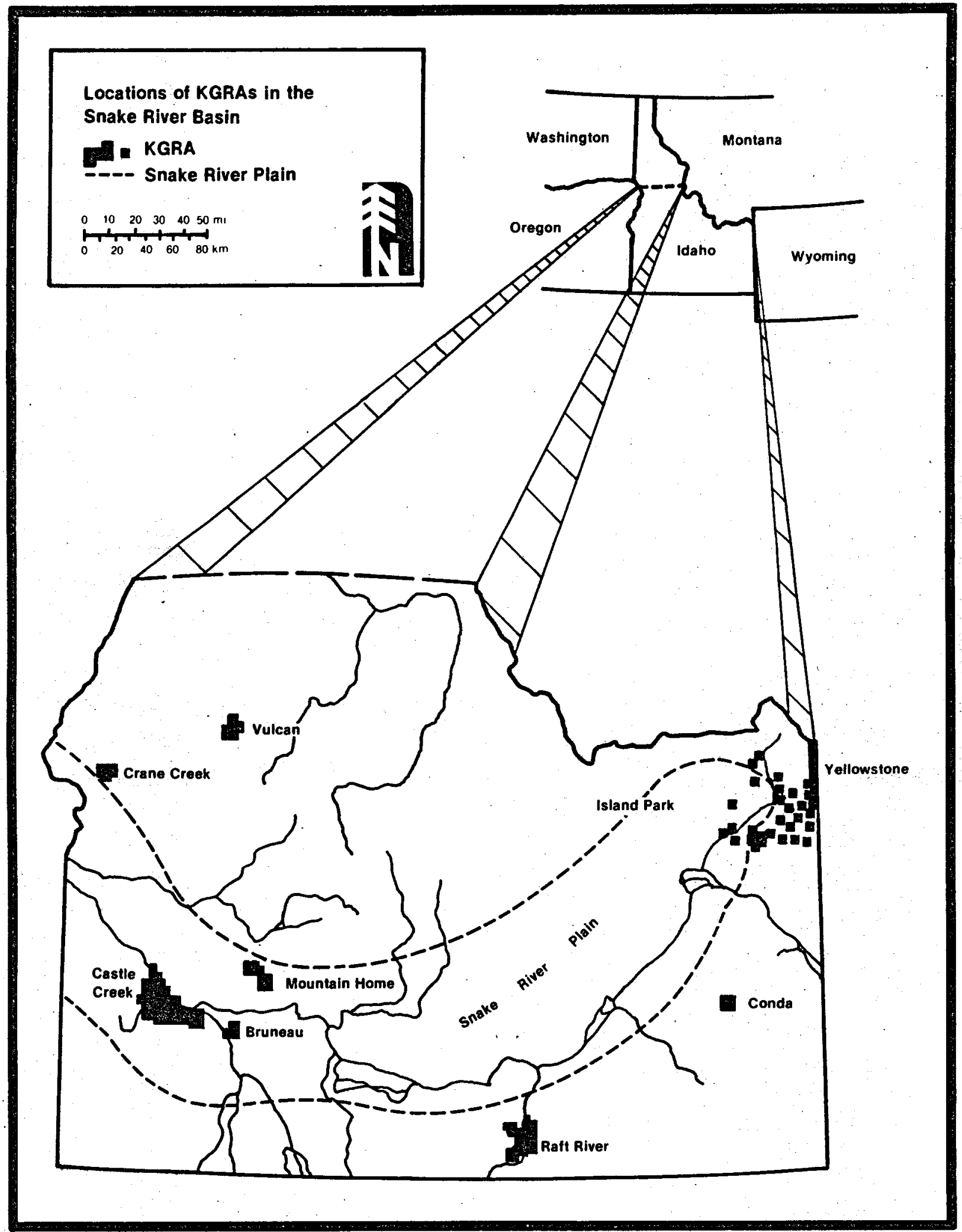

Figure 1. Regional setting. 
Results from the environmental program thus far include a summary of the environmental concerns related to geothermal development in each of the KGRAs ${ }^{1}$, an annotated bibliography of reference materials, detailed reports on the various program elements for each of the KGRAs, a program plan ident ifying future research needs, and a comprehensive data file. These will serve: (a) as planning tools for state and federal energy, environmental, and land management agencies, (b) as reference documents for developers to shorten and simplify project environmental evaluations, and (c) to identify the significant environmental concerns for each KGRA so that mitigation measures can be incorporated early in the development process.

This report includes available environmental information for the Crane Creek Hot Springs KGRA. The information presented is a compilation of the most recent data available for analyzing the physical environment, biological environment, and human environment for this area. The sources providing the data are identified alongside the subject tit les throughout the report. Current comitments and environmental concerns that might affect geothermal development in the region are discussed. Other reports in this series as well as the technical reports which form the basis of this overview are listed in Appendix $A$ and are available from Information Processing in the Information Division at EG\&G Idaho, Inc., P.0. Box 1625, Idaho Falls, Idaho 83401 .

\section{EVALUATION OF THE ENVIRONMENT}

The Crane Creek KGRA is located in Washington County along Crane Creek, which flows west through a steep, narrow canyon and enters the broad Weiser River Valley (Figures 2 through 6). Of the 1757 ha included in the KGRA, 1311 are controlled by the Bureau of Land Management. The remaining 1 ands are privately-owned. Ninety-two percent of the KGRA is utilized as rangeland, while $8 \%$ is irrigated cropland. 
R.AW.

R.3W.

R.2W.

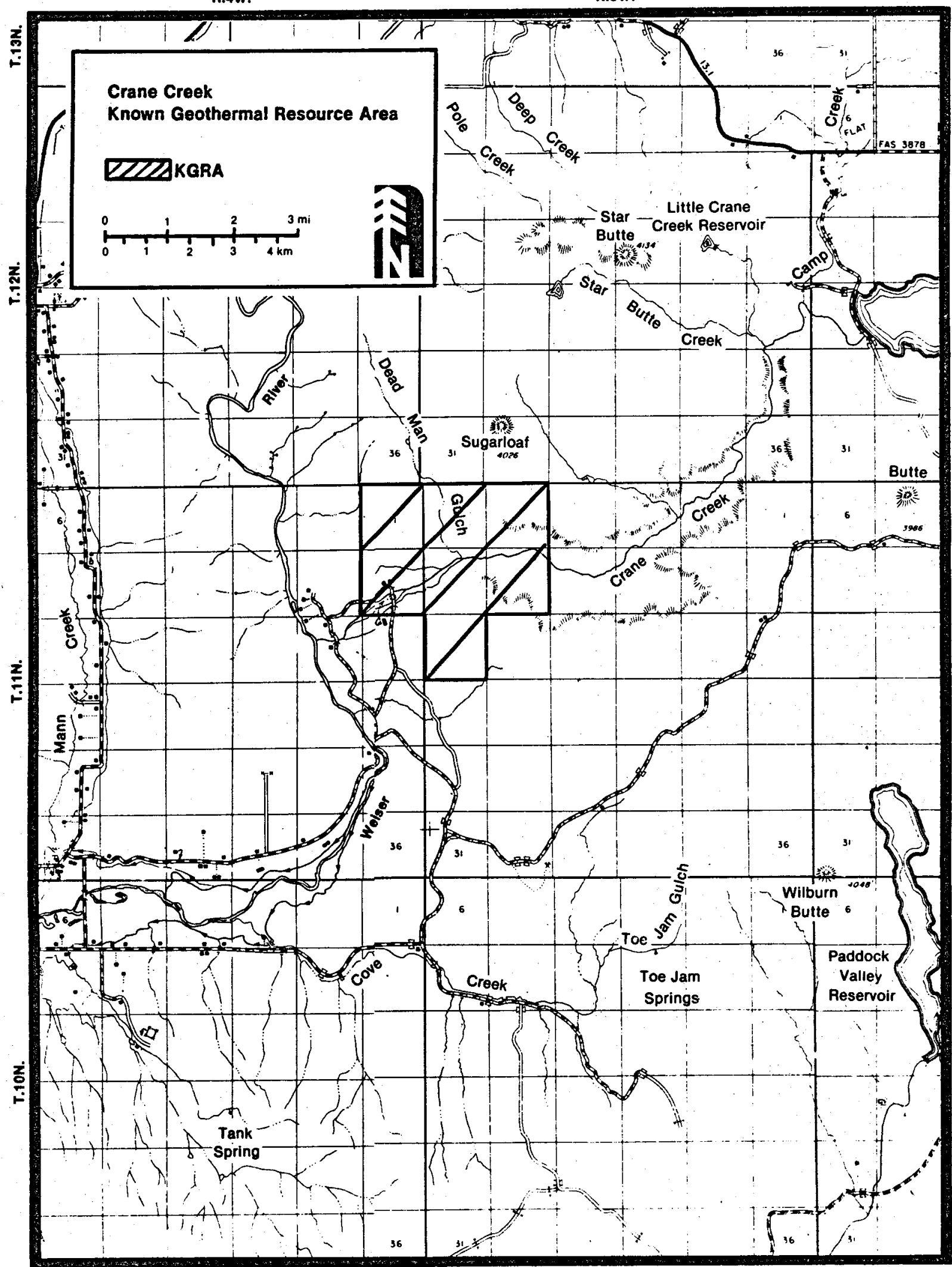

Figure 2. Crane Creek KGRA. 
3. (2)

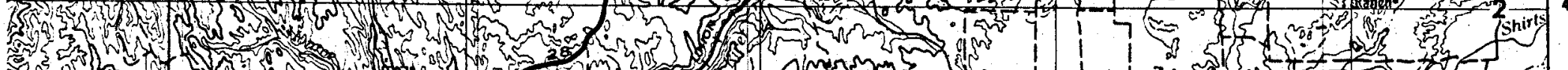
(1) Lis) 3 (3) 2) N 1 N N T(5) (5) 17.

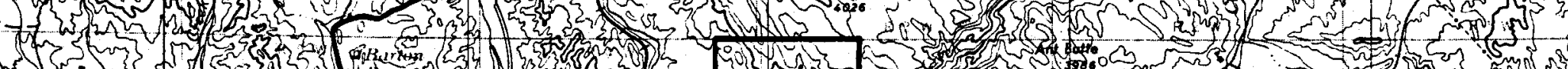
5.0.

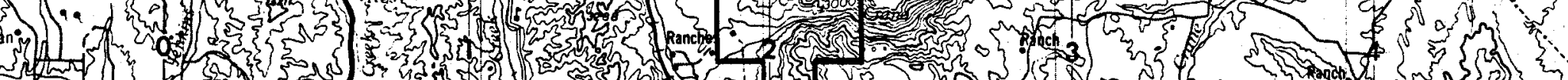

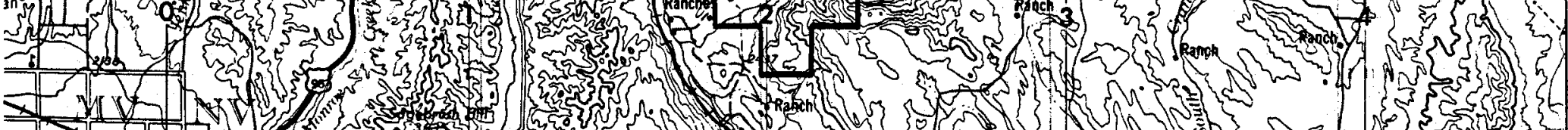
10170 .

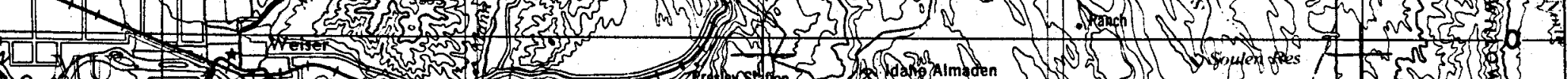
(1)

Figure 3. Topographical map of Crane Creek KGRA. 


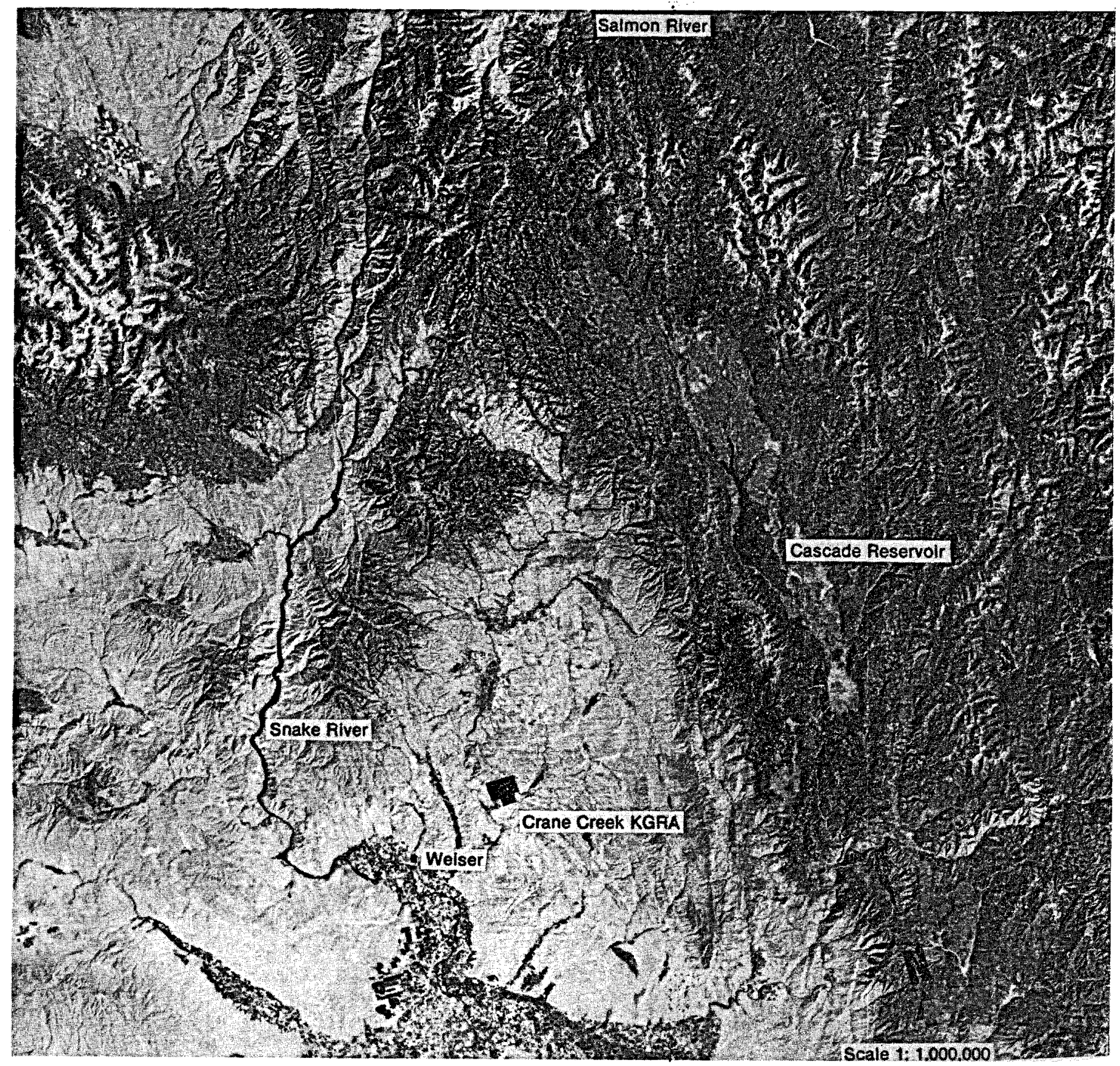

Figure 4. LANDSAT photograph of Crane Creek. 


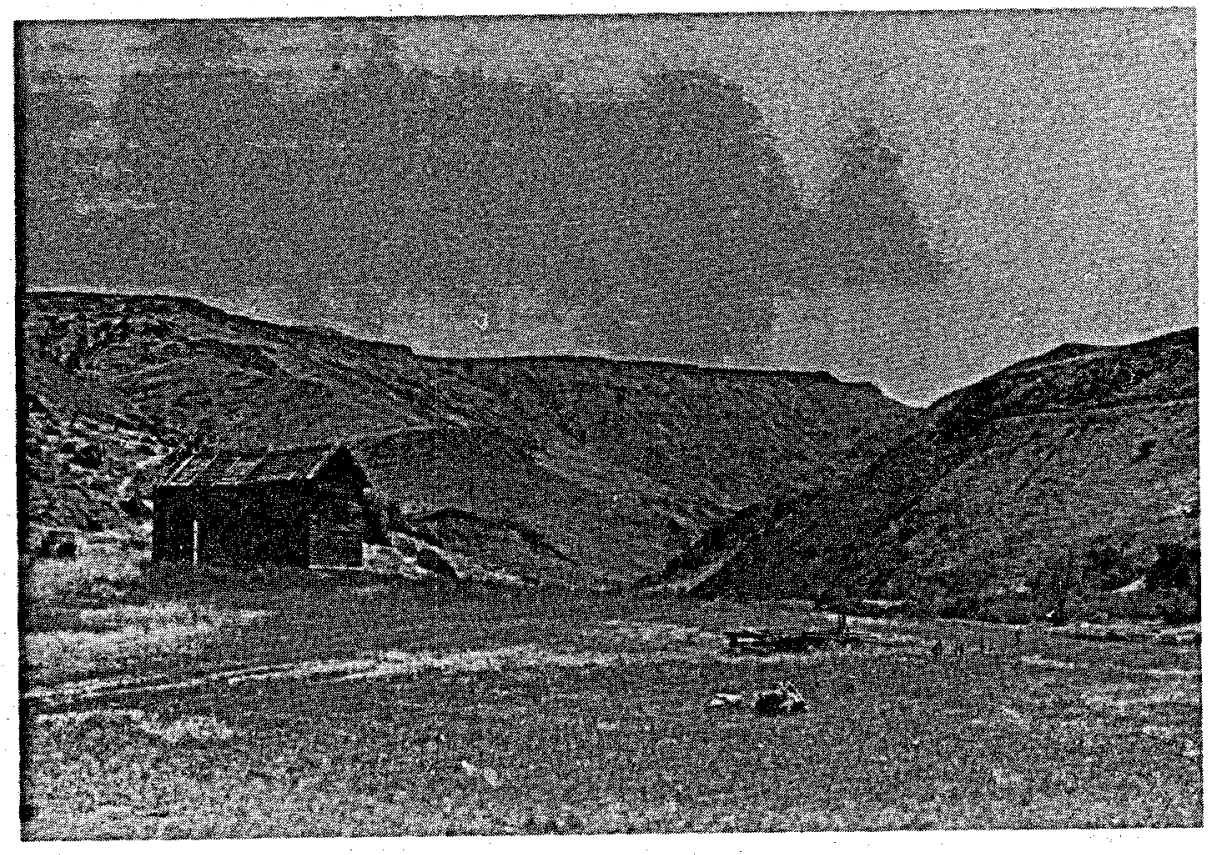

Figure 5. Crane Creek KGRA. 


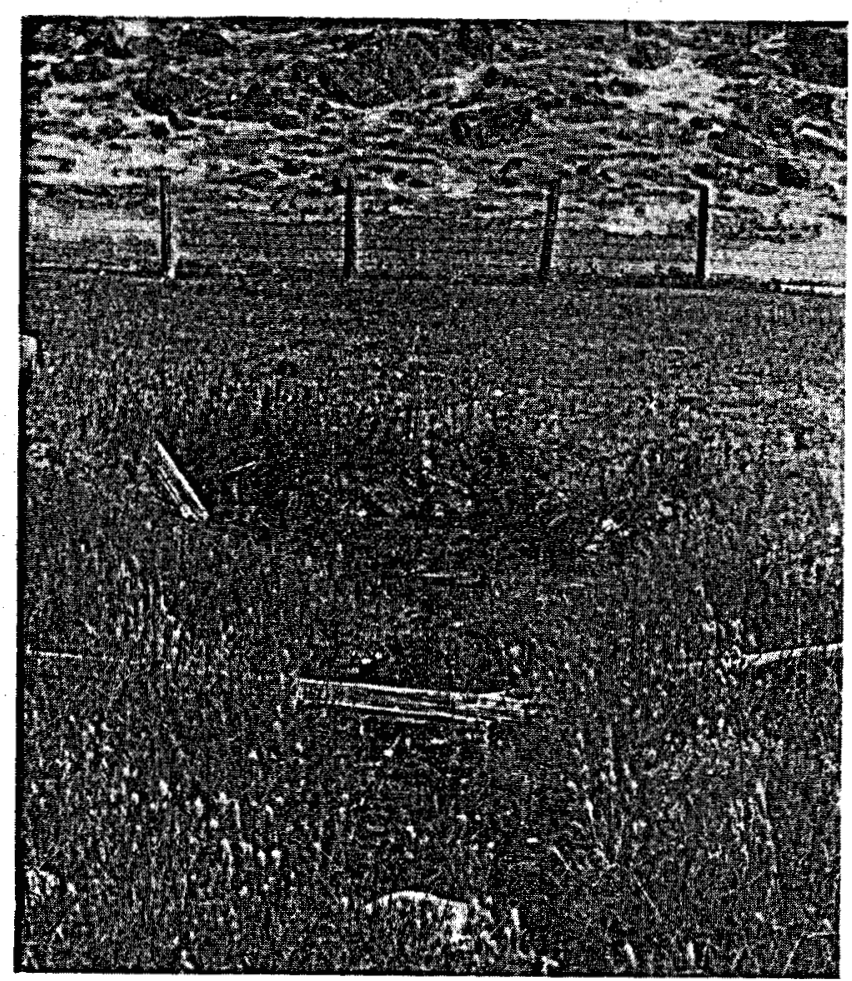

Figure 6. Crane Creek Hot Springs. 
Est imated resource temperatures from the Crane Creek Hot Springs are $166^{\circ} \mathrm{C}(\mathrm{Na}-\mathrm{K}-\mathrm{Ca})$ and $176^{\circ} \mathrm{C}$ (quartz). ${ }^{2}$ Sinter deposits indicate temperatures exceeding $180^{\circ} \mathrm{C}$ at depth. On the basis of the estimated reservoir temperatures, the Crane Creek resource is one of the two hottest resources in Idaho. The Idaho Department of Water Resources has classified the area as a designated geothermal resource area, therefore, any drilling in excess of $900 \mathrm{~m}$ requires a geothermal drilling permit from the State. The hot springs are located on the east side of a fault zone and may be controlled by a deep-seated basement fault. The springs surface along the margin of a siliceous sinter terrace or in adjacent sediments. A chemical analysis of the geothermal fluids in shown in Table 1.

\section{Physical Environment}

The evaluation of the physical environment of the Crane Creek KGRA includes climate and meteorology, air quality, geology, subsidence, seismicity, and water resources; these are discussed in detail in the following subsections.

\section{Climate and Meteorology (M. Delisio, GeoTechniques)}

No primary meteorological data exist for the Crane Creek KGRA. Data on climate and meteorology included in this report are extrapolated from several sources $3,4,5,6$ and are provided as an estimate of existing conditions (Table 2). The average annual temperature at Weiser, the nearest weather station, is $10.7^{\circ} \mathrm{C}$. The average rainfall at Weiser is $533 \mathrm{~mm}$ and the mean annual snowfall is $610 \mathrm{~mm}$.

The area is in the zone of prevailing westerlies and polar easterlies wind systems; the contact of the two form fronts and generate the clouds and associated weather activity that occur. Most of the cool air consequent with frontal activity is maritime polar air from the Pacific Ocean while some is the result of continental polar air from interior Canada. 
TABLE 1. ANALYSIS OF WATER CHEMISTRY - CRANE CREEK HOT SPRINGS $11 N-3 W-7 B D B 1 S$

(in $\mathrm{mg} / \mathrm{l}$ unless otherwise noted)

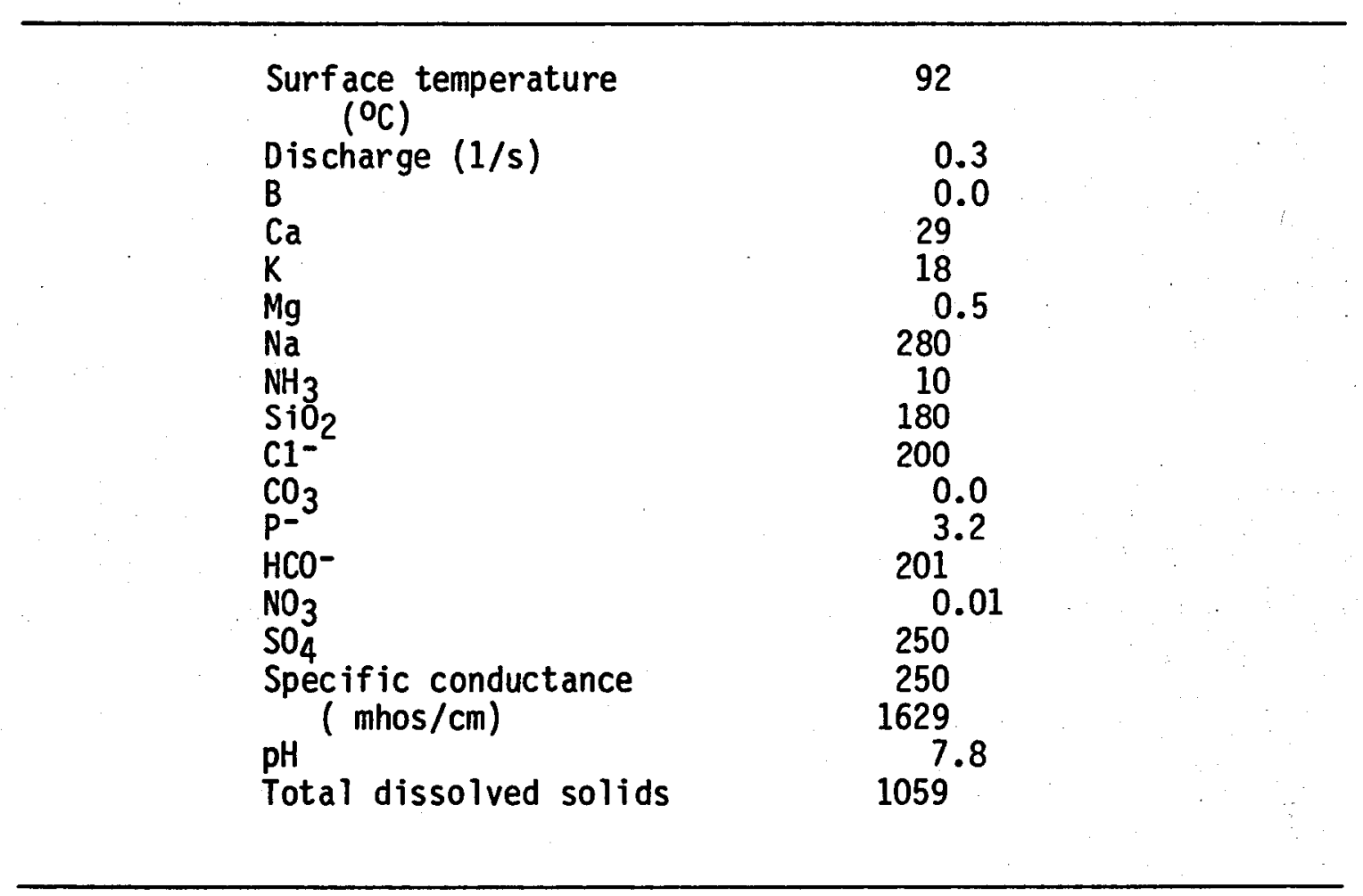


TABLE 2. SUMMARY OF CLIMATIC CONDITIONS

Temperature $\left(^{\circ} \mathrm{C}\right)$

\section{7}

Precipitation (mm)

total annual 1143

Wind

$$
\begin{aligned}
& \text { (no surface data available) } \\
& 850 \mathrm{mb} \text { level airflow } \\
& \text { Spring - W } \\
& \text { Summer - W to NW } \\
& \text { Autumn - SW } \\
& \text { Winter - S to SW }
\end{aligned}
$$

Stagnation (\%)

Surmer: Night-time windspeed $11 \mathrm{~km} / \mathrm{h}$ or less - $60 \%$ Inversion based $150 \mathrm{~m}$ or less above ground - 37\%

Autumn: Night-time windspeed $11 \mathrm{~km} / \mathrm{h}$ or less - $50 \%$ Inversion based $150 \mathrm{~m}$ or less above ground - 53\% 
Damaging storms occur infrequently; most are associated with thunderstorms or a fast moving cold front. Hail damage occurs less than $1 \%$ of the time in any month.

Air Quality (E. Bentley, GeoTechniques)

Air quality data are extrapolated from that collected at Weiser by the Environmental Protection Agency and the Idaho Department of Health and Welfare. Crane Creek KGRA is isolated from the major population center at Weiser by a distance of $48 \mathrm{~km}$. Air circulation from Weiser tends to be southeasterly and away from the KGRA; therefore, conditions in Washington County are not represented by conditions in Weiser. Overall, the county exceeds primary standards for particulate matter. Two sources of pollutants have been identified in the county; both are located in Weiser. Petty Redimix and Weiser Feed and Storage generate $2032 \mathrm{~kg}$ and $4064 \mathrm{~kg}$, respectively, per year. No data are available for sulfur dioxide, nitrous oxides, hydrocarbons, or carbon monoxide.

The Crane Creek geothermal site encompasses a deep canyon that is geographically isolated from any major population centers; therefore, the impact on air quality in these areas by geothermal development will be minimized. Due to the physical geography of the area, gravity winds are a problem in the fall and spring of the year. During the evening hours, down-canyon movement of cool air can be expected and fog generated at the geothermal site could be carried as far west as the city of Weiser. Any plans for geothermal development in this area should consider this problem.

Geology (R. Hardyman, GeoTechniques)

The Crane Creek KGRA is located along the west side of the north-south trending, Western Idaho Fault Zone that in part separates the Idaho Batholith to the east from the Payette Basin to the west. Cretaceous Idaho Batholith rocks are exposed approximately $20 \mathrm{~km}$ east 
of the KGRA. 01der Mesozoic and Paleozoic metavolcanic and metasedimentary rocks are exposed approximately $11 \mathrm{~km}$ northwest of the KGRA. These rocks and perhaps Cretaceous Idaho Batholith rocks are believed to form the basement complex under the Crane Creek KGRA.

The surficial geology in the Crane Creek KGRA consists of rocks ranging in age from Miocene to Holocene. Most of the exposed bedrock in the KGRA consists of basalt to latite lava flow rock or volcaniclastic sedimentary and arkosic sandstones of Miocene age. The sedimentary rocks overlie the lavas in angular unconformity. The existence of sedimentary rocks of Pleistocene age has not been confirmed in the Crane Creek KGRA area. The youngest deposits in the area consist of landslide debris (minor) and surficial alluvium deposits of the Holocene age.

The oldest rocks in the Crane Creek KGRA are lava flow rock and interbedded volcaniclastic sedimentary rocks of Miocene age. Lava flows consist primarily of nonporphyritic fine-grained or ophitic olivine-bearing basalts. Some nonporphyritic flows of andesite or latite composition are also locally present in the sequence. Lava flows are generally $15 \mathrm{~m}$ or less in thickness and are commonly separated by thin layers of basaltic clinker material, fine-grained basaltic ash, rarely silicic vitric tuff, or pumice lapilli tuff. The exact stratigraphic relationship of these lavas to Columbia Plateau Basalts, mapped regionally to the west and northwest of the Weiser area, is uncertain. The aggregate thickness of the lava flows in the KGRA may be as much as $300 \mathrm{~m}^{7}$

Younger Miocene sedimentary rocks unconformably overlie the basalt flows in and to the west of the KGRA. Fine-grained volcaniclastic rocks and coarse-grained arkosic sandstone are the dominant lithologies in these sediments. Locally, thin beds of flood-plain deposits rich in plant debris and thin lignite layers are present. Most of the sandstone exposed in the KGRA is silica-cemented and the rocks crop out in ledge-forming layers. A cobble conglomerate con- 
taining porphyritic, plagioclase-bearing igneous rock of unknown provenance occurs north of Crane Creek. Minor thin beds of tuff (commonly altered to clay) and well-sorted lacustrine silts occur in the sedimentary section. The sedimentary section may be as much as $200 \mathrm{~m}$ thick in areas south of the KGRA. Combined thickness of the rocks in the KGRA is uncertain.

The basalt flows in the KGRA and vicinity generally dip 5 to $15^{\circ}$ to the east-northeast. Locally, south of the KGRA, the lavas are tilted to $20^{\circ}$ to the southwest by rotation on normal faults that are downthrown to the northeast. Dips of the overlying sedimentary rocks are variable but dips to the north-northeast are comon. Locally, small shallow folds are present in these sediments . West of the KGRA (west of Mann Creek). Some of the variable dips in these sediments may be due to vertical readjustments on buried faults in the underlying basalts.

The dominant structures in the Crane Creek KGRA are a series of north-northwest trending high-angle (apparently) faults that form a narrow structural zone that trends across lower crane creek and parallel to the Weiser River in the KGRA. Apparent displacement on these faults is commonly down-to-the-east but some down-to-the-west displacements are present. The amount of vertical separation across these faults is uncertain due to the lack of stratigraphic correlation of lava flows across the various faults.

The northwest-trending fault zone crossing the lower Crane Creek area is approximately $5 \mathrm{~km}$ wide. This fault zone coincides with a steep gravity gradient that is suggestive of a major structure in basement rocks at depth. ${ }^{7}$ Hot springs along Crane Creek are located on the east side of the fault zone and may be related to hot water rising along a deep-seated basement fault and into younger faults in the overlying lavas. The overlying sandstones are fractured and 
displaced by minor faults. Small faults in the sediments may have resulted from continued movement on older faults in the underlying lavas or from subsidence related to hot spring activity. The hot springs in the Crane creek area are located along the margin of a siliceous sinter terrace or in adjacent sediments veneering part of a sinter apron. 8

An erosional surface was cut into pre-Tertiary metavolcanicmetasedimentary and perhaps granitic batholith rocks in the Crane Creek area in early Tertiary time. This surface was subsequently buried by a series of Miocene lavas of basaltic to latitic composition that are apparently stratigraphically correlative with Columbia Plateau Basalts further to the west. The basaltic rocks may conceal a major structural discontinuity in the pre-Tertiary basement rocks. Post-Miocene faulting of the lava sequence generally predated deposition of the overlying unconformable continental sedimentary rocks. Faulting may, in part, have been contemporaneous with deposition of the older part of these sediments, but fault activity was apparentiy subdued during deposition of most of the sedimentary rocks. These sedimentary rocks and related faults are apparently unrelated to subsidence of the Western Snake River Plain.

Subsidence (J. Applegate, GeoTechniques)

Subsidence of the ground surface associated with the production of fluids (petroleum and water) has been documented in many areas of the world. A significant number of these areas are in the American West and include Houston, Texas; portions of southern Arizona; Las Vegas, Nevada; the Wilmington and Inglewood oil fields of southern California; the San Joaquin Valley of California; the South Bay area near San Jose, California; and the Raft River Valley of Idaho. Generalized criteria can be established from assessing these areas where subsidence has occurred. The areas of subsidence generally occur where there are youthful, relatively-unconsolidated sedimentary rocks 
of Cenozoic age. ${ }^{9}$ These rocks are of lacustrine and/or alluvial origin and include interbedded coarse-grained and fine-grained rocks. The permeable sands tone and/or gravel aquifers have low compressibility and are interbedded with clayey aquitards of low permeability, high compressibility, and variable thickness. The withdrawal of fluids causes a decrease in the hydrostatic head of the aquifers and in turn causes a transfer of additional load to the matrix (grain-tograin load). The effect results in small amounts of generally elastic compaction in the coarse-grained aquifer and much larger amounts of inelastic compaction in the fine-grained aquitard. In the aquitard, the increase in effective stress results in a dewatering of the clays. ${ }^{10}$ Montmorillonite is the common clay mineral in many of the previously cases of subsidence ${ }^{9}$ and has the ability to lose large volumes of water.

Withdrawal of fluids appears to be the most likely subsidence mechan ism in the KGRAs under study. However, two other potential mechanisms that should be assessed are hydrocompaction and tectonicrelated subsidence.

Hydrocompaction is subsidence due to the collapse of the soil structure of certain moisture-deficient deposits when these deposits lose their dry strength due to wetting. ${ }^{11}$ Hydrocompaction is a one-time process where excess moisture penetrates below the root zone into mo isture deficient material. The process may continue to intensify as the water percolates downward and deeper deposits become wetted.

Tectonic subsidence is subsidence, or uplift, that is related to active tectonic processes within the earth such as movement along faults, ase ismic movement, or emplacement of igneous bodies. As with subsidence related to fluid withdrawal, tectonic subsidence is best observed with repeated leveling; however, these data are extremely limited. There is some documentation of tectonic movements of $0.067 \mathrm{~m}$ in the Raft River Valley, Idaho. ${ }^{12}$ 
Groundwater production in the Crane Creek KGRA is generally from Quaternary alluvium and sandy units in the Idaho Group. From a cursory examination, the groundwater production does not appear to be as high in volume as other areas associated with the Snake River Plain. A factor of interest may be the source of the thermal water at depth. Does the water represent meteoric water that has fallen on the uplands to the north and circulated downward to reasonable depths to be heated or does it represent significantly older water that is upwelling from units deep within the Snake River downwarp. This question would be important in assessing the recharge and water level problems with deep and extensive geothermal production. The shallow Idaho Group rocks appear to be candidates for subsidence and, hence, prompt a careful assessment of the potential subsidence.

Seismicity (J. Applegate, GeoTechniques)

Seismicity studies to determine levels of micro-earthquake activity have been one of the principal exploration tools to define areas of geothermal activity. Many geothermal areas have been found to have large numbers of small earthquakes. The microseismic events have been postulated to be a function of the youthful geologic activities (voicanism and/or faulting) that are associated with geothermal areas. Thus, it is more common than not to find significant seismic activity in close proximity to geothermal systems. However, in this review, the objective is to evaluate the problems associated with seismic activity pertaining to development.

All of the KGRAs in southwest Idaho are in seismic zone II. However, the data base up on which this recommendation was made was somewhat limited. The major problem in the evaluation of seismic risk is that the instrumental seismic data set represents only a limited time period. In the last few years several additional seismic net- 
works have been installed in the State. However, the only two that provide substantial data for this study are the networks surrounding the Idaho National Engineering Laboratory (INEL) and a three-station array in the vicinity of Boise, operated by Boise State University (BSU).

With the limited seismic instrumental data base, other forms of data need to be assessed. The importance of assessing the geological criteria for evaluating seismicity has been emphasized very strongly. by Allen. ${ }^{13}$ These data include indicated active faults (in areas where adequate investigations have been undertaken), evaluation of maps, lineaments, LANDSAT imagery, U-2 photos, and geophysical data including seismic reflection, gravity, and aeromagnetics. These data sets are, of course, not as directly indicative of active seismic zones, but do allow one to more clearly assess potential hazards.

In the portion of southwestern Idaho where the geothermal areas are located, there has been an operating seismograph network since 1975. This network recorded over 800 earthquakes during the period 1976-77. 14 Other available instrumental data come from the INE network (operating since 1971) and from the National Oceanic Atmospheric Administration (NOAA) computer files on earthquake activity for 1880-1975. Numerous workers have published geological reports on areas in southwestern Idaho. The most applicable report and map for this project was a map of active faults in Idaho compiled by Witkind. 7

These data sets may be sufficient to evaluate the general se ismicity of the area, but the limited time span for instrumental data and the small number of observation points does not make the data set applicable for detailed analysis of site specific areas. Geologic studies are generaliy limited in detail and spatial extent to the point that it is quite possible that all of the active faults have not been mapped. 
The Crane Creek KGRA is located in the northern boundary fault zone of the Snake River Plain. ${ }^{7}$ Witkind's map indicates a number of faults which transect the Crane Creek KGRA. ${ }^{7}$ These faults are believed to have last been active in the Late Cenozoic.

The historical seismicity map (Figure 7) shows earthquake activity within $50 \mathrm{~km}$. However, the 1976 to 1977 data (Figure 8) delineate significant seismic activity slightly to the east and north of the area (within approximately $20 \mathrm{~km}$ ). Of these events, one was a magnitude 4.5 in November 1977. A large number of aftershocks were associated with this master event.

No detailed microseismic monitoring studies are available in the immediate area. Proprietary studies exist but these sources are not available. A short term (8-day) study, to evaluate seismicity associated with the Cascade geothermal system in the Cascade area ${ }^{15}$ may shed some light on the activity. The activity was of a swarm nature with essentially no activity recorded during the first seven days and approximately 25 events the last day. The events appeared to be related to an east-west trending structure near the site of the Cascade Dam. Any possible activity at the Crane Creek area could also be of a swarm nature.

The lack of documented seismic activity in the immediate area can not be considered evidence of an aseismic area, but may be indicative of the limited data base. In terms of seismic risk, the 1976 to 1977 activity must be considered as posing significant hazard to proposed development at Crane Creek. Studies by Woodward-Lundgren and Associates (now Woodward-Clyde) ${ }^{16}$ and others 17 indicate that there are geologic features in the area (the Cascade-Sweet zone) of the seismic activity that appear to be youthful when viewed from the air. The possible activity in this area prompted Woodward-Lundgren to 


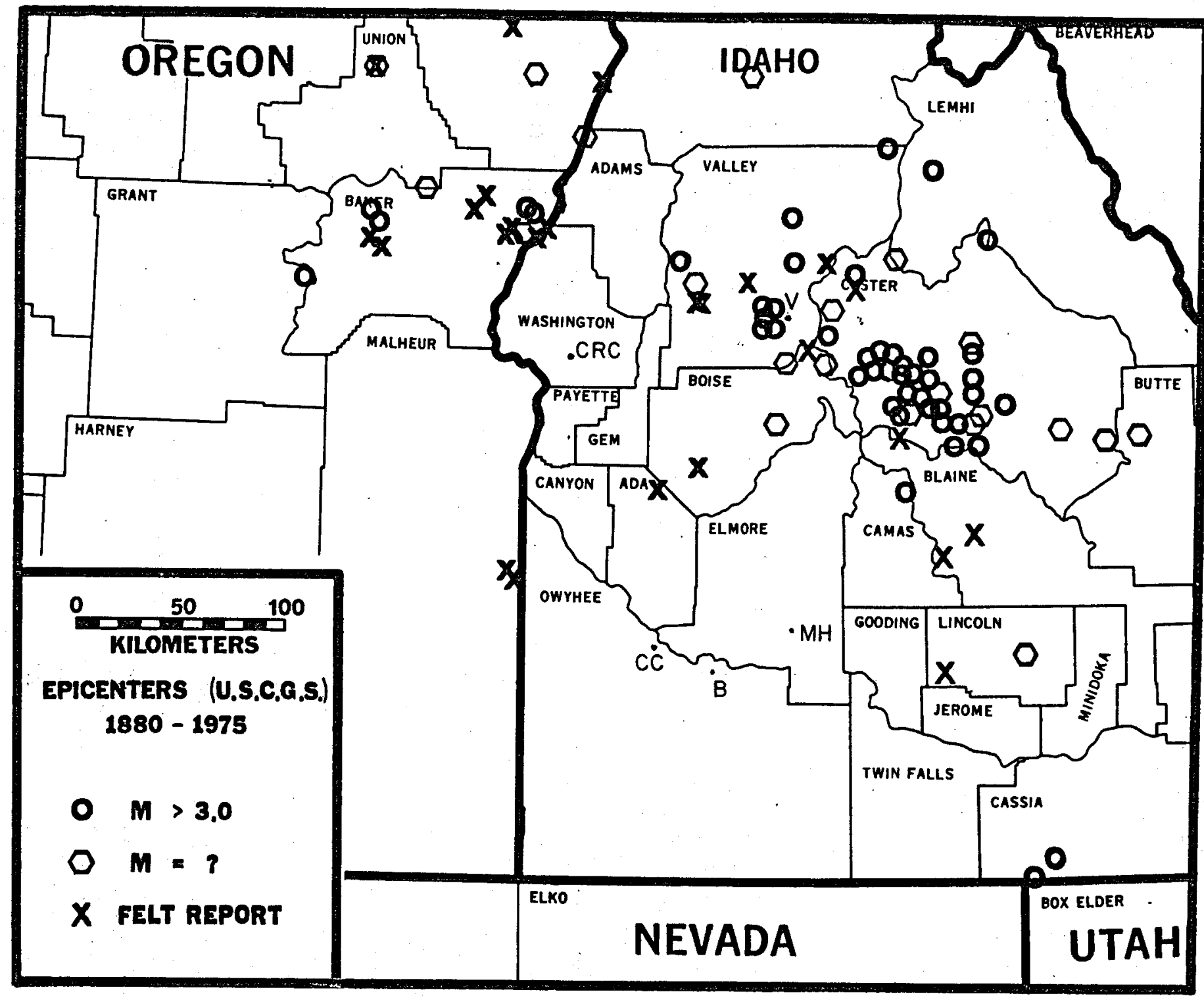

Figure 7. Historical seismicity from U.S. Coast and Geodetic Survey (NOAA) $1880-1975$. KGRAs are noted on map: MH - Mountain Home, B - Bruneau, CC - Cast le Creek, CRC Crane Creek, and V - Vulcan. 


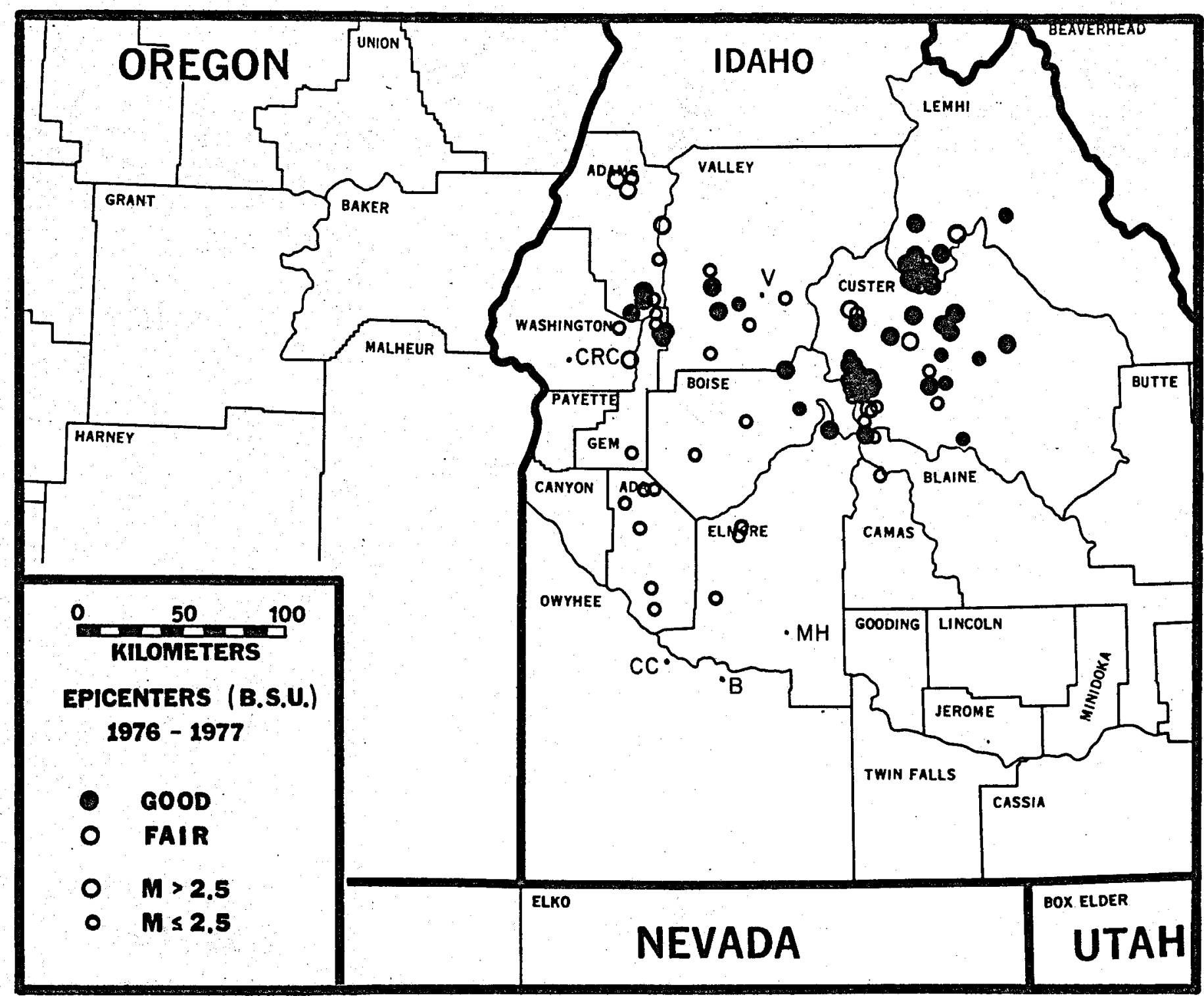

Figure 8. Seismicity for 1976 - 1977 from B.S.U. network. KGRAs are noted on the map: MH Mountain Home, B - Bruneau, CC - Cast le Creek, CRC - Crane Creek, and V Vulcan. 14 
use the lineament as observed from the air (also can be observed on LANDSAT imagery) as the source of the earthquakes which could potentially cause the most damage in the Boise area. These features could generate a magnitude 7.5 earthquake which might produce accelerations in the Crane creek area in excess of $25 \% \mathrm{G}$.

The data available at the present time are insufficient to assess ground rupture or strong shaking resulting from an earthquake immediately within or adjacent to the Crane Creek KGRA. However, there are sufficient data to indicate that potential earthquake sources do exist in the area. These potential earthquake generators warrant detailed geological and seismic studies.

\section{Water Resources}

Hydrology. The primary stream in the KGRA is Crane Creek, which is a tributary to the Weiser River. The drainage area, at the gaging station near the mouth of Crane Creek, is $74563 \mathrm{ha}$. The significant tributaries to Crane Creek are North Crane Creek, South Crane Creek, and Hog Creek. North and South Crane Creeks flow to the north and meet Hog Creek at Crane Creek Reservoir. Crane Creek flows west from Crane Creek Reservoir and meets the Weiser River near Weiser, Idaho. Figure 9 is a general drainage basin map of the area.

The topography of the Crane Creek drainage basin is broken into the flat lands east of Hog Creek, the valleys that are drained by North and South Crane Creeks, and the steep-walled canyon below Crane Creek Reservoir, that opens up into flat land at the mouth of Crane Creek. Elevations in the drainage basin vary from $1580 \mathrm{~m}$ at the headwaters to $680 \mathrm{~m}$ near the mouth of Crane Creek. The KGRA is situated mostly in the canyon below the reservoir and includes a small portion of the flat 1 ands near the mouth of Crane Creek. The agricultural activity on the land near the KGRA consists of cattle grazing and growing forage crops. 
$\tilde{\omega}$

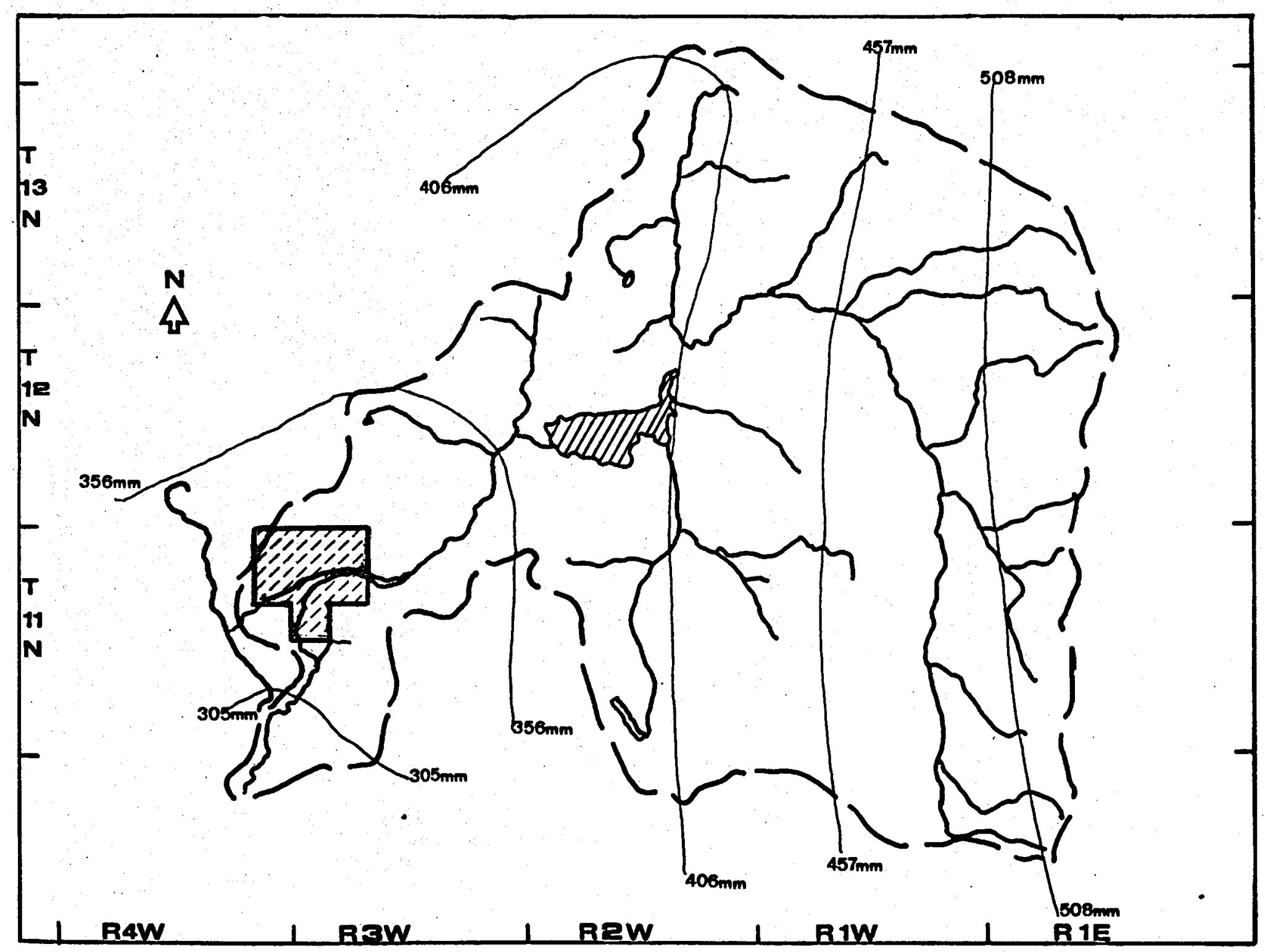

Figure 9. Crane Creek Basin and Crane Creek KGRA. 
The data base for the hydrology of the drainage basin consists of two streamflow measurement records for Crane Creek, rainfall and snowfall records near the drainage basin, and an assessment of the groundwater resources. Table 3 gives information concerning the hydrologic records that form the data base for the Crane Creek drainage basin. The two Crane Creek gaging stations are no longer active; one gage was located at the mouth of Crane Creek, and the other gage was located just below the dam at Crane Creek Reservoir. Figures 10 and 11 show the monthly distribution of runoff for the two streamflow records. Data are also available concerning the flow characteristics of Crane Creek in the Idaho Department of Water Resources Water Information Bulletin Number 44.

The rainfall and snowfall data consist of records at three gaging stations: Weiser, Cambridge, and 01a. Figure 9, the general map of the basin, gives an isohyetal map of the Crane Creek drainage basin that was prepared from maps developed by the U.S. Army Corps of Engineers for a study of the Columbia River Basin.

The Idaho Department of Water Resources conducted a study of the groundwater resources of the Crane Creek drainage basin as part of its evaluation of the water resources of the Weiser River Basin. The data that were collected during the study were reported in Water Information Bulletin Number 44 . Figure 12 is a contour map of groundwater levels in the Crane Creek drainage basin. Measurements were made at several wells in the drainage basin, but there are no long-term observation well records available for the Crane Creek drainage basin.

Water Quality. The surface water quality data base for the Crane Creek drainage basin consists of data found in Water Information Bulletin Number 44 and STORET records obtained from the U.S. Environmental Protection Agency offices in Seattle, Washington. Table 4 presents some of the STORET data for Crane Creek. 
TABLE 3. HYDROLOGIC RECORDS FOR THE CRANE CREEK DRAINAGE BASIN

\begin{tabular}{|c|c|c|c|c|c|c|}
\hline Station & $\begin{array}{l}\text { Type of } \\
\text { Record } \\
\end{array}$ & Latitude & Longitude & Period of Records & $\begin{array}{l}\text { Length } \\
\text { (months) }\end{array}$ & $\begin{array}{l}\text { Annual } \\
\text { Average }\end{array}$ \\
\hline \multirow[t]{4}{*}{ Weiser 2 SE } & \multirow[t]{3}{*}{ Rainfall } & \multirow[t]{4}{*}{$44014 !$} & \multirow[t]{4}{*}{$116057^{\prime}$} & $07 / 1948-05 / 1963$ & 179 & \multirow[t]{4}{*}{$280 \mathrm{~mm}$} \\
\hline & & & & $08 / 1963-09 / 1963$ & 2 & \\
\hline & & & & $11 / 1963-12 / 1976$ & 158 & \\
\hline & Snowfall & & & $11 / 1948-12 / 1976$ & 116 & \\
\hline \multirow[t]{3}{*}{ Cambridge } & Rainfall & \multirow[t]{3}{*}{$44^{\circ} 34^{\prime}$} & \multirow[t]{3}{*}{$116041^{\prime}$} & $01 / 1931-12 / 1958$ & 336 & \multirow[t]{2}{*}{$500 \mathrm{~mm}$} \\
\hline & & & & $02 / 1959-12 / 1976$ & 215 & \\
\hline & Snowfall & & & $01 / 1931-12 / 1976$ & 343 & $1,430 \mathrm{~mm}$ \\
\hline \multirow[t]{2}{*}{$01 \mathrm{a} 4 \mathrm{~S}$} & Rainfall & \multirow[t]{2}{*}{$44008^{\prime}$} & \multirow[t]{6}{*}{$116017^{\prime}$} & $08 / 1951-12 / 1977$ & 317 & $470 \mathrm{~mm}$ \\
\hline & Snowfall & & & $12 / 1951-12 / 1976$ & 123 & $600 \mathrm{~mm}$ \\
\hline \multirow[t]{4}{*}{$\begin{array}{l}\text { Crane Creek } \\
\text { near Midvale }\end{array}$} & \multirow[t]{4}{*}{ Streamf low } & \multirow[t]{4}{*}{$44021^{\prime} 05^{\prime \prime}$} & & $11 / 1910-09 / 1911$ & 11 & \multirow[t]{4}{*}{$65,978,500 \mathrm{~m}^{3}$} \\
\hline & & & & $01 / 1912-09 / 1915$ & 45 & \\
\hline & & & & $01 / 1916-04 / 1916$ & 4 & \\
\hline & & & & $05 / 1924-09 / 1969$ & 545 & \\
\hline $\begin{array}{l}\text { Crane Creek at } \\
\text { mouth near Weiser }\end{array}$ & Streamf low & $44017^{\prime} 28^{\prime \prime}$ & $116046^{\prime} 48^{\prime \prime}$ & $04 / 1921-11 / 1973$ & 632 & $74,690,700 \mathrm{~m}^{3}$ \\
\hline
\end{tabular}

a. Source for these records is HISARS Records, University of Idaho. 


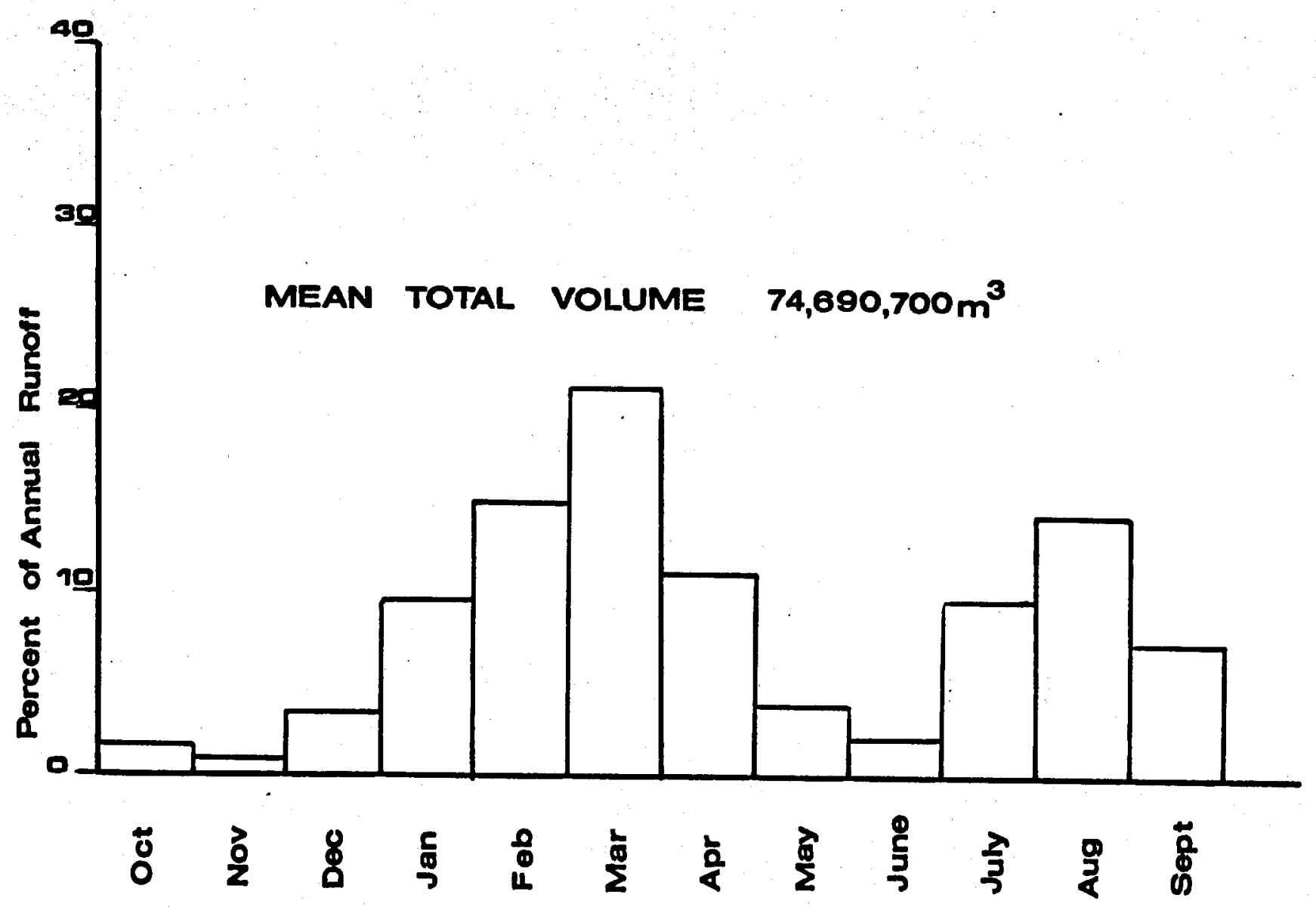

Figure 10. Characteristic monthly runoff at the mouth of Crane Creek near Weiser (source: HISARS Record, University of Idaho). 


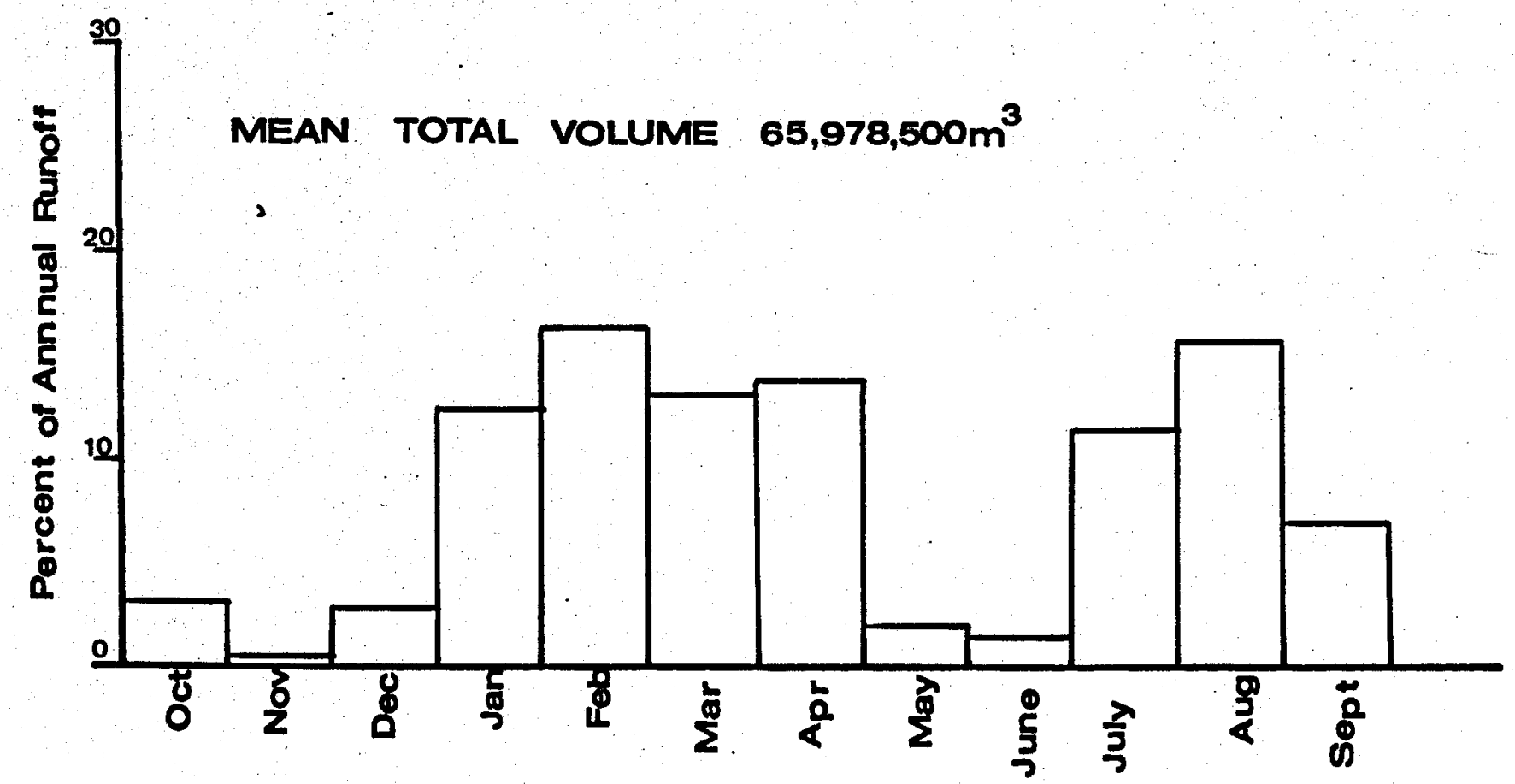

Figure 11. Characteristic monthly runoff of Crane Creek below reservoir near Midvale. 


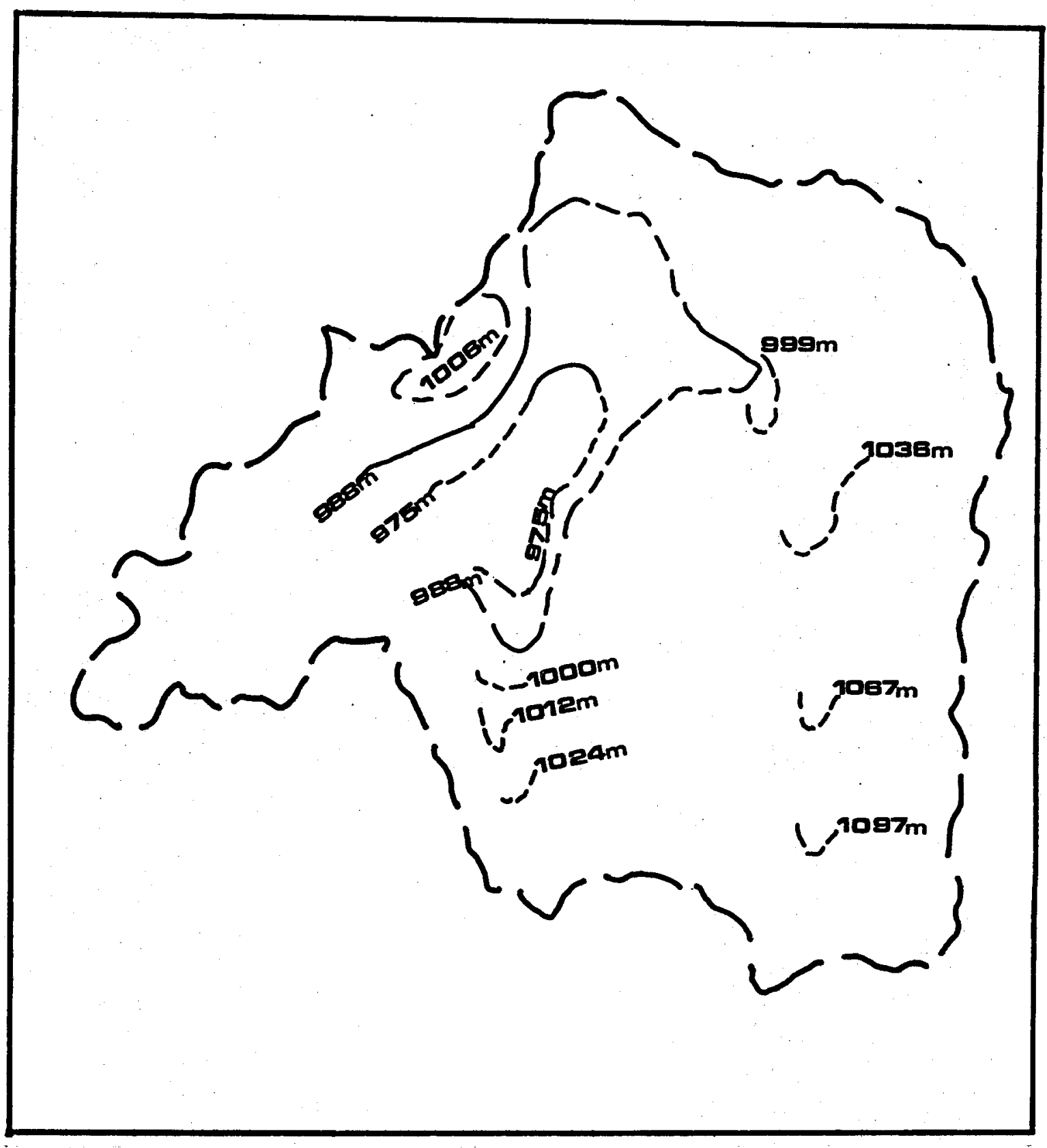

Figure 12. Groundwater contour map. 
TABLE 4. CRANE CREEK WATER QUALITY DATA

\begin{tabular}{|c|c|c|}
\hline $\begin{array}{l}\text { Parameter } \\
\text { Measured }\end{array}$ & $\begin{array}{l}\text { Crane Creek } 26 \mathrm{~km} \\
\text { above Weiser }\end{array}$ & $\begin{array}{l}\text { Crane Creek at } \\
\text { mouth near Weiser }\end{array}$ \\
\hline Water Temperature $\left({ }^{\circ} \mathrm{C}\right)$ & 14 & 12 \\
\hline Streamf low $\left(\mathrm{m}^{3} / \mathrm{s}\right)$ & 3.03 & 5.66 \\
\hline Conductivity ( $\mu$ mhos) & 153.8 & 124.8 \\
\hline Dissolved solids $(\mathrm{mg} / \mathrm{l})$ & 188.0 & -- \\
\hline Dissolved oxygen $(\mathrm{mg} / \mathrm{l})$ & 9.7 & -- \\
\hline Silicon $(\mu \mathrm{g} / 1)$ & 11.0 & - \\
\hline Suspended sediment $(\mathrm{kg} / \mathrm{d})$ & -- & 48484 \\
\hline
\end{tabular}


The groundwater quality data that are available for the Crane Creek Basin are contained in Water Information Bulletin Number 44. Table 5 gives the data for six wells inside the Crane Creek Basin, and Table 6 shows data from the same six wells. The geothermal water quality data are shown in Table 1.

Water Rights. The water rights that are currently held inside the KGRA consist of two licensed surface diversions and a permit well. Figure 13 shows the locations of the diversions, and Table 7 gives information concerning the water rights.

The Crane Creek KGRA demonstrates the best water quality of all the Snake River Plain KGRAs. Most streams and groundwater wells have data available through the STORET program of EPA. These measurements need to be continued and a more intensive program that gives better special representation should be initiated.

There are not many recorded water rights and few decreed water rights so adjudication of all water rights is a definite need. This area of irrigation water rights is administered under State Watermaster District 67.

Soils (N. Savage, Idaho Water Resources Research Institute/N of I)

The Crane Creek KGRA contains both public domain lands administered by the Bureau of Land Management and privately-owned lands. The Washington County Soil Conservation Service (SCS) has completed a detailed soil survey on 89 ha of private lands as indicated in Figure 14. Of these, 16 ha are irrigated, 12 ha are dry cropland, and the remainder are rangeland.

The soils have been mapped on aerial photographs $(1: 20,000)$ and are available on open file at the Weiser office, Washington County SCS. The SCS central office in Boise has on file detailed descriptions of each soil series which include the following data: 
TABLE 5. CRANE CREEK GROUNDWATER QUALITY DATA ${ }^{\mathrm{a}}$

\begin{tabular}{|c|c|c|c|c|c|c|c|}
\hline \multirow{2}{*}{ Well } & \multirow[b]{2}{*}{$\begin{array}{c}\text { Conductance } \\
\text { (umoho) }\end{array}$} & \multicolumn{6}{|c|}{ Concentration (meg/1) } \\
\hline & & $\mathrm{Cl}^{-}$ & $\mathrm{CO}_{3}$ & $\mathrm{SO}_{4}$ & $\mathrm{Na}^{+}+\mathrm{K}^{+}$ & $\mathrm{Mg}^{++}$ & $\underline{\mathrm{Ca}^{++}}$ \\
\hline $11 \mathrm{~N} 2 \mathrm{~W} 16$ AAC1 & 440 & 0 & 4.1 & 0.3 & 1.5 & 1.89 & 1.8 \\
\hline $11 \mathrm{~N} 4 \mathrm{~W} 12 \mathrm{CDCl}$ & 248 & 0.1 & 2.2 & 0.3 & 0.7 & 0.7 & 0.9 \\
\hline $12 \mathrm{~N} 3 \mathrm{~W} 1 \mathrm{CDD} 1$ & 333 & 0.1 & 3.5 & 0.2 & 0.7 & 1.4 & 1.4 \\
\hline $12 \mathrm{~N} 2 \mathrm{~W} 14 \mathrm{DACl}$ & 171 & 0.1 & 1.4 & 0.3 & 0.6 & 0.4 & 0.6 \\
\hline 13 N $2 W 21 \quad D C D 2$ & 700 & 0.4 & 0.9 & 4.7 & 1.0 & 2.1 & 3.2 \\
\hline $13 N 1 W 21$ CDC1 & 193 & 0.1 & 1.6 & 0.2 & 0.7 & 0.5 & 0.7 \\
\hline a. Source: IDWR & - WIB Number & 44. & & & & & \\
\hline
\end{tabular}


TABLE 6. BASIC DATA TABLE OF CHEMICAL ANALYSES OF WATER FROM SELECTED WELLS AND SPRINGS IN THE WEISER RIVER BASIN

\begin{tabular}{|c|c|c|c|c|c|c|}
\hline & 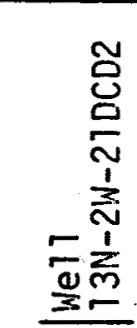 & 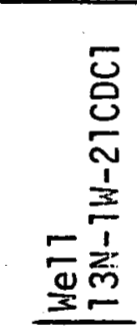 & 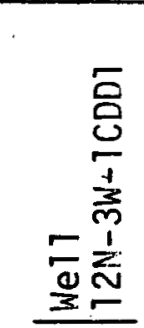 & 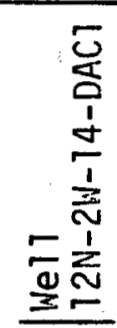 & 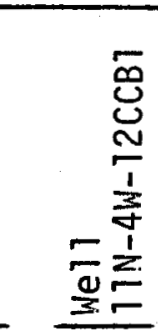 & 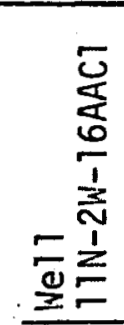 \\
\hline $\begin{array}{c}\text { Discharge } \\
(1 / \mathrm{s})\end{array}$ & 0.6 & 0.8 & 0.8 & 1.0 & - & 140 \\
\hline $\mathrm{Ca}$ & 66 & 13 & 30 & 12 & 20 & 31. \\
\hline$k$ & 4.5 & 6.7 & 9 & 5.4 & 8.4 & 13 \\
\hline $\mathrm{Mg}$ & 26 & 6 & 18 & 4 & 8.2 & 19 \\
\hline $\mathrm{Na}$ & 23 & 12 & 16 & 12 & 13 & 26 \\
\hline $\begin{array}{l}\mathrm{SiO}_{2} \\
\mathrm{Cl}^{-}\end{array}$ & 75 & 57 & 41 & 66 & 48 & 81 \\
\hline $\mathrm{F}^{-}$ & & & & & & \\
\hline $\mathrm{HCO}_{3}^{-}$ & 59 & 122 & 232 & 98 & 119 & 283 \\
\hline $\mathrm{SO}_{4}=$ & 230 & 4 & 5.8 & 8.2 & 8.4 & 11 \\
\hline $\begin{array}{l}\text { Conductivity } \\
\text { (umhos) }\end{array}$ & 700 & 193 & 333 & 171 & 203 & 440 \\
\hline $\begin{array}{l}\text { Total } \\
\text { Dissolved } \\
\text { Solids }\end{array}$ & 499 & 167 & 236 & 160 & 181 & 323 \\
\hline $\mathrm{pH}$ & 6.3 & 8.0 & 7.0 & 7.3 & 37.0 & 8.0 \\
\hline
\end{tabular}




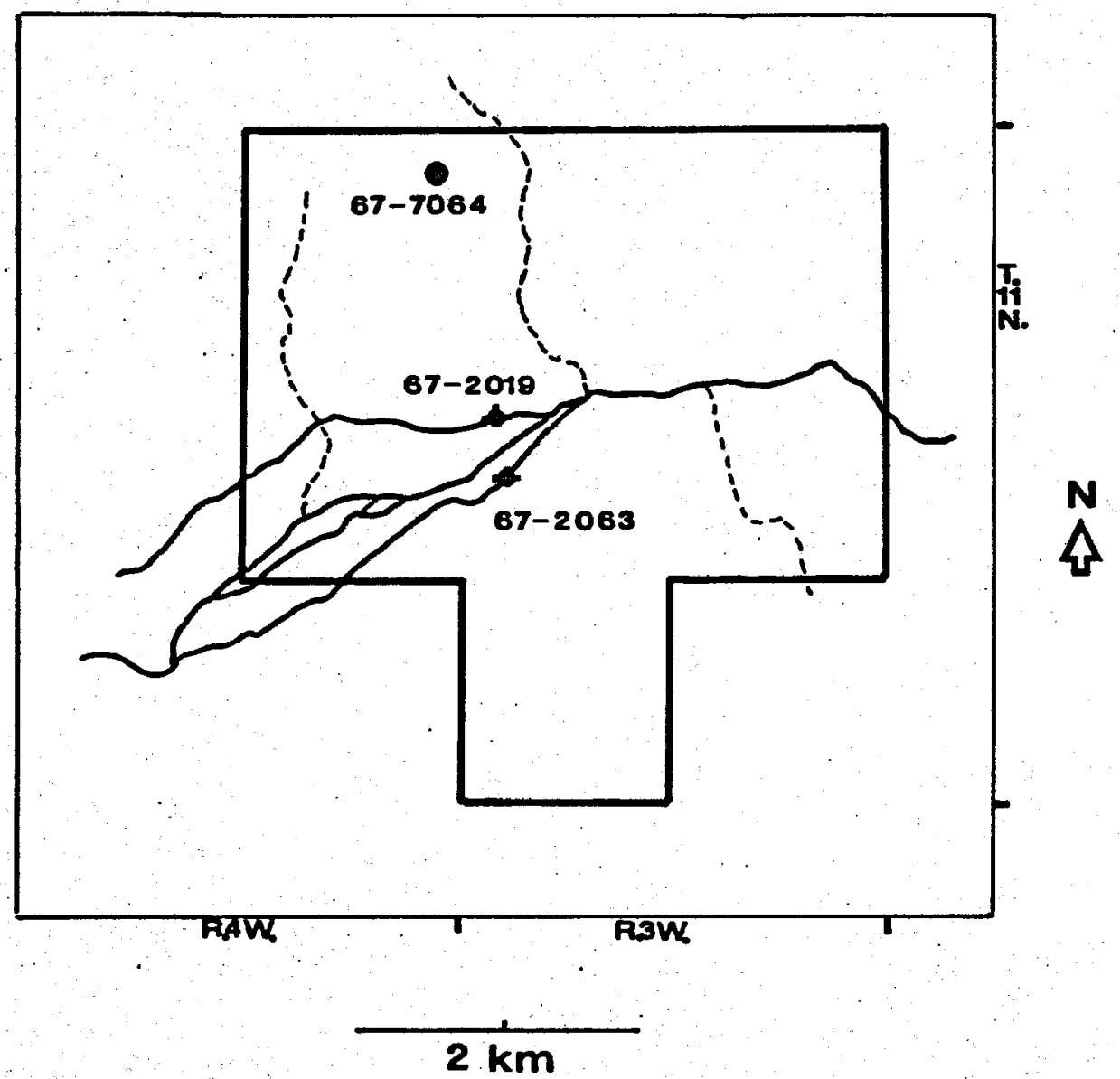

Figure 13. Known water rights in the Crane Creek KGRA. 
TABLE 7. WATER RIGHTS INFORMATION FOR THE CRANE CREEK KGRA AREA

$\begin{array}{llll}\text { File Number } & & \text { Quantity (cfs) } & \text { Priority Date } \\ 67-2019 & & 0.2 & 03 / 14 / 07 \\ 67-2063 & 1.4 & 10 / 11 / 11 \\ 67-7064 & 0.03 & \end{array}$

a. Source: Files of IDWR. 


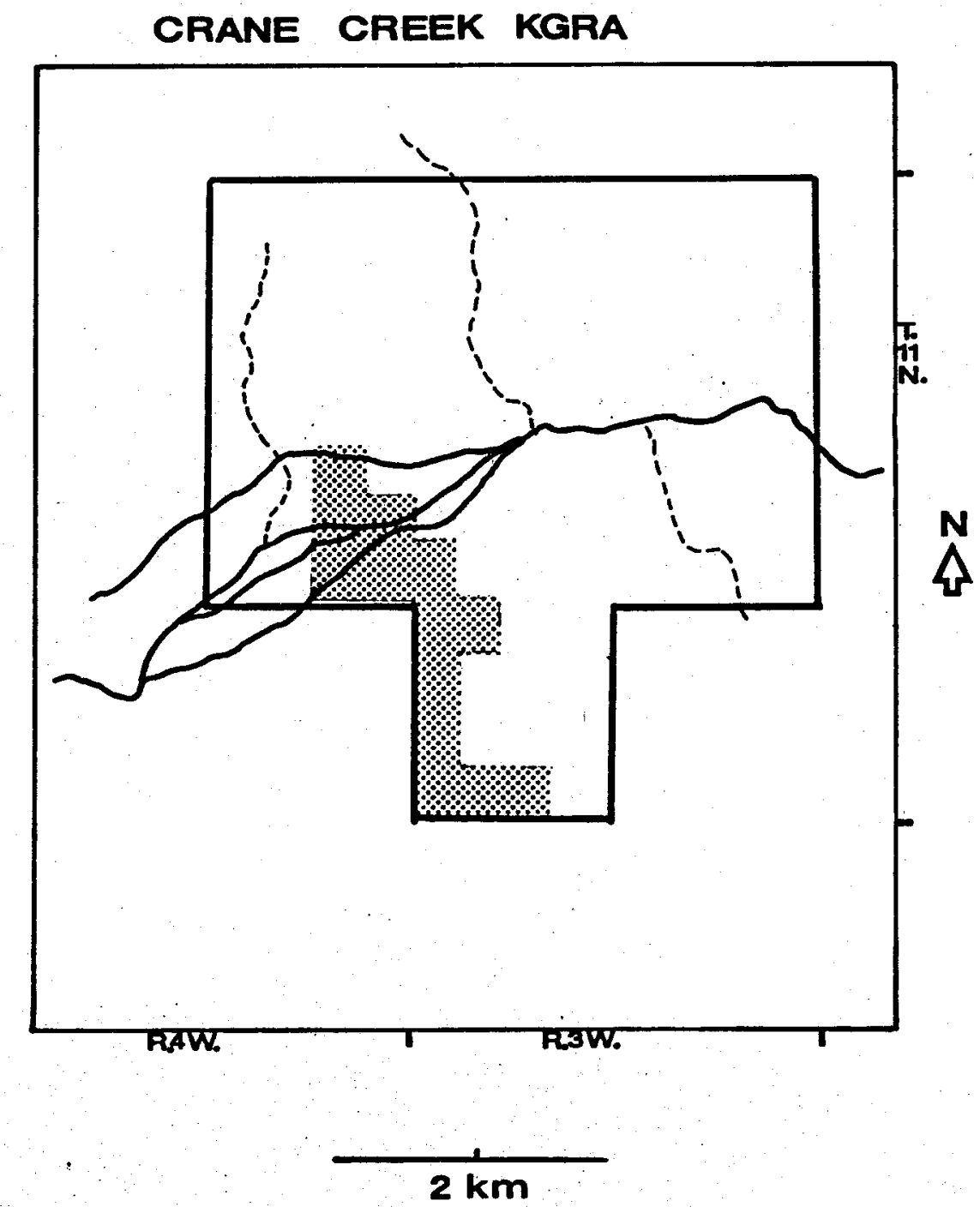

Figure 14. Location of Soil Conservation Service soil survey (Washington County). 
1. Soil taxonomic class

2. Typical soil profile:

Depth

Color

Texture

Composition

$\mathrm{pH}$

3. Range in characteristics:

Mean annual soil temperature

Mean summer soil temperature

Relative moisture content

Depth to bedrock

Organic content

Structure

4. Geographic setting:

Elevation

Slope

Parent materials

Climate

5. Drainage:

Permeability (in./hr)

Available water capacity (in./in.)

So il reaction ( $\mathrm{pH})$

Salinity

6. Use and vegetation potentials:

Sanitary facilities

Commun ity development

Source materials

Water management

Wildlife habitat

Native vegetation

Crop use and potential 
In 1976, the Boise District, Bureau of Land Management completed an environmental assessment of the Crane Creek KGRA. Figure 15 shows a reconnaissance soil association map of the KGRA and adjacent lands from this assessment. The map legend describes the soil types and general land uses within the area. Soil data include general information on composition, depth, parent materials, landtypes, and slope gradient.

Approximately $75 \%$ of the Crane Creek KGRA is underlain by shallow, stony soils on steep slopes indicating both topographic and drainage limitations to geothermal development. Developed farmlands comprise most of the flat bottomlands and dissected terrace lands representing possible land use conflicts with geothermal development.

The Washington County SCS will complete a detailed soil survey of the county by 1983. The remaining private lands with in the crane Creek KGRA may be mapped during the summer of 1979. Soils on specific sites chosen for geothermal development should be mapped at the level of detail prescribed by the SCS.

\section{Biological Environment}

The biological environment of Crane Creek KGRA is discussed in detail in the following sections: Terrestrial and Aquatic Ecology.

Terrestrial Ecology (T. L. Johnson and C. D. Jorgensen, BYU)

The assessment of the terrestrial ecology for the Crane Creek KGRA examined the habitats associated with the region. The potential impact of possible geothermal development was assessed with regard to habitats found in the KGRA and their relative abundance within the region. 


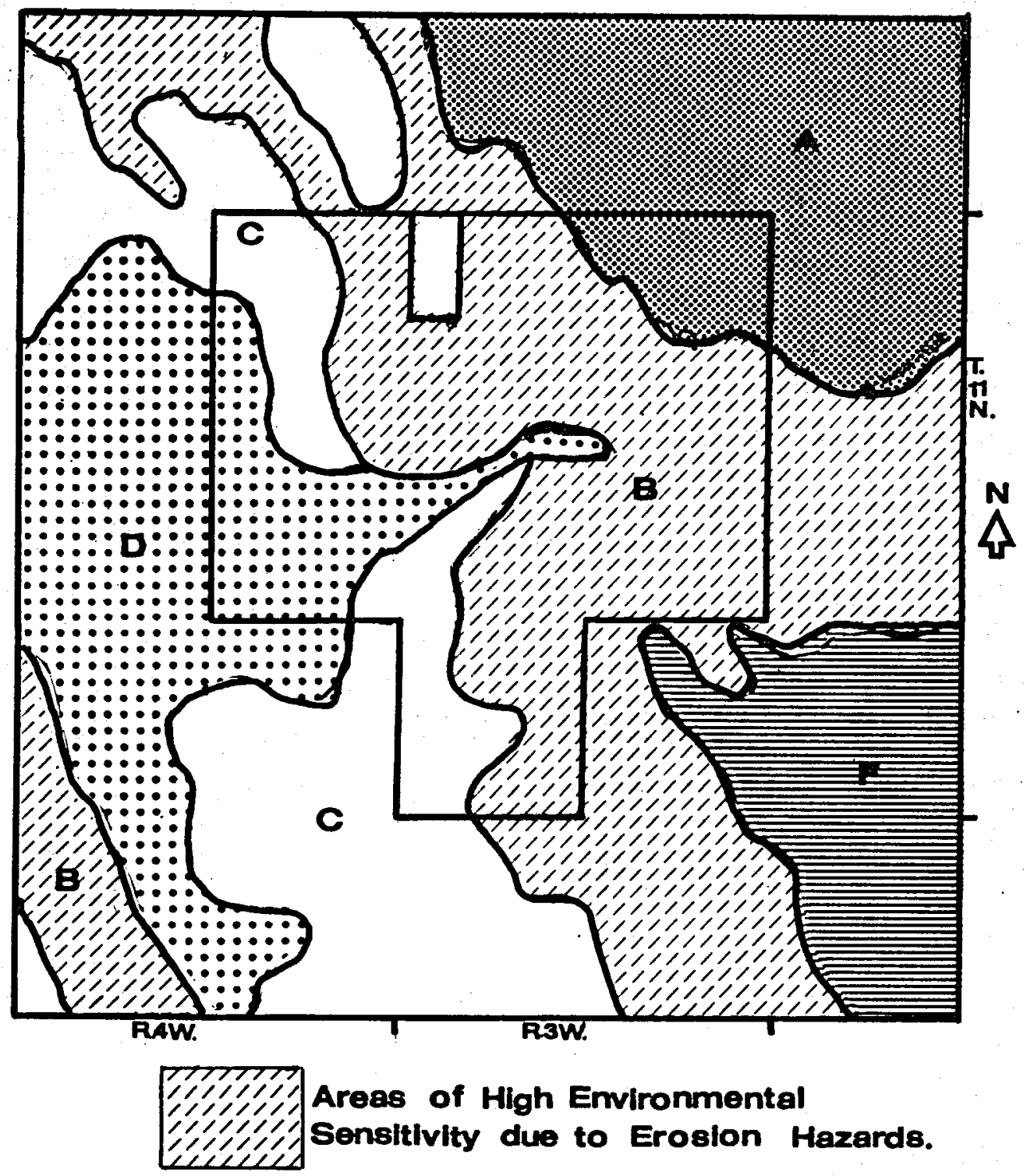

\section{$2 \mathrm{~km}$}

Figure 15. Areas in Crane Creek KGRA of high environment sensitivity due to erosion hazards (BLM soil survey, 1976) (legend follows). 


\section{Legend for Figure 15}

Soils

There are six so il associations found in the area. They consist of the following types:

A. Very shallow $(0$ to $25 \mathrm{~cm})$ and shallow $(25$ to $50 \mathrm{~cm})$ very stony loams to $\mathrm{clays}$ overlying basalt bedrock. Slopes range generally from 0 to $30 \%$.

B. Very shallow and shallow, very stony loams and clay loams overlying basalt with numerous outcroppings of bedrock. Slopes are generally more than $30 \%$.

C. Shallow to deep loams to clays (may or may not be stony) developed on dissected terraces and hills overlying basalt bedrock. Slopes generally range from 10 to $30 \%$.

D. These are moderately deep to deep well drained to poorly drained, nearly level to moderately sloping soils on stream bottoms and terraces. Slopes generaliy less than $15 \%$.

E. These are moderately deep loamy soils developing on dissected terraces and hills overlying basalt bedrock. Slopes range from 10 to $30 \%$.

F. These are generally deep, loam and silt loam soils that are developed on dissected terraces and hills overlying basalt bedrock. Slopes range from about 15 to $50 \%$.

Areas of high soil erosion hazard are shown in Figure 15. Shaded portions of the map indicate areas of high environmental sensitivity due to soil composition and erosion factors. 
Flora. The Crane Creek KGRA is located in the Tall Sagebrush vegetative habitat (Figure 16), but differs somewhat from Tall Sagebrush in the other Snake River Plain KGRAs. The variation provides more diversity in habitats as well as making riparian or wash-type cormunities more important.

Threatened and endangered $\mathrm{plant}$ species are illustrated with respect to their proximity to the KGRA in Figure 17 . Records of these plant species were usually from museum collections only, not from extensive studies. Data for the proposed threatened and endangered plant species were taken directly from Henderson et al. ${ }^{18}$ Their study not only recormends a status based on the existing state of knowledge, but makes some recormendations of change in status. Only those whose status appears critical because of a lack of information or extremely limited distributions are discussed beyond merely illustrating their status. Specific efforts have not been made to establish their status; the data are almost incidental and need much more validation to be conclusive.

Fauna. Species of vertebrates were compiled for Crane Creek, based largely on their reported association with habitats included in the area. These data were collected from numerous sources. Since none of the data were specifically concerned with geothermal development, they represent the best estimate of what might be expected. Specific onsite research would be required to validate species present and relative numbers; but in the absence of such data, these listings represent the best summary of what is included in the resources available. The listings (Tables 8 through 11) are as comprehensive as possible, with reported species being deleted only if there is reason for doing so.

Most of the information included in Tables 8 through 11 was available from a limited number of resources. 


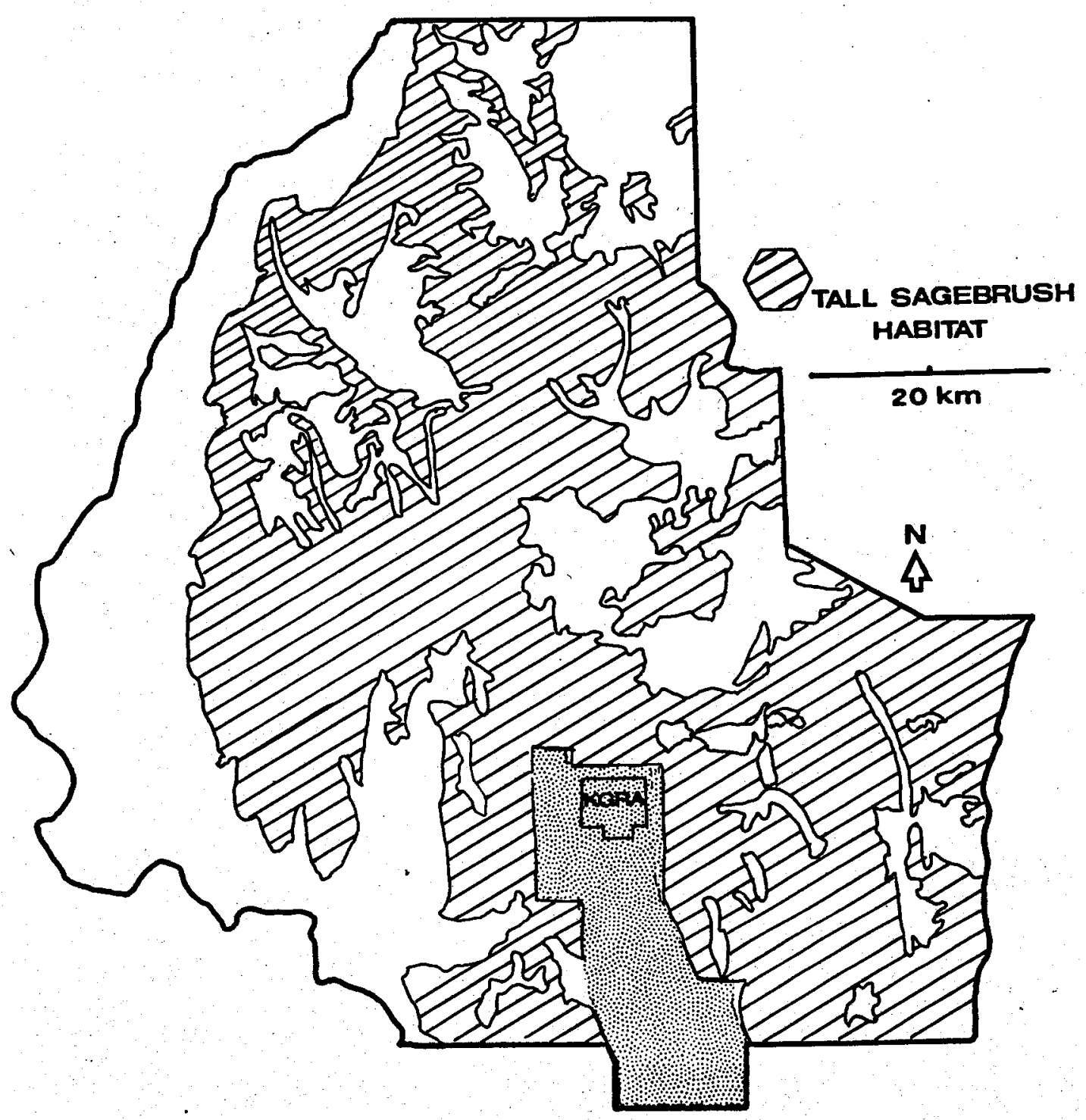

Figure 16. Relative extent of the Tall Sagebrush vegetation habitat (shaded area) within the Crane Creek KGRA and its associated non-competitive lease application area (Stippled area). 


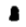

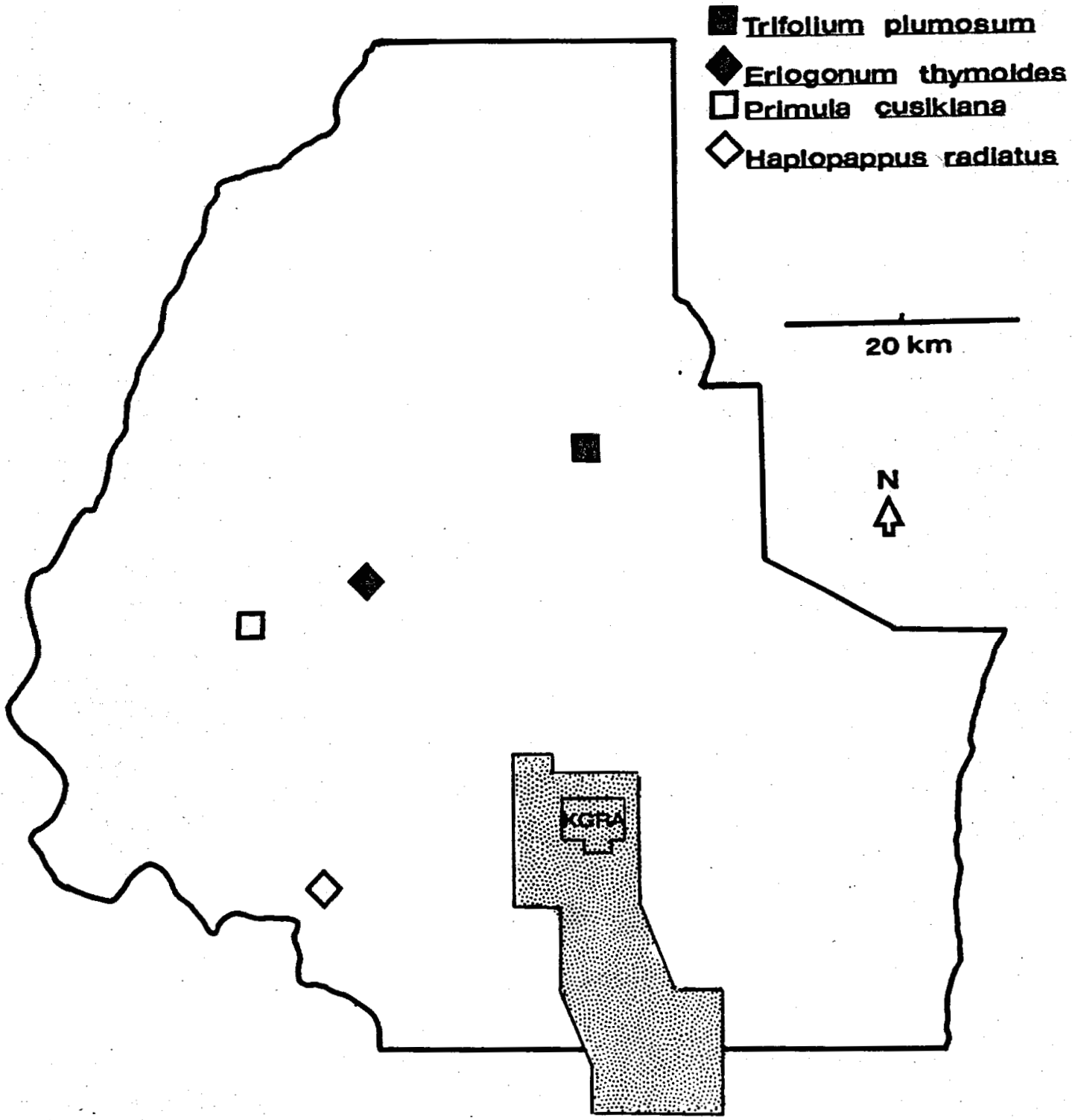

Figure 17. Recorded distributions of threatened and endangered plant species in Washington County. Note: This figure is followed by six pages of specific information concerning these species. Species included are: Eriogonum thymoides, Primula cusickiana, Haplopappus radiatus, Trifolium plumosum amplifolium. 


\section{ASTERACEALE (Compositae)}

\section{Haplopappus radiatus}

Location:

Land Ownership:

Idaho: Washington County; Oregon: Baker, Malheur and Wallowa counties "South end of Snake River Canyon in Oregon and Idaho".

Judging from locations and general description mostly private but some BLM is likely and U.S.F.S. (Payette N.F.) possible.

Vegetation Type: Grasslands or sagebrush/grass comunities.

Habitat: $\quad$ Undetermined, much may have been inundated by Snake River reservoirs.

Hazards: Unknown.

Herbarium Data: Number of sites by county: Idaho --

Washington - 1; Oregon--Baker - 1, Malheur - 1, Wallowa - 1 (reported).

Number of collections $n$ herbaria searched:

BOIS - 0, BS - 0, CIC - 1, ID - 1, IDF - 0, IDS - 0, WS - 1 .

Remarks:

The WS and ID material was filed under II. carthamoides var. maximus and $\mathrm{H}$. radiatis; thus herbaria could be missing this taxon when asked to search for H. radiatus. Certainly very uncommon in Idaho, although the type collection was probably made right across the state line (Snake River) in Oregon. 
Recommendation: Retain as endangered.

References: Lee (1968) does not recognize this taxon.

Compiler: Johnson.

FABACEAE (Legaminosae)

Trifolium plumosum Dougl.

Var. amplifolium

Location: Idaho: Idaho, Nez Perce, Lewis, Clearwater, and Washington counties; Idaho endemic variety.

Land Ownership: Uncertain, private, primarily, one collection from U.S.F.S. (Clearwater N.F.), and several periphera to U.S.F.S. (Nez Perce and Payette N.F.) possibly Idaho Department of Lands.

Vegetation Type: In middle elevation grasslands (600 to $1200 \mathrm{~m}$ ) and in open Pinus ponderosa forests.

Habitat:

"low places in meadow areas," "dry grassy flat," "dry, open slopes," "open forest with pinus ponderosa and Symphoricarpos" "Festuca/Agropyron ... zone".

Hazards: Undetermined, but most of the sites are in areas with a long history of grazing.

Herbarium Data: Number of sites by county: Idaho -Clearwater - 1, Idaho - 3, Lewis - 2, Nez Perce - 4, Washington - 1 . 
Number of collections in herbaria searched: BOIS - 0, BS - 0, CIC - 0, ID - 4, IDF - 0, IDS - 0, RENO - 5, UTC - 2, WS - 7. (From the above, seven separate collections are from a single area along U.S. 95 in Idaho County).

Remarks:

Much more widespread than indicated in Hitchcock et al (1961) or Hitchcock \& Cronquist (1973).

Recommendation: While not common, the extent of the population seems to indicate that removal from threatened status would be possible with either a more extensive herbarium search and/or a small amount of field work, particularly to note the impact of grazing. For now. Retain as threatened.

Compiler: : Johnson.

\section{POLYGONACEAE}

\section{Eriogonum thymoides}

Location:

Idaho: Blaine, Camas, possibly Elmore, Gooding, Lincoln, and Washington counties;

Oregon: Union County;

Washington: Chelan, King, and Kittitas counties.

Land Ownership: BLM, private and possible Idaho Department of Lands.

Vegetation Type: Sagebrush/grass.

Habitat: $\quad$ Thin rocky soil. 
Hazards:

Collected by "bonsai gardeners", range improvement programs.

Herbarium Data: $\quad$ Number of sites by county: Idaho -- Blaine - 2, Camas - 1, Washington - 2. Number of collections in herbaria searched: BOIS - 0, CIC - 2, ID - 3, IDF - 4, IDS - 2, WS - 0 .

Remarks:

This plant is common in the Bennett Hills area and has a wide distribution from there to Chelan County, Washington. It is rare in the Washington County area and may be locally jeopardized, especially near highways where it is apparently collected for "bonsai" arrangements.

Recommendation: Remove from threatened list.

Compiler: $\quad$ Packard.

\section{PRIMULACEAE}

\section{Primula cusickiana}

Location:

Idaho: Ada, Adams, Blaine, Boise, Camas, Custer, Elmore, Gem, Gooding, Idaho, Owyhee, Valley, and Washington counties;

Oregon: Wallowa county.

Land Ownership: BLM U.S.F.S. (Boise, Payette, and Sawtooth N.F.), probably private and Idaho Department of Lands.

Vegetation Type: Mostly in grass meadows or sagebrush/grass. 
Habatit:

Hazards:

Herbarium Data:

Remarks:
The more northern population grows in mountain meadows in heavy clay soil. The southern populations grow in thin, rocky soil on steep slopes of eroded lake terraces and in seeps or where it is wet in spring.

Many populations are subject to grazing; many more have been destroyed by agriculture and housing developments. This plant is attractive and tempting to transfer to the garden but transplants very poorly.

Number of sites by county: Idaho -- Ada - 9, many since destroyed, Adams - 2, Blaine - 1, Boise - 5, Camas - 4, Custer - 3, Elmore - 7, Gem - 1, Gooding - 2, Idaho - 2, Owyhee - 1, Washington - 2 .

Number of collections in herbaria searched: BOIS - 3, BS - 5, CIC - 18, ID - 15, IDF - 2, INT - 9, WS - 3, WTU - 2 .

Dr. Marion Ownbey once said (pers. comm.) that probably three species of Primula are represented. The Hill City population being one undescribed species, the Boise area population being the now unrecognized $P$. wilcoxiana, and the more northern population being the typic P. cusickiana. The difference in habitat preference indicates that this might be true. If, as "Ownbey indicated, this is actually three species, then the Hill City population is truly endangered and the Boise $P$. wilcoxiana is possibly threatened. The $P$. cusickiana of the Wallowa Mountains and west-central Idaho is neither endangered nor threatened. 
Recommendation: Retain on endangered list until the taxonomy of these populations has been $c l$ arified. Then remove or reduce in status any segment of the complex that does not warrant protection.

References: $\quad$ Eidemiller 1976

Holmgren and Holmgren 1974

Williams 1936.

Compiler: Packard. 
TABLE 8. RELATIVE ABUNDANCE AND HABITAT LISTINGS FOR AMPHIBIANS IN THE CRANE CREEK KGRA

\begin{tabular}{|c|c|c|c|c|c|c|c|c|}
\hline \multicolumn{2}{|c|}{ Spectes } & \multicolumn{4}{|c|}{ Relative Abundance ${ }^{a}$} & \multicolumn{3}{|c|}{ Habitat Types } \\
\hline Common Nane & Scientif ic Name & $\mathrm{Sp}$ & Su & $\mathrm{Fa}$ & W1. & 1 & 2 & 3 \\
\hline Tiger Sal anander & Ambystoma tigrinum & I. & $\mathbf{L}$ & L. & $\mathbf{L}$ & & & $\mathrm{x}$ \\
\hline Long-toed Salamander & Ambystoina macrodactylum & $\mathbf{L}$ & I. & $\mathbf{L}$ & I. & & & $x$ \\
\hline Great Basin Spadefoot & Scaphiopus interinontanus & $\mathbf{L}$ & $\mathbf{L}$ & $\mathbf{L}$ & $\mathbf{L}$ & & & $\mathbf{x}$ \\
\hline Western Toad & Bufo boreas & $M$ & $\mathbf{M}$ & $M$ & $\mathbf{M}$ & & $\mathbf{x}$ & $x$ \\
\hline Woodhouse's road & Bufo woodhouse & $\mathbf{P}$ & - & - & - & & & $\mathrm{x}$ \\
\hline Chorus Frog & Pseudacris triseriata & $\mathbf{L}$ & $\mathbf{L}$ & I. & $\mathbf{I}$ & & & $\mathrm{x}$ \\
\hline Pacific Treefrog & llyla regilla & L & $\mathbf{L}$ & L. & L. & & & $\mathrm{x}$ \\
\hline Spotted Frog & Rana pretiosa & $\mathbf{L}$ & $\mathbf{L}$ & I. & L & & & $\mathbf{x}$ \\
\hline Bullfrog & Rana catesbelana & $M$ & $M$ & $M$ & $M$ & & & $\mathbf{X}$ \\
\hline
\end{tabular}

- Key to Relative Abundance: li=High, M=Medium, L=Low, A=Absent, P=Population level unknown, U=Presence unknown.

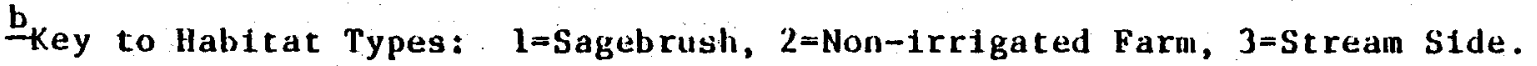


TABLE 9. RELATIVE ABUNDANCE AND HABITAT LISTINGS FOR REPTILES IN THE CRANE CREEK KGRA

\begin{tabular}{|c|c|c|c|c|c|c|c|c|}
\hline \multicolumn{2}{|c|}{ Species } & \multicolumn{4}{|c|}{ Relative Abundance $\mathrm{a}^{\mathrm{a}}$} & \multicolumn{3}{|c|}{ Hab it at Types } \\
\hline Common Name & Scientific Name & Sp & su & $\mathbf{F a}$ & Wi & 1 & 2 & 3 \\
\hline Western Fence Lizard & Sceloporus occidentalis & $\mathbf{L}$ & $\mathbf{L}$ & $\mathbf{L}$ & $\mathbf{L}$ & $x$ & $\mathrm{x}$ & \\
\hline Sagebrush Lizard & Sceloporus graclosus & I & $\mathbf{L}$ & $\mathbf{L}$ & $\mathbf{L}$ & $\mathrm{X}$ & $\mathrm{X}$ & \\
\hline Western Skink & Eumeces skiltonianus & L & $\mathbf{L}$ & $\mathbf{L}$ & L & & $\mathrm{x}$ & \\
\hline Racer & Coluber constrictor & L & $\mathbf{L}$ & I. & L & & $\mathrm{X}$ & $\mathbf{x}$ \\
\hline Gopher Snake & P1tuophis melanoleucus & $\mathbf{L}$ & $\mathrm{L}$ & $\mathbf{L}$ & $\mathbf{L}$ & & $x$ & $x$ \\
\hline Comunon Garter Snake & Thamnophis sirtalis & $\mathbf{L}$ & I. & $\mathbf{L}$ & $\mathbf{L}$ & $\mathbf{x}$ & $\mathrm{x}$ & $\mathbf{x}$ \\
\hline Western Garter Snake & Thamnophis elegans & $\mathbf{L}$ & I. & $\mathbf{L}$ & I. & & $x$ & $\mathbf{x}$ \\
\hline Western Ground Snake & Sonora semtannulata & $\mathbf{L}$ & $\mathbf{L}$ & L. & $\mathbf{P}$ & $\mathbf{X}$ & & \\
\hline Western Rattlesnake & Crotalus viridis & M & M & M & M & $\mathrm{x}$ & $\mathrm{x}$ & $\mathbf{x}$ \\
\hline
\end{tabular}

- Key to Relative Abundance: $H=H 1 \mathrm{gh}, \mathrm{M=Medium,} \mathrm{L=Low,} A=A b s e n t, P=$ Population level unknown, $J=P r e s e n c e$ unknown.

bey to Habitat Types: 1=Sagebrush, 2=Non-irrigated Farm, 3=Strean Side. 
TABLE 10. RELATIVE ABUNDANCE AND HABITAT LISTINGS FOR BIRDS IN THE CRANE CREEK KGRA

\begin{tabular}{|c|c|c|c|c|c|c|c|c|}
\hline \multicolumn{2}{|c|}{ Species } & \multicolumn{4}{|c|}{ Relative Abundance } & \multicolumn{3}{|c|}{ Habitat Types } \\
\hline Comunon Naine & Sclentif ic Name & $\mathbf{S p}$ & Su & $\mathbf{F a}$ & Wi & 1 & 2 & 3 \\
\hline Western Grebe & Aechmophorus occldental is & HI & $\mathbf{M}$ & H & $\mathbf{L}$ & & & $\mathrm{X}$ \\
\hline Horned Grebe & Podlceps auritus & $\mathbf{U}$ & $\mathbf{U}$ & $\mathbf{U}$ & $\mathbf{U}$ & & & \\
\hline Eared Grebe & Podiceps caspicus & $M$ & $M$ & M & $\mathbf{p}$ & & & $\mathrm{x}$ \\
\hline Pted-billed Grebe & Podilymbus podiceps & $M$ & M & M & $\mathbf{P}$ & . & & $\mathrm{x}$ \\
\hline Whistling Swan & olor columbianus & $\mathbf{L}$ & $\mathbf{P}$ & $\mathbf{L}$ & $\mathbf{P}$ & & & $\mathrm{x}$ \\
\hline Canada Goose & Branta canadensis & H & H & H & H & & $\mathrm{x}$ & $\mathrm{x}$ \\
\hline Snow Coose & Chen hyperborea & $\mathbf{u}$ & $\mathbf{u}$ & $\mathbf{U}$ & $\mathbf{U}$ & & & \\
\hline Mallard & Anas platyrhynchos & $\mathbf{H}$ & H. & H & $\mathbf{M}$ & $\mathbf{x}$ & $\mathrm{x}$ & $\mathrm{x}$ \\
\hline Pintall & Anas acuta & $\mathbf{H}$ & $\mathbf{M}$ & H & $\mathbf{L}$ & & & $\mathrm{x}$ \\
\hline Gadwall & Anas strepera & M & $\mathbf{L}$ & M & $\mathbf{P}$ & & & $\mathrm{x}$ \\
\hline Wigeon & Anas americana & li & $\mathbf{H}$ & H & $\mathbf{L}$ & & & $\mathrm{x}$ \\
\hline Northern Shoveler & Anas clypeata & $\mathbf{L}$ & $\mathbf{L}$ & L & $\mathbf{P}$ & & & $\mathrm{x}$ \\
\hline Blue-w Inged Teal & Anas discors & $M$ & $\mathbf{M}$ & $M$ & $\mathbf{L}$ & & & $\mathrm{x}$ \\
\hline Cinnamon Teal & Anas cyanoptera & $\mathbf{M}$ & M & $\mathbf{M}$ & $\mathbf{P}$ & & & $\mathrm{x}$ \\
\hline Green-w1nged Teal & Anas crecca & H & H & H & I. & & $x$ & $\mathrm{x}$ \\
\hline Wood Duck & Aix sponsa & H & $\mathbf{H}$ & 11 & $\mathbf{L}$ & & & $\mathrm{x}$ \\
\hline Redhead & Aythya americana & $\mathbf{L}$ & L. & L & $\mathbf{P}$ & & & $\mathrm{x}$ \\
\hline Canvasback & Aythya valisiner & $\mathbf{P}$ & $\mathbf{P}$ & $\mathbf{P}$ & $\mathbf{p}$ & & & \\
\hline Ring-necked Duck & Aythya collaris & $\mathbf{P}$ & $\mathbf{p}$ & $\mathbf{P}$ & $\mathbf{P}$ & & & \\
\hline Greater Scaup & Aythya marila & M & $\mathbf{P}$ & M & $\mathbf{L}$ & & & $\mathrm{x}$ \\
\hline Lesser Scaup & Aythya affinds & M & $\mathbf{P}$ & H & $\mathbf{p}$ & & & $\mathrm{x}$ \\
\hline Common Goldeneye & Bucephala clangula & H & II & $\mathbf{H}$ & M & & & $\mathrm{x}$ \\
\hline Barrow's Goldeneye & Bucephala islandica & $\mathbf{M}$ & $\mathbf{L}$ & $M$ & $\mathbf{L}$ & & & $\mathrm{X}$ \\
\hline Buff lehead & Bucephala albeola & $\mathbf{H}$ & $\mathbf{L}$ & H & $\mathbf{L}$ & & & $\mathrm{x}$ \\
\hline Ruddy Duck & Oxyura jamaicensis & $\mathbf{H}$ & M. & H & L & & & $\mathrm{x}$ \\
\hline
\end{tabular}


TABLE 10. (continued)

\begin{tabular}{|c|c|c|c|c|c|c|c|c|c|}
\hline \multirow{2}{*}{ Common Name } & \multicolumn{2}{|c|}{ Species } & \multicolumn{4}{|c|}{ Relative Abundance ${ }^{\mathrm{a}}$} & \multicolumn{3}{|c|}{ Habitat Types $\underline{b}$} \\
\hline & . & Scientific Name & $\mathrm{Sp}$ & Su & $\mathrm{Fa}$ & Wi & 1 & 2 & 3 \\
\hline Conmon Merganser & & Mergus merganser & H & $\mathbf{H}$ & H & H & & & $x$ \\
\hline Red-breasted Merganser & & Mergus serrator. & $M$ & $\mathbf{M}$ & $\mathbf{M}$ & $M$ & & & $\mathrm{x}$ \\
\hline llooded Merganser & & Lophodytes cuculiatus & $\mathbf{L}$ & $\mathbf{L}$ & $\mathbf{L}$ & $\mathbf{P}$ & & & $\mathbf{x}$ \\
\hline Turkey vulture & & Cathartes aura & $\mathbf{L}$ & $\mathbf{L}$ & $\mathbf{L}$ & $\mathbf{P}$ & $\mathbf{x}$ & $\mathrm{x}$ & \\
\hline Goshawk & & Acciptter gentilis & $\mathbf{P}$ & $\mathbf{P}$ & $\mathbf{P}$ & $L$ & $\mathbf{x}$ & & \\
\hline Cooper's Hawk & $\cdot$ & Accipiter cooperil & $\mathbf{L}$ & I. & $\mathbf{L}$ & $\mathbf{L}$ & $\mathbf{x}$ & $\mathbf{x}$ & \\
\hline Sharp-shinned Hawk & & Accipiter striatus & I. & I. & $\mathbf{L}$ & $\mathbf{L}$ & $\mathrm{x}$ & $\mathrm{x}$ & \\
\hline Marsh llawk & & Circus cyaneus & $\mathrm{H}$ & H & $\mathbf{M}$ & L. & $\mathrm{x}$ & $\mathbf{x}$ & $x$ \\
\hline Rough-legged Hawk & & Buteo lagopus & $\mathbf{M}$ & $\mathbf{M}$ & $M$ & $\mathbf{H}$ & $\mathbf{x}$ & $\mathbf{x}$ & $\mathbf{x}$ \\
\hline Red-tailed Hawk & & Buteo jamaicensis & M & $\mathbf{M}$ & $M$ & II & $x$ & $\mathrm{x}$ & $\mathrm{x}$ \\
\hline Ferruginous Hawk & & Buteo regalis & L & $\mathbf{L}$ & L & $\mathbf{L}$ & & & $\mathrm{x}$ \\
\hline Swainson's Hawk & & Buteo swainsoni & $M$ & $\mathbf{M}$ & $M$ & $\mathbf{M}$ & $x$ & $\mathbf{x}$ & $\mathbf{x}$ \\
\hline Golden Eagle & & Aquila chrysaetos & H & $\mathbf{H}$ & H & H & $\mathbf{x}$ & $\mathrm{X}$ & $\mathbf{x}$ \\
\hline Bald Eagle & & la11aeetus leucocephalus & M & $\mathbf{L}$ & $\mathbf{L}$ & $\mathbf{H}$ & $\mathrm{x}$ & $\mathrm{X}$ & $\mathrm{x}$ \\
\hline Osprey & & Pandion hal taetus & $\mathbf{L}$ & L. & $L$ & $\mathbf{P}$ & & & $\mathrm{x}$ \\
\hline Prairie Falcon & & Falco mextcanus & M & $\mathbf{M}$ & $\mathbf{M}$ & $M$ & $\mathbf{X}$ & $\mathrm{X}$ & \\
\hline Merlin & & Falco columbarius & $\mathbf{u}$ & $\mathbf{U}$ & $\mathbf{U}$ & $\mathbf{U}$ & & & \\
\hline American Kestrel & & Falco sparverius & $\mathbf{H}$ & HI & 11 & $M$ & $\mathrm{x}$ & $\mathbf{X}$ & $\mathrm{x}$ \\
\hline B lue Grouse & & Dendragapus obscurus & $\mathbf{H}$ & II & HI & 11 & $\mathrm{x}$ & $\mathrm{X}$ & $x$ \\
\hline Ruffed Grouse & & Bonasa umbel]us & M & M & M & M & $\mathrm{x}$ & & $\mathrm{x}$ \\
\hline Sharped-talled Grouse & & Pedioecetes phasianellus & $\mathbf{L}$ & $\mathbf{L}$ & I. & $\mathbf{L}$ & $\mathbf{x}$ & $\mathbf{x}$ & \\
\hline Sage Grouse & & Centrocercus urophasianus & $\dot{M}$ & $\mathbf{M}$ & $M$ & $\mathbf{M}$ & $\mathbf{x}$ & $\mathbf{X}$ & $x$ \\
\hline California Quall & & Lophortyx californicus & $\mathbf{H}$ & H & $\mathbf{H}$ & HI & $x$ & $\mathrm{x}$ & $x$ \\
\hline Ringed-necked Pheasant & & Phasianus colclicus & $\mathbf{H}$ & $\mathbf{H}$ & HI & H & $\mathbf{x}$ & $\mathrm{x}$ & $\mathrm{x}$ \\
\hline Chukar & & Alectoris chukar & HI & H & $\mathbf{H}$ & HI & $\mathrm{x}$ & $\mathrm{x}$ & $\mathrm{x}$ \\
\hline
\end{tabular}

$\Gamma$ 
TABLE 10. (continued)

\begin{tabular}{|c|c|c|c|c|c|c|c|c|}
\hline \multicolumn{2}{|c|}{ Spectes } & \multicolumn{4}{|c|}{ Relative Abundance } & \multicolumn{3}{|c|}{ Habitat Types } \\
\hline Comnion Name & Scientific Name & $\mathrm{Sp}$ & Su & Fa & W1 & 1 & 2 & 3 \\
\hline Gray Partridge & Perdix perdix & $\mathbf{H}$ & $\mathbf{H}$ & UI & $\mathbf{H}$ & $\mathbf{X}$ & $\mathbf{x}$ & $x$ \\
\hline Great Blue lleron & Ardea herodias & II & $\mathbf{H}$ & H & $\mathbf{L}$ & $\mathbf{X}$ & & $\mathbf{X}$ \\
\hline Common Egret & Casmerodlus albus & $\mathbf{U}$ & $\mathbf{U}$ & $\mathbf{U}$ & $\mathbf{U}$ & & & \\
\hline Snowy Egret & Leucophoyx thula & $\mathbf{L}$ & $\mathbf{L}$ & L & $\mathbf{p}$ & & & $\mathbf{x}$ \\
\hline Black-crowned Night Heron & Nyct icorax nycticorax & $\mathbf{L}$ & $\mathbf{L}$ & L. & $\mathbf{P}$ & & & $\mathbf{X}$ \\
\hline American Bittern & Botaurus lentiginosus & $\mathbf{M}$ & $\mathbf{M}$ & $\mathbf{M}$ & $\mathbf{P}$ & & & $\mathbf{x}$ \\
\hline White-faced Ibis & Plegadis chilit & $\mathbf{p}$ & $\mathbf{p}$ & $\mathbf{P}$ & $\mathbf{p}$ & & & \\
\hline Virginia Rail & Ra1lus Iimicola & $\mathbf{P}$ & $\mathbf{p}$ & 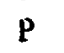 & $\mathbf{P}$ & & & \\
\hline Sora & Poriana carolina & $\mathbf{U}$ & $\mathbf{U}$ & $\mathbf{U}$ & $\mathbf{U}$ & & & \\
\hline American Coot & Fulica americana & $\mathbf{P}$ & $\mathbf{P}$ & $\mathbf{p}$ & $\mathbf{p}$ & & & \\
\hline American Avocet & Recurvirostra anericana & H & H & H & $\mathbf{p}$ & & & $\mathrm{x}$ \\
\hline Semipalmated Plover & Charadrius semipalmatus & $\mathbf{U}$ & $\mathbf{U}$ & $\mathbf{u}$ & $\mathbf{U}$ & & & \\
\hline Killdeer & Charadrius vociferus & $\mathbf{H}$ & $\mathbf{H}$ & H & $\mathbf{L}$ & & $\mathrm{x}$ & $\mathrm{x}$ \\
\hline Common Snipe & Capella gallinago & $\mathbf{p}$ & $\mathbf{P}$ & $\mathbf{P}$ & $\mathbf{P}$ & & & \\
\hline Long-billed Curlew & Numenius americanus & $\mathbf{L}$ & $\mathbf{L}$ & $\mathbf{L}$ & $\mathbf{L}$ & $x$ & $\mathbf{x}$ & \\
\hline Solitary Sandpiper & Tringa solitaria & $\mathbf{p}$ & $\mathbf{P}$ & $\mathbf{P}$ & $\mathbf{P}$ & & & \\
\hline Spotted Sandpiper & Acitis macularia & $\mathbf{p}$ & $\mathbf{P}$ & $\mathbf{p}$ & $\mathbf{p}$ & & & \\
\hline W11let & Catoptrophorus semipa Imatus & II & $\mathbf{H}$ & H & $\mathbf{P}$ & & & $\mathbf{X}$ \\
\hline Greater Yellowlegs & Totanus melanoleucus & $\mathbf{P}$ & $\mathbf{P}$ & $\mathbf{P}$ & $\mathbf{P}$ & & & \\
\hline Lesser Yellowlegs & Totanus flavipes & $\mathbf{p}$ & $\mathbf{p}$ & $\mathbf{P}$ & $\mathbf{P}$ & & & \\
\hline Long-billed Dowitcher & Linnodromus scolopaceus & $\mathbf{U}$ & $\mathbf{U}$ & $\mathbf{U}$ & $\mathbf{U}$ & & & \\
\hline Short-billed Dowitcher & Limnodromus griseus & $\mathbf{M}$ & $\mathbf{M}$ & $\mathbf{M}$ & $\mathbf{p}$ & & & $\mathrm{X}$ \\
\hline Pectoral Sandpiper & Erolia melanotos & $\mathbf{P}$ & $\mathbf{P}$ & $\mathbf{p}$ & $\mathbf{p}$ & & & \\
\hline Sanderling & Crocethia alba & $\mathbf{U}$ & $\mathbf{u}$ & $\mathbf{U}$ & $\mathbf{U}$ & & & \\
\hline Baird's Sandpiper & Erolia bairdii & $\mathbf{U}$ & $\mathbf{U}$ & $\mathbf{U}$ & $\mathbf{U}$ & & & \\
\hline
\end{tabular}


TABLE 10. (continued)

\begin{tabular}{|c|c|c|c|c|c|c|c|c|}
\hline \multicolumn{2}{|c|}{ Species } & \multicolumn{4}{|c|}{ Relative Abundance } & \multicolumn{3}{|c|}{ Habitat Types } \\
\hline Conmon Name & Scientific Nane & $\mathrm{sp}$ & Su & $\mathrm{Fa}$ & Wi & 1 & 2 & 3 \\
\hline Least Sandpiper & Erolia minut11ia & $\mathbf{U}$ & $\mathbf{U}$ & $\mathbf{u}$ & $\mathbf{u}$ & & & \\
\hline Western Sandplper & Ereunetes mauri & $\mathbf{U}$ & $\mathbf{U}$ & $\mathbf{u}$ & $\mathbf{U}$ & & & \\
\hline W1lson's Phalarope & Steganopus tricolor & $\mathbf{P}$ & $\mathbf{P}$ & $\mathbf{P}$ & $\mathbf{P}$ & & & \\
\hline Northern Phalarope & Lobipes lobatus & U & $\mathbf{U}$ & $\mathbf{U}$ & $\mathbf{U}$ & & & \\
\hline Common Snipe & Cape11a gallinago & $\mathbf{P}$ & $\mathbf{P}$ & $\mathbf{P}$ & $\mathbf{P}$ & & & \\
\hline California Gull & Larus californicus & H & H & H & $\mathbf{L}$ & & $\mathbf{x}$ & $\mathbf{x}$ \\
\hline Ring-billed Gull & Larus delawarensis & H & II & H & $\mathbf{L}$ & & $x$ & $\mathrm{x}$ \\
\hline Franklin's Gull & $\overline{\text { Larus pip1 xcan }}$ & $\mathbf{U}$ & $\mathbf{u}$ & $\mathbf{U}$ & $\mathbf{U}$ & & & \\
\hline Forster's Tern & Sterna forster & u & $\mathbf{U}$ & $\mathfrak{u}$ & $\mathbf{u}$ & & & \\
\hline Black Tern & Chlidonias niger & $\mathbf{U}$ & $\mathbf{U}$ & $\mathbf{u}$ & $\mathbf{U}$ & & & \\
\hline Mourning Dove & Zenaldura macroura & H & HI & II & HI & $\mathrm{x}$ & $\mathbf{x}$ & $\mathrm{x}$ \\
\hline Yellow-billed Cuckoo & Coccyzus americanus & $\mathbf{U}$ & $\mathbf{U}$ & $\mathbf{U}$ & $\mathbf{U}$ & & & \\
\hline Black-billed Cuckoo & Coccyzus erythropthalmus & $\mathbf{U}$ & $\mathbf{U}$ & $\mathbf{U}$ & U & & & \\
\hline Great Ilorned Owl & Bubo virgintanus & M & $\mathbf{M}$ & $\mathbf{M}$ & $\mathbf{M}$ & $\mathrm{x}$ & $\mathrm{x}$ & $\mathbf{x}$ \\
\hline Snowy Owl & Nyctea scandlaca & $\mathbf{P}$ & $\mathbf{P}$ & $\mathbf{P}$ & $\mathbf{L}$ & & $x$ & \\
\hline Short-eared Owl & Aslo flanmeus & $\mathbf{l}$ & $\mathbf{L}$ & I. & $\mathbf{p}$ & $\mathbf{x}$ & & \\
\hline Long-eared Owl & Asio otus & $\mathbf{L}$ & $\mathbf{L}$ & $\mathbf{L}$ & $\dot{\mathbf{p}}$ & $\mathrm{x}$ & & \\
\hline Burrowing Ow1 & Speotyto cunicularia & $\mathbf{L}$ & L. & $\mathbf{I}$ & L. & $\mathbf{x}$ & $\mathrm{x}$ & $\mathrm{x}$ \\
\hline Saw-whet Owl & Aegelius acadicus & $\mathbf{U}$ & $\mathbf{u}$ & $\mathbf{U}$ & $\mathbf{U}$ & & & \\
\hline Poor Will & Phalaenoptilus nuttallit & $\mathbf{L}$ & $\mathbf{L}$ & $\mathbf{L}$ & $\mathbf{P}$ & & $\mathrm{x}$ & \\
\hline Common Nighthawk & Chordelles minor & H & II & M & $\mathbf{P}$ & $x$ & $\mathrm{x}$ & $\mathrm{x}$ \\
\hline Black-chinned llummingbird & Archllochus alexandri & $\mathbf{U}$ & $\mathbf{U}$ & $\mathbf{U}$ & $\mathbf{U}$ & & & \\
\hline B road-tailed llumingbird & Selasphorus platycercus & $\mathbf{U}$ & $\mathbf{u}$ & $\mathbf{U}$ & $\mathbf{U}$ & & & \\
\hline Rufous Hummingbird. & Selasphorus rufus & $\mathbf{U}$ & $\mathbf{U}$ & $\mathbf{U}$ & $\mathbf{U}$ & & & \\
\hline Belted Kingfisher & Megaceryle alcyon & II & H & $\mathbf{H}$ & M & & & $x$ \\
\hline
\end{tabular}


TABLE 10. (continued)

\begin{tabular}{|c|c|c|c|c|c|c|c|c|}
\hline \multirow[b]{2}{*}{ Common Name } & Species & \multicolumn{4}{|c|}{ Relative Abundance ${ }^{\mathrm{a}}$} & \multicolumn{3}{|c|}{ Habitat Types } \\
\hline & Scientific Name & $S_{p}$ & Su & $\mathbf{F a}$ & W1 & 1 & 2 & 3 \\
\hline Comnon Flicker & Colaptes auratus & $\mathbf{M}$ & M & $\mathbf{M}$ & $\mathbf{L}$ & $\mathrm{x}$ & & $\mathbf{x}$ \\
\hline Lewis' Woodpecker & Asyndesmus lewis & $\mathbf{U}$ & $\mathbf{u}$ & $\mathbf{U}$ & $\overline{\mathbf{u}}$ & & & \\
\hline Hairy Woodpecker & Dendrocopos v111osus & $\mathbf{U}$ & u & $\mathbf{u}$ & $\mathbf{u}$ & & & \\
\hline Downy Woodpecker & Dendrocopos pubescens & $\mathbf{P}$ & $\mathbf{P}$ & $\mathbf{P}$ & $\mathbf{P}$ & & & \\
\hline Eastern Kingbird & Tyrannus tyraunus & $\mathbf{M}$ & $M$ & L & $\mathbf{L}$ & & $\mathrm{x}$ & $\mathrm{x}$ \\
\hline Western Kingbird & Tyrannus verticalis & $M$ & M & $\mathbf{L}$ & I. & & $x$ & $\mathrm{x}$ \\
\hline Ash-throated Flycatcher & Mylarchus cinerascens & $\mathbf{U}$ & $\mathbf{U}$ & $\mathbf{U}$ & $\mathbf{U}$ & & & \\
\hline Say's Phoebe & Sayornis saya & $\mathbf{P}$ & $\mathbf{p}$ & $\mathbf{P}$ & $\mathbf{P}$ & & & \\
\hline Tratli's Flycatcher & Einpidonax traillii & $\mathbf{P}$ & $\mathbf{P}$ & $\mathbf{P}$ & $\mathbf{P}$ & & & \\
\hline Hammond's Flycatcher & Empidonax hammondi1 & $\mathbf{U}$ & u & u & $\mathbf{u}$ & & & \\
\hline Dusky Flycatcher & Empidonax oberholseri & $\mathbf{u}$ & $\mathbf{u}$ & $\mathbf{U}$ & $\mathbf{U}$ & & & \\
\hline Western Wood Pewee & Contopus sordidulus & $\mathbf{U}$ & $\mathbf{U}$ & $\mathbf{U}$ & $\mathbf{U}$ & & & \\
\hline Olive-sided Flycatcher & Nuttallornis borealis & $\mathbf{P}$ & $\mathbf{P}$ & $\mathbf{P}$ & $\mathbf{p}$ & & & \\
\hline Horned Lark & Bremophila alpestris & $M$ & M & $M$ & $M$ & & $\mathrm{x}$ & \\
\hline Barn Swallow & Hirundo rustica & $\mathbf{L}$ & L & L & $\mathbf{P}$ & & $\mathrm{x}$ & \\
\hline cliff Swallow & Petrochelidon pyrrhonota & H & H & H & $\mathbf{p}$ & & $x$ & $x$ \\
\hline Violet-green Swallow & Tachycineta thalassina & L & L & L & $\mathbf{P}$ & & $\mathrm{x}$ & \\
\hline Tree Swallow & Iridoprocie bicolor & L & $\overline{\mathrm{L}}$ & L & $\mathbf{P}$ & & & $\mathbf{x}$ \\
\hline Bank Swallow & Riparia riparia & $\mathrm{L}$ & $\mathbf{L}$ & I. & P & & $x$ & \\
\hline Rough-winged Swallow & Stelgidopteryx ruftcollis & L. & $\mathbf{L}$ & I. & $\mathbf{P}$ & & $\mathrm{X}$ & \\
\hline Steller's Jay & Cyanocitta stelleri & $\mathbf{L}$ & $\mathbf{L}$ & $\mathbf{L}$ & $\mathbf{L}$ & $\mathbf{x}$ & & \\
\hline Gray Jay & Perisoreus canadens is & $\mathbf{U}$ & $\mathbf{U}$ & $\mathbf{U}$ & $\mathbf{U}$ & & & \\
\hline B lack-bill ed Magpie & Pica pica & H & $\mathbf{H}$ & H & II & $\mathrm{x}$ & $\mathbf{x}$ & $\mathbf{X}$ \\
\hline Common Raven & $\overline{\text { Corvus corax }}$ & M & $\mathbf{M}$ & $\mathbf{M}$ & M & $\mathrm{x}$ & $\mathrm{x}$ & \\
\hline Common Crow & Corvus brachyrhynchos & M & M & M & $\mathbf{L}$ & & $\mathrm{x}$ & $\mathbf{x}$ \\
\hline
\end{tabular}


TABLE 10. (continued)

\begin{tabular}{|c|c|c|c|c|c|c|c|c|c|}
\hline \multicolumn{2}{|c|}{ Species } & \multicolumn{5}{|c|}{ Relative Abundance- } & \multicolumn{3}{|c|}{ Habitat Types $\stackrel{b}{-}$} \\
\hline Common Name & Scientific Name & $\mathbf{S p}$ & & Su & $\mathbf{F a}$ & W1 & 1. & 2 & 3 \\
\hline Black-capped Chickadee & Parus atricapillus & $\mathbf{u}$ & & $\mathbf{u}$ & $\mathbf{U}$ & $\mathbf{U}$ & & & \\
\hline Dipper & Cinclus mexicanus & $\mathbf{M}$ & & M & $\mathbf{M}$ & $\mathbf{L}$ & & & $x$ \\
\hline White-breasted Nuthatch & Sitta carolinensis & $\mathbf{u}$ & & $\mathbf{U}$ & $\mathbf{U}$ & $\mathbf{u}$ & & & \\
\hline Brown Creeper & Certhia familiaris & $\mathbf{P}$ & & $\mathbf{P}$ & $\mathbf{P}$ & $\mathbf{P}$ & & & \\
\hline House Wren & Troglodytes aedon & $\mathbf{L}$ & & $\mathbf{L}$ & $\mathbf{L}$ & $\mathbf{L}$ & & $\mathrm{X}$ & $\mathrm{x}$ \\
\hline Long-billed Marsh Wren & Telmatodytes palutris & $\mathbf{P}$ & & $\mathbf{P}$ & $\mathbf{P}$ & $\mathbf{P}$ & & & \\
\hline Canyon Wren & Catherpes mexicanus & $\mathbf{p}$ & & $\mathbf{P}$ & $\mathbf{p}$ & $\mathbf{P}$ & & & \\
\hline Gray Catbird & Dumetella carolinens is & $\mathbf{L}$ & . & L & L. & $\mathbf{P}$ & & & $x$ \\
\hline Sage Thrasher & Oreoscoptes montanus & $\mathrm{L}$ & & $\mathbf{L}$ & L & P & $\mathrm{x}$ & $\mathrm{x}$ & $\mathrm{x}$ \\
\hline Robin & Turdus migratorius & $\mathbf{H}$ & & $\mathbf{H}$ & H & L & $\mathrm{x}$ & $x$ & $\mathrm{x}$ \\
\hline Hermit Thrush & Hyloc1ch1a guttata & $\mathbf{L}$ & & L. & $\mathrm{L}$ & $\mathbf{P}$ & & & $\mathrm{x}$ \\
\hline Swainson's Thrush & Ilylocich1a ustulata & I. & & L & L & $\mathbf{p}$ & & & $\mathrm{x}$ \\
\hline Veery & Ilylocichla fuscescens & $\mathbf{U}$ & & $\mathbf{U}$ & $\mathbf{U}$ & U & & & \\
\hline Mountain Bluebird & Stal ia currucoides & $\mathbf{L}$ & & $\mathbf{L}$ & $\mathbf{H}$ & $\mathbf{P}$ & $\mathrm{x}$ & & \\
\hline 'Townsend's Solltare & Myadestes townsend & $\mathbf{U}$ & & $\mathbf{u}$ & $\mathbf{U}$ & U & & & \\
\hline Golden-crowned Kinglet & Regulus satrapa & $\mathbf{U}$ & & $\mathbf{u}$ & $\mathbf{U}$ & $\mathbf{u}$ & & & \\
\hline Ruby-crowned Kinglet & Regulus calendula & $\mathbf{U}$ & & $\mathbf{U}$ & $\mathbf{u}$ & $\mathbf{u}$ & & & \\
\hline Water Pipit & Antlus spinoletta & $\mathbf{U}$ & & $\mathbf{U}$ & $\mathbf{U}$ & $\mathbf{U}$ & & & \\
\hline Bohemian Waxwing & Bombyc111a garrula & $\mathrm{L}$ & & $\mathbf{p}$ & $\mathbf{L}$ & $\mathbf{I}$ & & & $\mathrm{x}$ \\
\hline Cedar Waxwing & Bombycilla cedrorum & I. & & $\mathrm{P}$ & L. & $\mathbf{L}$ & & & $\mathrm{X}$ \\
\hline Northern Shrike & Ianius excubitor & $\mathbf{M}$ & & $\mathbf{L}$ & $\mathbf{L}$ & I. & & $\mathrm{x}$ & \\
\hline Loggerhead Shrike & Lanius ludovicianus & $M$ & & $\mathbf{L}$ & $\mathbf{L}$ & L & & $x$ & $x$ \\
\hline Starling & Sturnus vulgaris & HI & & II & II & 11 & $\mathrm{x}$ & $\mathrm{x}$ & $\mathrm{x}$ \\
\hline Red-eyed Vireo & Vireo ol ivaceus & $\mathbf{U}$ & & $\mathbf{u}$ & $\mathbf{U}$ & $\mathbf{U}$ & & & \\
\hline Warbling Vireo & V1reo gilvus & $\mathbf{L}$ & & $\mathbf{L}$ & $\mathbf{L}$ & $\mathbf{P}$ & & & $\mathrm{x}$ \\
\hline
\end{tabular}


TABLE 10. (continued)

\begin{tabular}{|c|c|c|c|c|c|c|c|c|}
\hline \multirow[b]{2}{*}{ Common Name } & pecies & \multicolumn{2}{|c|}{ Relative } & \multicolumn{2}{|c|}{ bundance ${ }^{a}$} & \multicolumn{3}{|c|}{ Habitat Types } \\
\hline & Scientific Name & $\mathrm{sp}$ & Su & $\mathbf{F a}$ & W1 & 1 & 2 & 3 \\
\hline Orange-crowned Warbler & Verinivora celata & $\mathbf{p}$ & $\mathbf{P}$ & $\mathbf{P}$ & $\mathbf{p}$ & & & \\
\hline Nashville Warbler & Vernivora ruficapilla & $\mathbf{U}$ & U & $\mathbf{U}$ & $\mathbf{U}$ & & & \\
\hline Yellow Warbler & Dendroica petechia & L & I. & $\mathrm{L}$ & $\vec{p}$ & & & $\mathrm{x}$ \\
\hline Yellow-rumped Warbler & Dendrolca coronata & U & $\mathbf{u}$ & $\mathbf{U}$ & $\mathbf{U}$ & & - & \\
\hline Townsend's Warbler & Dendrolca townsendi & $\mathbf{u}$ & $\mathbf{U}$ & $\mathbf{U}$ & $\mathbf{U}$ & & & \\
\hline MacGillivray's Warbler & Oporornis tolmiei & $\mathbf{u}$ & $\mathbf{u}$ & $\mathbf{U}$ & $\mathbf{u}$ & & & \\
\hline Common Yellowthroat & Geothlypis trichas & $\mathbf{L}$ & $\mathbf{L}$ & $\mathbf{L}$ & $\mathbf{p}$ & & & $x$ \\
\hline Wilson's Warbler & Wilsonia pusilla & $\mathbf{U}$ & $\mathbf{u}$ & $\mathbf{U}$ & $\mathbf{U}$ & & & \\
\hline Yellow-breasted Chat & Icteria virens & $\mathbf{U}$ & $\mathbf{u}$ & $\mathbf{U}$ & $\mathbf{U}$ & & & \\
\hline House Sparrow & Passer domesticus & $\mathbf{M}$ & M & M & M & $\mathbf{x}$ & $\mathrm{x}$ & \\
\hline $\begin{array}{l}\text { Western Meadowlark } \\
\text { Yel low-headed B lackbird }\end{array}$ & $\frac{\text { Sturnella neglecta }}{\text { Xanthocephalus }}$ & II & H & H & M & $\mathrm{x}$ & $\mathbf{x}$ & \\
\hline & xanthocephalus & $\mathbf{M}$ & $\mathbf{M}$ & $\mathbf{M}$ & $\mathbf{P}$ & & $\mathrm{x}$ & $\mathrm{x}$ \\
\hline Red-winged Blackbird & Agelaius phoeniceus & II & II & $\mathbf{H}$ & L & & $\mathbf{x}$ & $\mathrm{x}$ \\
\hline Northern Oriole. & Icterus galbula & U & $\mathbf{U}$ & $\mathbf{U}$ & $\mathbf{U}$ & & & \\
\hline B rewer's Blackbird & Euphagus cyanocephalus & M & $M$ & M & $\mathbf{P}$ & & $\mathrm{x}$ & $\mathrm{x}$ \\
\hline Common Grackle & Quiscalus quiscula & $\mathbf{L}$ & $\mathbf{L}$ & $\mathbf{L}$ & $\mathbf{P}$ & & & $\mathrm{x}$ \\
\hline B rown-headed Cowbird & Molothrus ater & $\mathrm{L}$ & L. & L. & $\mathbf{P}$ & & & $\mathrm{X}$ \\
\hline Western Tanager & PIranga ludoviciana. & L & L. & l. & $\mathbf{P}$ & & $x$ & $\mathrm{x}$ \\
\hline Black-headed Grosbeak & Plieucticus melanocephalus & $\mathbf{L}$ & $\mathrm{l}$ & $\mathrm{L}$ & $p$ & & & $\mathrm{x}$ \\
\hline Lazul1 Bunting & Passerina amoena & $\mathbf{L}$ & $\mathbf{L}$ & $\mathbf{L}$ & $\mathbf{P}$ & & $x$ & $\mathrm{x}$ \\
\hline Livening Grosbeak & Hesperiphona vespertina & $\mathbf{U}$ & $\mathbf{u}$ & $\mathbf{U}$ & $\mathbf{U}$ & & & \\
\hline Cassin's Finch & Carpodacus cassinit & $\mathrm{L}$ & $\mathbf{L}$ & $\mathbf{L}$ & $\mathbf{P}$ & & & $\mathrm{x}$ \\
\hline House Finch & Carpodacus mexicanus & $\mathbf{M}$ & M & $\mathbf{L}$ & $\mathbf{P}$ & & $\mathrm{x}$ & $\mathrm{x}$ \\
\hline Gray-crowned Rosy Finch & Ieucosticte tephrocot is & $\mathbf{P}$ & $\mathbf{P}$ & $\mathbf{P}$ & $\mathbf{P}$ & & & \\
\hline Black Rosy Finch. & Leucosticte atrata & $\mathbf{u}$ & $\mathbf{U}$ & $\mathbf{U}$ & $\mathbf{U}$ & & & \\
\hline
\end{tabular}


TABLE 10. (continued)

\begin{tabular}{|c|c|c|c|c|c|c|c|c|}
\hline \multicolumn{2}{|c|}{ Spectes } & \multicolumn{4}{|c|}{ Relative Abundance $e^{a}$} & \multicolumn{3}{|c|}{ Habitat Types } \\
\hline Common Name & Sctentif tc Naine & Sp & Su & $\mathbf{F a}$ & W1 & 1 & 2 & 3 \\
\hline Ainer lcan Goldf inch & Spinus tristis & $\mathbf{L}$ & $\mathbf{L}$ & I. & $\mathbf{P}$ & & $\mathrm{x}$ & $x$ \\
\hline Green-tailed Towhee & Chlorura chlorura & $\mathbf{u}$ & $\mathbf{u}$ & $\mathbf{U}$ & $\mathbf{U}$ & & & \\
\hline Rufous-sided Towher & P1pilo erythrophtha linus & $\mathbf{L}$ & $\mathbf{L}$ & $\mathbf{L}$ & $\mathbf{P}$ & & & $\mathrm{x}$ \\
\hline Savanual Sparrow & Passerculus sandwichensis & I. & $\mathbf{L}$ & $\mathbf{L}$ & $\mathbf{P}$ & & $\mathbf{x}$ & \\
\hline Grasshopper Sparrow & Anmodrainus savannarum & $\mathrm{L}$ & L & L. & $\mathbf{P}$ & & & \\
\hline Vesper Sparrow & Pooecetes gramineus & $\mathbf{P}$ & $\mathbf{P}$ & $\mathbf{P}$ & $\mathbf{P}$ & & & \\
\hline Lark Sparrow & Chondes tes grainmacus & L & L. & $\mathbf{L}$ & $\mathbf{P}$ & & & \\
\hline Black-throated Sparrow & Amplisplza bilineata & $\mathrm{p}$ & $\mathbf{p}$ & $\mathbf{P}$ & $\mathbf{p}$ & & & \\
\hline Sage Sparrow & Ainphispiza belid & $\mathbf{P}$ & $\mathbf{P}$ & $\mathbf{P}$ & P & $\mathrm{x}$ & & \\
\hline Dark-eyed Junco & Junco hyeina1is & H & il & $\mathbf{H}$ & $M$ & $\mathrm{x}$ & $\mathrm{x}$ & $\mathrm{x}$ \\
\hline Tree Sparrow & Splze11a arborea & U & $\mathbf{u}$ & $\mathbf{u}$ & $\mathbf{U}$ & & & \\
\hline Chipping Sparrow & Spize11a passerina & L & $\mathbf{L}$ & I. & $\mathrm{P}$ & & & $x$ \\
\hline Brewer's Sparrow & Spize11a breweri & $\mathbf{L}$ & $\mathbf{L}$ & l. & $\mathbf{P}$ & & & \\
\hline White-crowned Sparrow & Zonotrich La lencophrys & l. & L. & i. & I. & & $\mathrm{x}$ & $x$ \\
\hline Fox Sparrow & Passere11a 111aca & $\mathbf{U}$ & $\mathbf{U}$ & $\mathbf{u}$ & $\mathbf{U}$ & & & \\
\hline Lincoln's Sparrow & Melospiza lincolnii & U & $\mathbf{U}$ & $\mathbf{U}$ & $\mathbf{U}$ & & & \\
\hline Song Sparrow & Melospiza melodia & $\mathrm{L}$ & L. & L & p & & & $x$ \\
\hline Snow Bunting & Plectrophenax nivalis & A & $\mathrm{A}$ & A & p & & & \\
\hline
\end{tabular}

a $_{\text {Key }}$ to Relative Abundance: $\mathrm{H}=\mathrm{High}, \mathrm{M}=$ Mediun, $\mathrm{L}=\mathrm{L}$ ow, $\mathrm{A}=\mathrm{Absent}, \mathrm{P}=$ Population level unknown, $\mathrm{U}=\mathrm{Presence}$ unknown.

Wey to llabltat Types: 1=Sagebrush, 2=Non-irrigated Farm, J=Strean Side. 
TABLE 11. RELATIVE ABUNDANCE AND HABITAT LISTINGS FOR MAMMALS IN THE CRANE CREEK KGRA

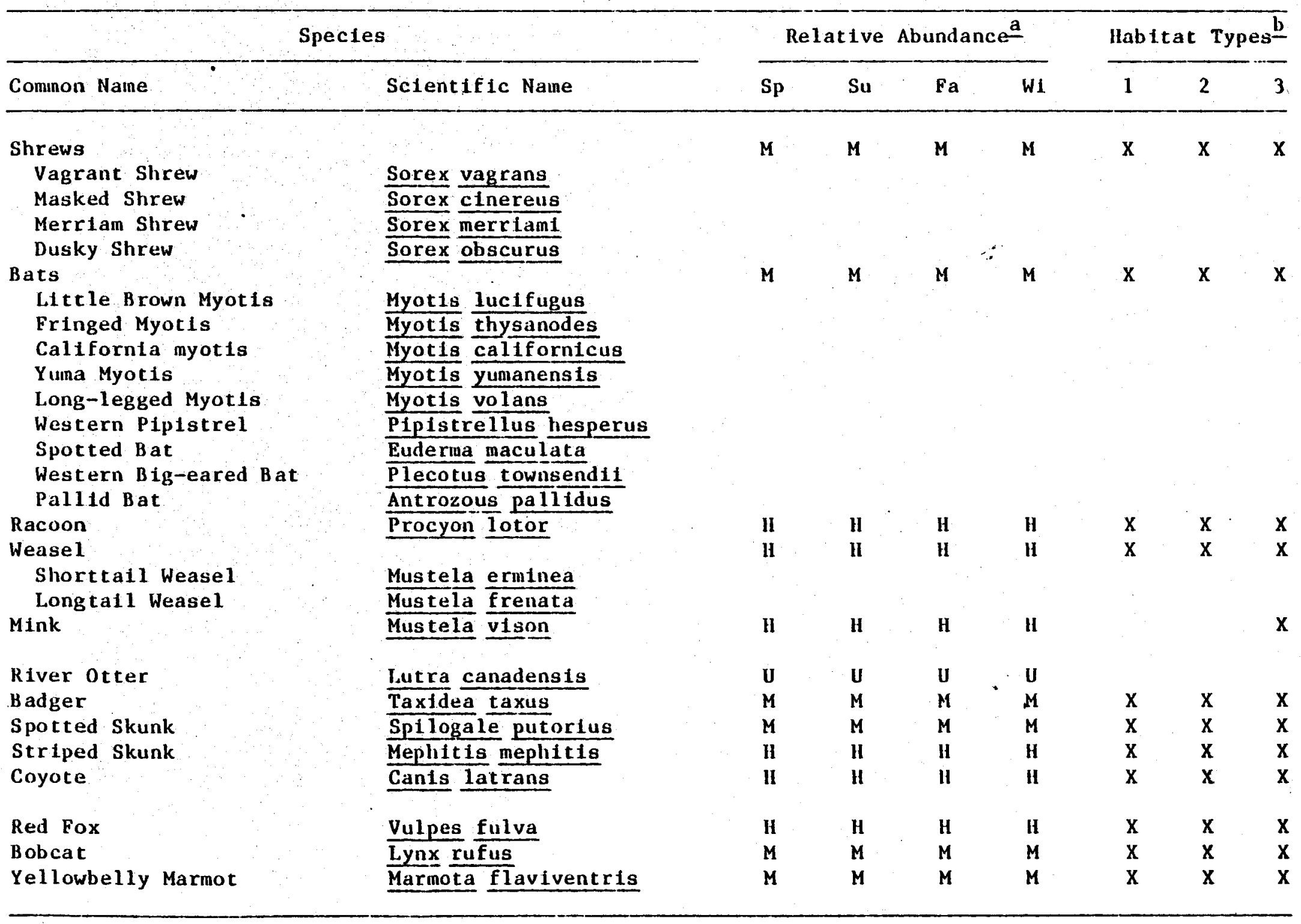


TABLE 11. (continued)

\begin{tabular}{|c|c|c|c|c|c|c|c|c|}
\hline \multicolumn{2}{|c|}{ Species } & \multicolumn{4}{|c|}{ Relative Abundance ${ }^{a}$} & \multicolumn{3}{|c|}{ Habticat Types } \\
\hline Common Name & Scientific Name & Sp & Su & $\mathbf{F a}$ & W1 & 1 & 2 & 3 \\
\hline Townsend Ground Squirrel & Spermophtlus townsendi & $\mathbf{L}$ & L. & $\mathbf{L}$ & $\mathbf{L}$ & & $\mathbf{x}$ & \\
\hline Idaho Ground Squirrel & $\overline{\text { Sperimophilus brunneus }}$ & $\mathbf{P}$ & $\mathbf{P}$ & $\mathbf{P}$ & $\mathbf{P}$ & & & $\mathbf{x}$ \\
\hline Columbia Ground Squirrel & Spermophilus columblanus & $\mathbf{M}$ & $\mathbf{M}$ & $\mathbf{M}$ & $M$ & $\mathbf{X}$ & $\mathbf{x}$ & $\mathbf{x}$ \\
\hline Least Chipmunk & Eutamlas mintmus & H & $\mathbf{H}$ & H & H & $\mathbf{x}$ & $\mathbf{x}$ & $\mathbf{x}$ \\
\hline Fox Squirrel & Scturus niger & $\mathbf{H}$ & H & HI & II & & & $\mathbf{x}$ \\
\hline Northern Pocket Gopher & Thoinomys talpotdes &.$M$ & M & $\mathbf{M}$ & M & $\mathrm{x}$ & $\mathbf{x}$ & $\mathbf{x}$ \\
\hline Townsend Pocket Gopher & Thomoinys townsendi & $\mathbf{P}$ & $\mathbf{P}$ & $\mathbf{P}$ & $\mathbf{P}$ & & & $\mathbf{x}$ \\
\hline Great'Basin Pocket Mouse & Perognathus parvus & $\mathbf{P}$ & $\mathbf{P}$ & $\mathbf{P}$ & $\mathbf{P}$ & $\mathbf{X}$ & & \\
\hline B eaver & Castor canadensis & H & H & HI & H & $\mathbf{X}$ & & $\mathbf{x}$ \\
\hline Western llarvest Mouse & Reithrodontonys megalotis & M & M & M & $\mathbf{M}$ & & $\mathrm{x}$ & $\mathbf{x}$ \\
\hline Deer Mouse & Peronyscus mantculatus & $\mathbf{H}$ & lI & $\mathbf{H}$ & H & $\mathbf{X}$ & $\mathbf{x}$ & $\mathbf{x}$ \\
\hline Northern Grasshopper Mouse & Onychomys lellcogaster & $\mathrm{L}$ & L & l. & L. & $\mathrm{X}$ & & \\
\hline Bushytail Woodrat & Neotoma c1nerea & $\mathbf{L}$ & I. & $\mathbf{L}$ & $\mathbf{L}$ & $\mathrm{X}$ & $\mathbf{x}$ & $\mathbf{x}$ \\
\hline Mountain Vole & Microtus montanus & $\mathbf{L}$ & $\mathbf{l}$ & L. & I. & & & $\mathbf{x}$ \\
\hline Longtatl Vole & Microtus longtcaudus & $\mathbf{P}$ & $\mathbf{P}$ & $\mathbf{P}$ & $\mathbf{P}$ & & & $x$ \\
\hline Richardson Vole & Microtus richardsont & $\mathbf{U}$ & U & $\mathbf{U}$ & $\mathbf{U}$ & & & \\
\hline Muskrat & Ondatra zibethica & H & $\mathbf{H}$ & II & H & & & $\mathrm{x}$ \\
\hline Western Jumping Mouse & Zapus princeps & $\mathbf{L}$ & I. & $\mathbf{L}$ & $\mathbf{L}$ & $x$ & . & $\mathbf{x}$ \\
\hline Porcupine & Erethizon dorsatum & M & $M$ & $M$ & $M$ & $x$ & $\mathbf{x}$ & $\mathbf{X}$ \\
\hline Whitetall Jackrabbit & Lepus townsend 1 & $\mathbf{M}$ & $\mathbf{M}$ & $\mathbf{M}$ & $\mathbf{M}$ & $\mathbf{x}$ & $\mathbf{x}$ & \\
\hline Blacktail Jackrabbit & Lepus californicus & $\mathbf{H}$ & u & $\mathbf{H}$ & U & $\mathbf{x}$ & $\mathrm{x}$ & \\
\hline Mountain Cottonta1l & Sylvilagus nuttalli & $M$ & $M$ & $M$ & M & $X$ & $\mathbf{x}$ & $\mathbf{x}$ \\
\hline Pygmy Rabblt & Sylvilagus idahoensis & $\mathbf{L}$ & $\mathbf{L}$ & $\mathbf{L}$ & $\mathbf{L}$ & & $\mathbf{x}$ & $\mathbf{x}$ \\
\hline Mule Deer & Odocolleus hemionus & $\mathrm{H}$ & II & ll & H & 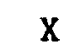 & $x$ & $x$ \\
\hline Pronghorn Antelope & Antilocapra americana & M & $\mathbf{M}$ & $\mathbf{M}$ & $M$ & $\mathrm{X}$ & $\mathrm{x}$ & \\
\hline
\end{tabular}

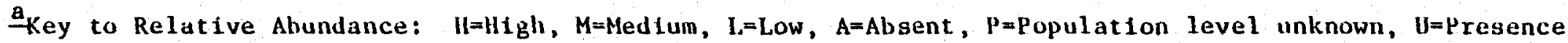
unknown.

bey to llabitat Types: l=Sagebrush, 2=Non-1rrigated Farm, 3=Stream Side. 
These data sources are summarized as follows for:

1. Amphibians and reptiles, References $19,20,21,22$, and 23.

2. Birds, References $19,22,23,24,25$, and 26 .

3. Mammals, References $19,22,23,27$, and 28 . 站

Tables 8 through 11 represent a convenient compilation of the information obtained. Since numerous techniques were used (sometimes little more than guessing about distribution) to gather these data, it seemed better to simply assign their numbers to some "relative abundance" category. This was the best way to avoid encouraging conclusions of the reader that could not be supported with data. Where blanks occur in Tables 8 through 11, data were either unavailable or were too questionable.

Species of special concern (key species) presented in Table 12, have been classified according to whether they are considered game species, furbearer or of extended concern because of restricted range, specific habitat requirements, population numbers so low that they may be easily eliminated from Idaho, and/or whether they are threatened or endangered. Because these species have received more consideration in past work and more data are available, Table 12 should be considered rather accurate.

Distributions of some species of concern, listed in Table 12, are plotted in Figures 18 through 26, demonstrating their proximities to the KGRAs. Species not included in these figures were either ubiquitous or their distributions were unknown, such as would be expected for many of the nongame and migratory species. Data included were taken from "Idaho Environmental Overview" 29 and adopted for the county maps. The data accuracy must be accepted cautiously. Local habitat variation not included in the overall diagrams will create many exceptions to what is illustrated, providing sufficient research is done. 
TABLE 12. SPECIAL CONCERN SPECIES OF THE KGRA

\begin{tabular}{|c|c|c|c|c|c|c|c|c|}
\hline \multicolumn{2}{|c|}{ Species } & \multicolumn{4}{|c|}{ KGRA Areas ${ }^{\mathrm{a}}$} & \multicolumn{3}{|c|}{ Special Concern Category } \\
\hline Common Name & Scientific Name & B & M & c & v & Game & Furbearer & Extended Concern \\
\hline \multicolumn{9}{|l|}{ Mamina 1s: } \\
\hline Black Bear & Ursus americanus & & ic & & $\mathbf{x}$ & $x$ & & \\
\hline Raccoon & Procyon lotor & $\mathbf{x}$ & $\mathrm{x}$ & $\mathrm{x}$ & $\mathrm{x}$ & & $\mathrm{x}$ & \\
\hline Marten & Martes americana & & & & $\mathrm{x}_{\mathrm{c}}$ & & $\mathrm{x}$ & \\
\hline Fisher & Martes $\overline{\text { Pennant I }}$ & & & & I & & & $\mathbf{x}$ \\
\hline Mink & Mustela vison & $\mathrm{x}$ & $\mathbf{x}$ & $\mathbf{x}$ & $\mathrm{x}$ & & $\mathrm{x}$ & \\
\hline Wolverine & Gulo luscus & & & & Ic & & & $\mathrm{x}$ \\
\hline Gray Wolf & Canis lupus & & & & $j$ & & & $\ddot{\mathrm{XE}}$ \\
\hline Red Fox & Vulpes fulva & $x^{2}$ & $\mathrm{x}$ & $\mathrm{x}$ & $\mathrm{x}$ & & $\mathrm{x}$ & \\
\hline K1t Fox & Vulpes macrotis & I드. & & & & & & $\mathrm{x}$ \\
\hline Mountain Lion & Felis concolor & & $\mathrm{x}$ & & $\mathrm{x}$ & $\mathrm{x}$ & & \\
\hline Canada Lynx & Lynx canadensis & & & & $\mathrm{x}$ & & $\mathrm{x}$ & $\mathbf{x}$ \\
\hline Bobcat & Lynx rufus & $\mathbf{x}$ & $\mathrm{x}$ & $x$ & $\mathrm{x}$ & & $\mathrm{x}$ & $\mathrm{x}$ \\
\hline Idaho Ground Squitrel & Spermophilus brunneus & & & $\ddot{x}$ & & & & $\mathrm{x}$ \\
\hline Beaver & Castor canadensis & $x$ & $\mathrm{x}$ & $\mathbf{x}$ & $\mathrm{x}$ & & $\mathbf{x}$ & \\
\hline Muskrat & Ondatra zibetlifca & $\mathrm{x}$ & $\mathbf{x}$ & $\mathrm{x}$ & $x$ & & $\mathrm{x}$ & \\
\hline Mountain Cottontall & Sylvilagus nuttalle & $\mathrm{x}$ & $\mathbf{x}$ & $\mathbf{x}$ & $\mathrm{x}$ & $\mathrm{x}$ & & \\
\hline Pygray Rabbit & Sylvilagus Idahoens is & $\mathrm{x}$ & $\bar{x}$ & $\mathrm{x}$ & & $\mathrm{x}$ & & \\
\hline Elk & Cervus canadensls & ic & $\mathrm{x}$ & & $\mathrm{x}$ & $\mathrm{x}$ & & \\
\hline Mule Deer & Odocolleus hemionus & $\mathrm{x}$ & $\ddot{x}$ & $\mathrm{x}$ & $\mathrm{x}$ & $\ddot{x}$ & & \\
\hline Whitetail Deer & Odocolleus v1rgIn1anus & & & & j도 & $\mathrm{x}$ & & \\
\hline Moose & Alces alces & & & & 1 드 & $\mathrm{x}$ & & \\
\hline Pronghorn Antelope & Ant1locapra americana & $\mathrm{x}$ & $\mathrm{x}$ & $\mathrm{x}$ & & $\mathrm{x}$ & & \\
\hline Mountain Goat & Oreamnos americanus & & & & jec & $\mathrm{x}$ & & \\
\hline Bighorn Sheep & Ovis canadensis & $\mathrm{x}$ & & & & $\mathrm{x}$ & & \\
\hline
\end{tabular}


TABLE 12. (continued)

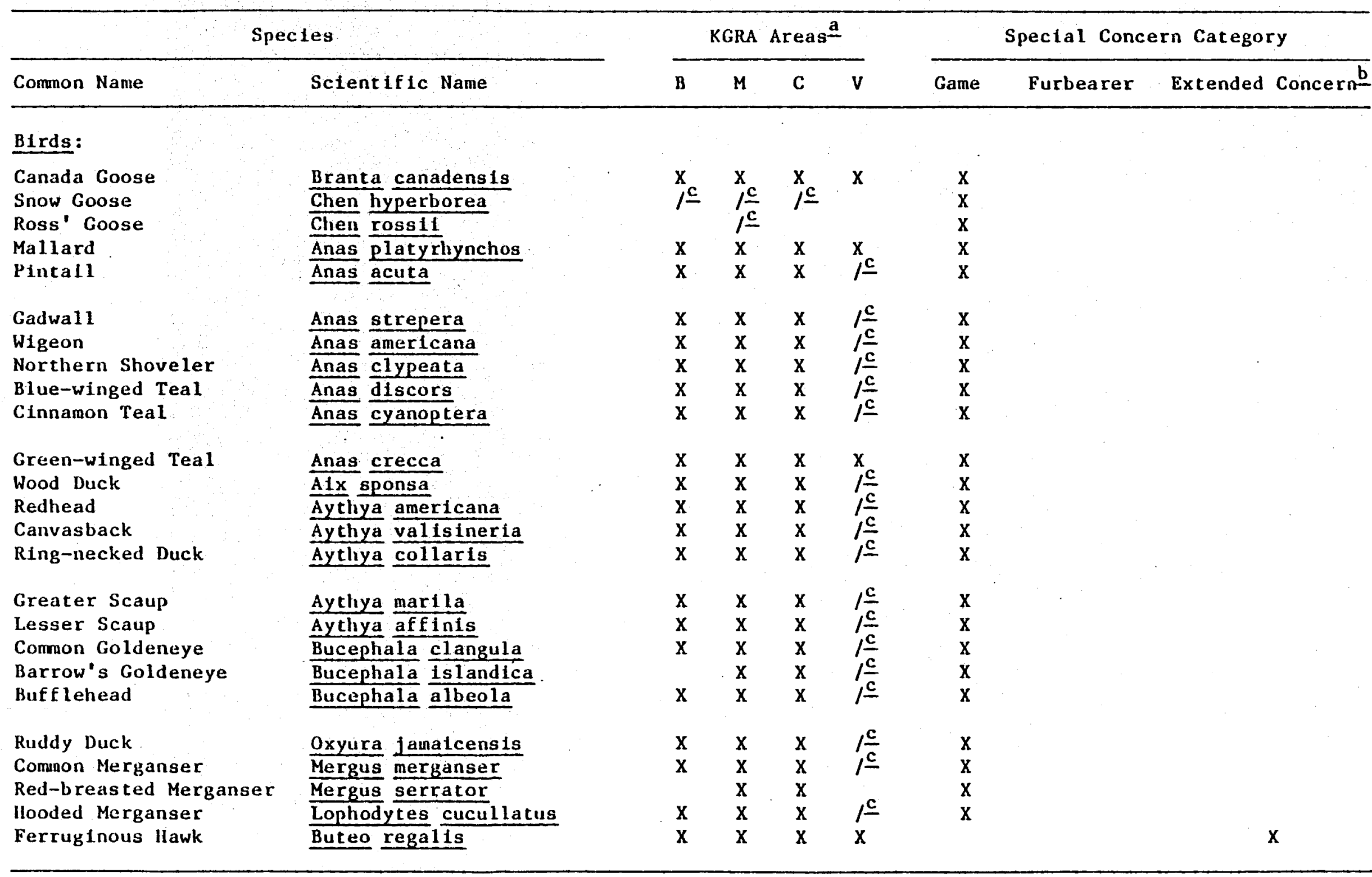


TABLE 12. (continued)

\begin{tabular}{|c|c|c|c|c|c|c|c|c|c|}
\hline \multirow[b]{2}{*}{ Common Name } & Species & \multicolumn{4}{|c|}{ KGRA Areas } & \multicolumn{4}{|c|}{ Special Concern Category } \\
\hline & Scientific Narne & B & $M$ & C & $\mathbf{V}$ & Game & Furbearer & Extended & Concern \\
\hline Bald Eagle & Haltaeetus leucocephalus & $x$ & $\mathbf{x}$ & $\mathbf{x}$ & $\mathbf{x}$ & & & & $\mathbf{E}$ \\
\hline Prairie Falcon & Falco mexicanus & $\mathbf{x}$ & $x$ & $\mathbf{X}$ & & & & & $x$ \\
\hline Peregrine Falcon & $\overline{\text { Falco }} \overline{\text { peregrinus }}$ & $\mathbf{X}$ & $\mathbf{X}$ & & $\mathbf{X}$ & . & & $y$ & $\mathbf{X E}$ \\
\hline W11d Turkey & Meleagris ga1lopavo & & 1 c & & & $\mathbf{X}$ & & & \\
\hline Blue Grouse & Dendragapus obscurus & $\mathbf{X}$ & $\mathbf{X}$ & $\mathrm{X}$ & $\mathbf{X}$ & $\mathbf{x}$ & & & \\
\hline Spruce Grouse & Canachites canadensis & $\mathbf{X}$ & $\mathbf{X}$ & & $x$ & $\mathbf{X}$ & & & \\
\hline Ruffed Grouse & Bonasa umbel1us & & $\mathbf{X}$ & $\mathrm{x}$ & $\mathbf{x}$ & $\mathbf{x}$ & & & \\
\hline Sharp-talled Grouse & Ped1oecetes phasiane11us & & & $\mathrm{x}$ & & $\mathbf{x}$ & & & $\mathrm{x}$ \\
\hline Sage Grouse & Centrocercus urophas lanus & $\mathrm{x}$ & $\mathbf{X}$ & $\mathrm{X}$ & & $\mathbf{x}$ & & & \\
\hline Bobwhite & Colinus virglnianus & $\mathrm{X}$ & & & & $\mathbf{x}$ & & & $\mathbf{X}$ \\
\hline California Quail & Lophortyx californicus & $\mathrm{x}$ & $\mathbf{x}$ & $\mathrm{X}$ & & $\mathbf{X}$ & & & $\mathbf{x}$ \\
\hline Mounta1n Quall & Oreortyx pictus & & $\mathbf{X}$ & & & $\mathbf{X}$ & & & \\
\hline Ring-necked Pheasant & Phasianus colchicus & $\mathrm{X}$ & $\mathbf{X}$ & $\mathbf{X}$ & & $\mathbf{X}$ & & & \\
\hline Chukar & Alectorls chukar & $\mathrm{x}$ & $\mathbf{x}$ & $x$ & $\mathbf{X}$ & $\mathbf{X}$ & & & \\
\hline Gray Partridge & Perdix perdix & $\mathrm{X}$ & $\mathrm{X}$ & $X$ & & $\mathbf{X}$ & & & \\
\hline Ainerlcan Coot & Fullca americana & $1 \frac{c}{c}$ & $1 \frac{c}{c}$ & $x$ & & $\mathrm{X}$ & & & \\
\hline Common Snipe & Cape11a gallinago & ic & je & $\mathrm{X}$ & I드. & $\mathbf{x}$ & & & \\
\hline Mourning Dove & Zenaidura macroura & $\mathbf{X}$ & $\mathbf{X}$ & $\mathrm{X}$ & $\mathbf{X}$ & $\mathbf{X}$ & & & \\
\hline Rept 1les: & & & & & & & & $\cdot$ & \\
\hline Ringneck Snake & Diadophts punctatus & $\mathrm{x}$ & & & & & & & $\mathbf{X}$ \\
\hline Lorig-nosed Snake & Rhinoche 1 lus lecontei & $\mathrm{X}$ & $\mathrm{X}$ & & & & & & $\mathbf{X}$ \\
\hline Western Ground Snake & Sonora semtanuulata & $\mathrm{x}$ & $\mathbf{x}$ & $\mathbf{X}$ & & & & & $\mathbf{X}$ \\
\hline Night Snake & Iypsiglena torquata & $x$ & $\mathbf{X}$ & & & & & & $\mathbf{X}$ \\
\hline
\end{tabular}

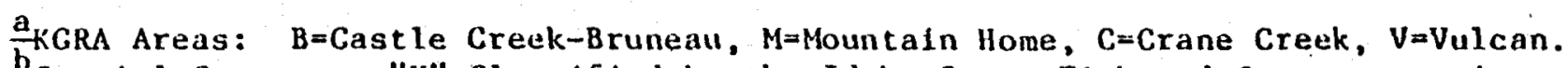

bspectal Concern: " $X "=C l a s s i f$ led by the Idaho State Fish and Game as spectes whose restricted range, specific habitat requirements and/or population numbers make them vulnerable to elimination from the state.

"E"=Indicates species that are federally protected as "Endangered Species", according to the Endangered Species Act (Revised List; August, 1978).

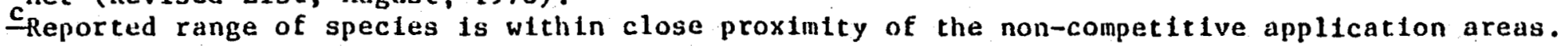




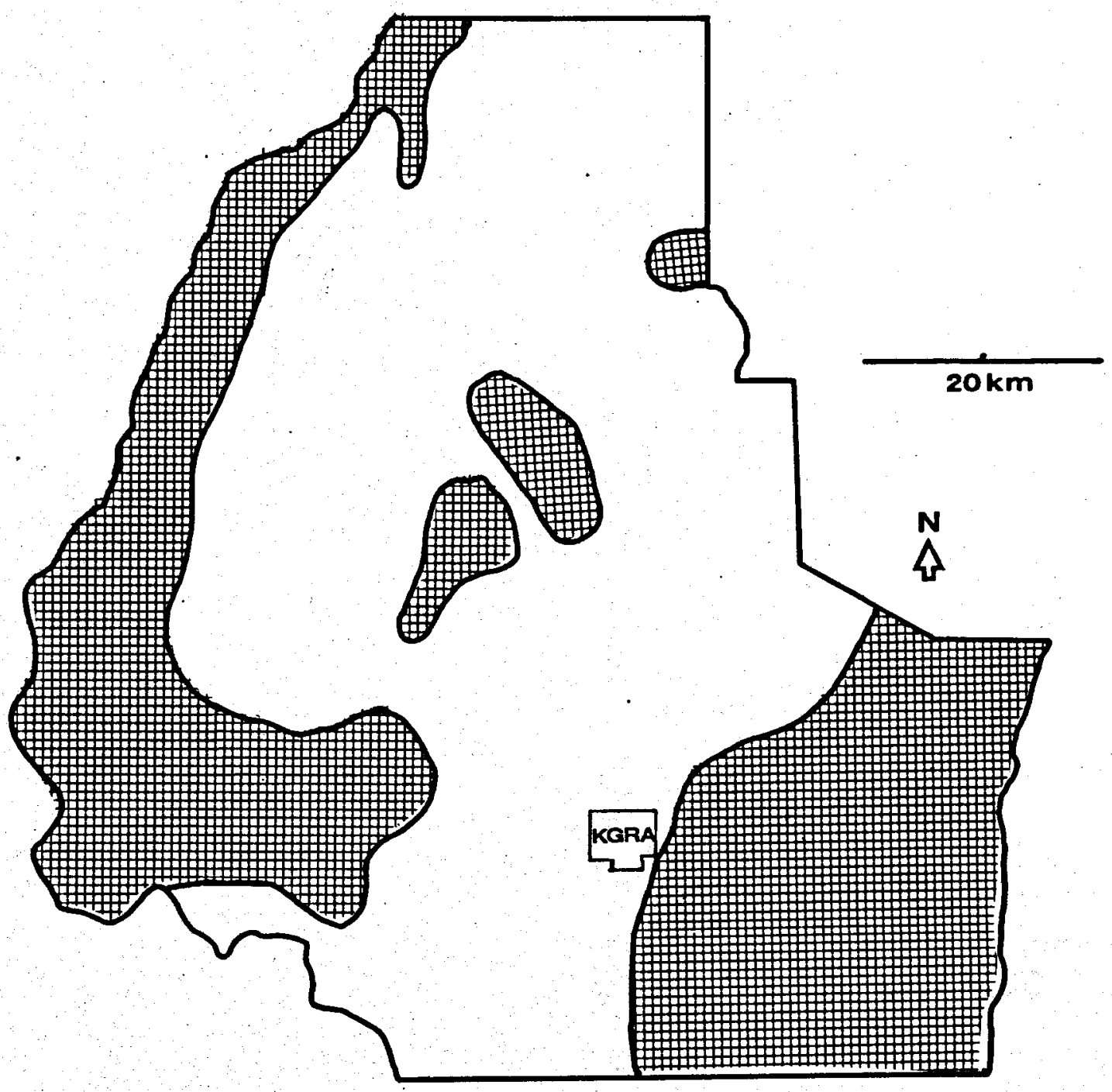

Figure 18. Distribution of Mule Deer (0docoileus hemionus) wintering habitat within Washington County, Idaho, generally illustrating its proximity to the Crane Creek KGRA. 


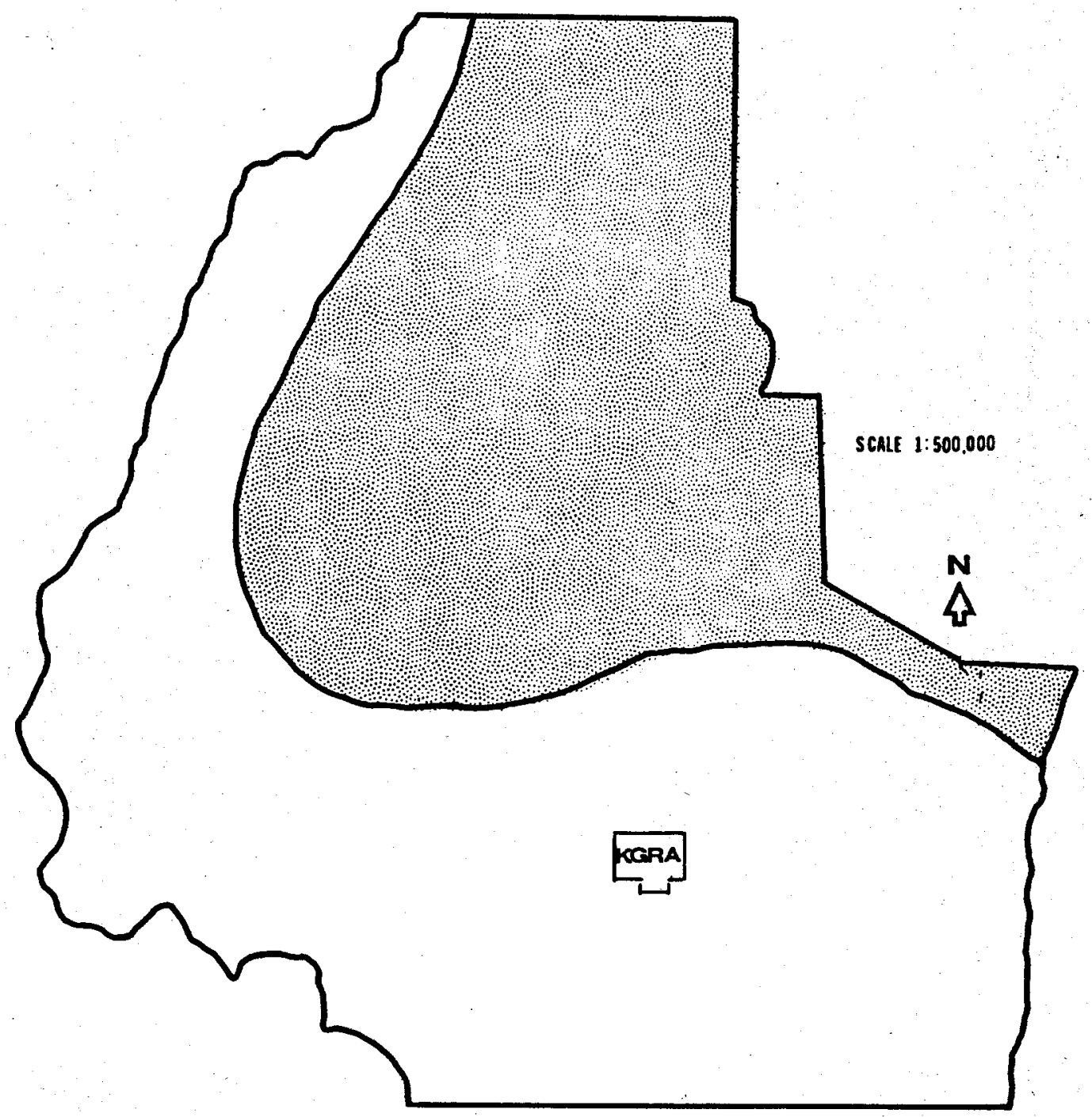

Figure 19. Distribution of Elk (Ceruus Canadensis) habitat within Washington County, Idaho, generally illustrating its proximity to the Crane Creek KGRA. 


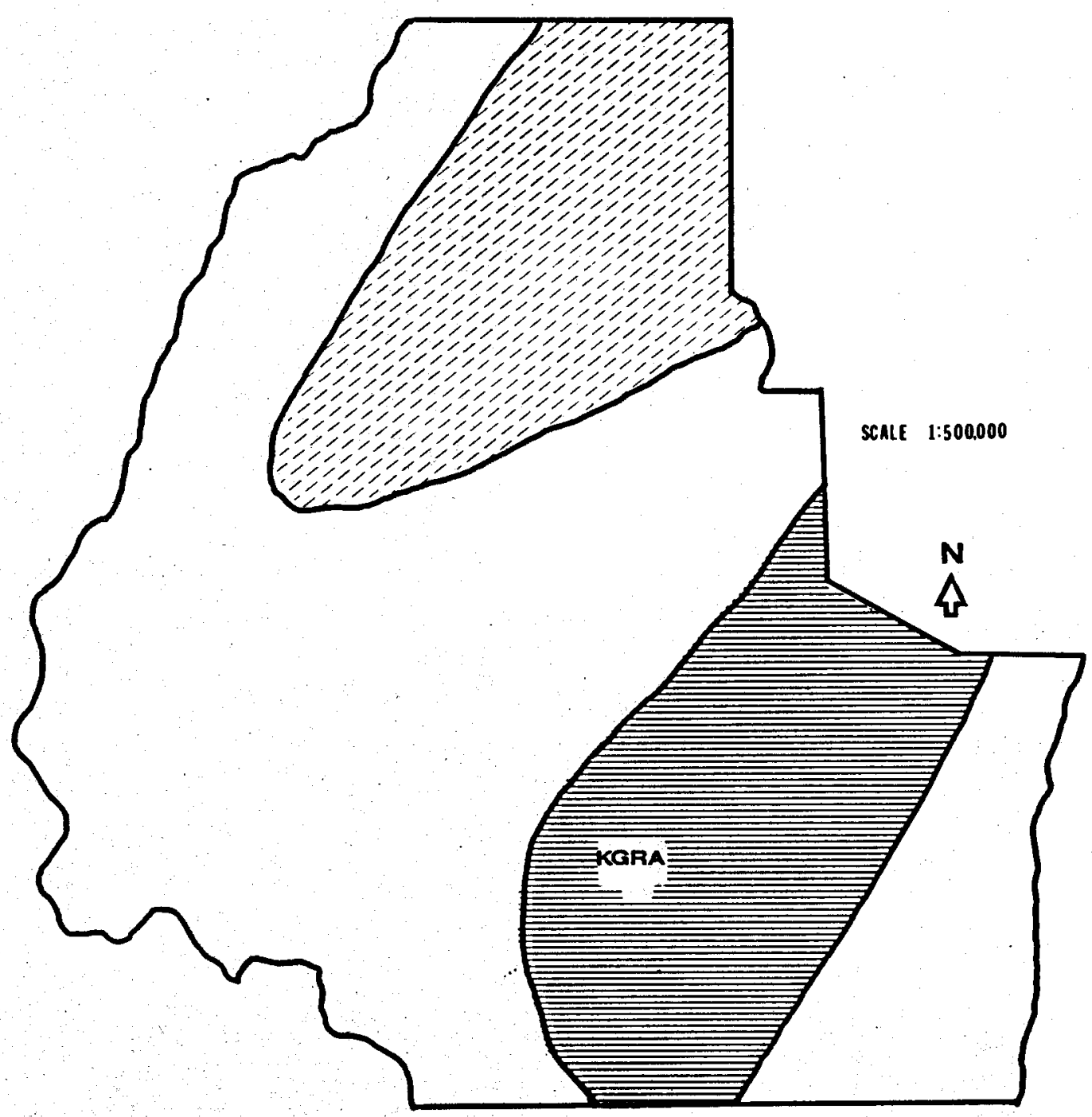

Figure 20. Distributions of Black Bear (Ursus americanus) habitat (cross-hatched) and Pronghorn (Antilocarpa americana) habitat (horizontal lines) within Washington County, Idaho, generally illustrating its proximities to the Crane Creek KGRA. 


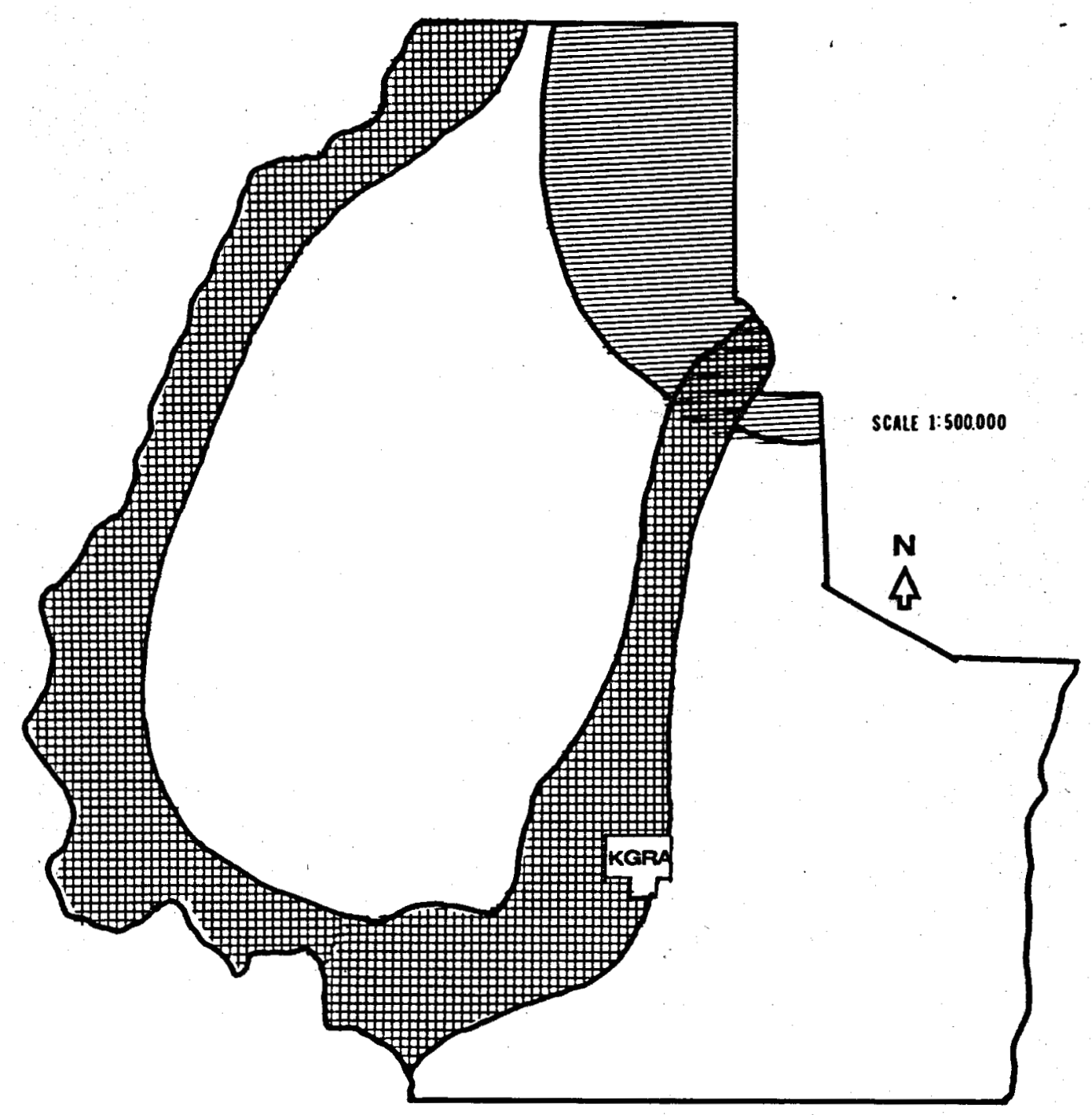

Figure 21. Distributions of California Quail (Lophortyx californicus) habitat (cross-hatched) and Mountain Lion (Felis concolor) habitat (horizontal lines) within Washinton County, Idaho, generally illustrating their proximities to the Crane Creek KGRA. 


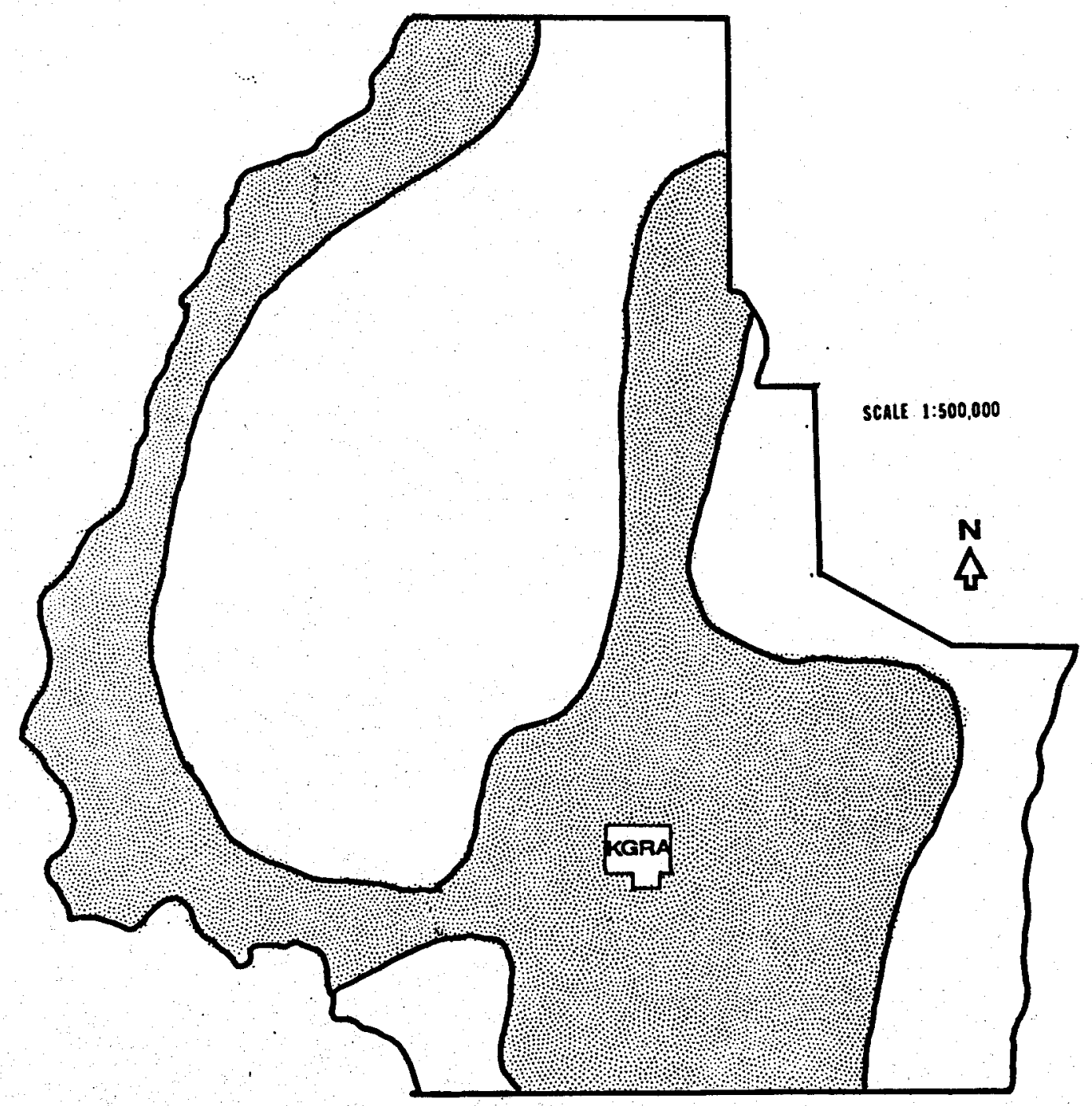

Figure 22. Distribution of Chukar (Alector is chukar) habitat within Washington County, Idaho, generally illustrating its proximity to the Crane Creek KGRA. 


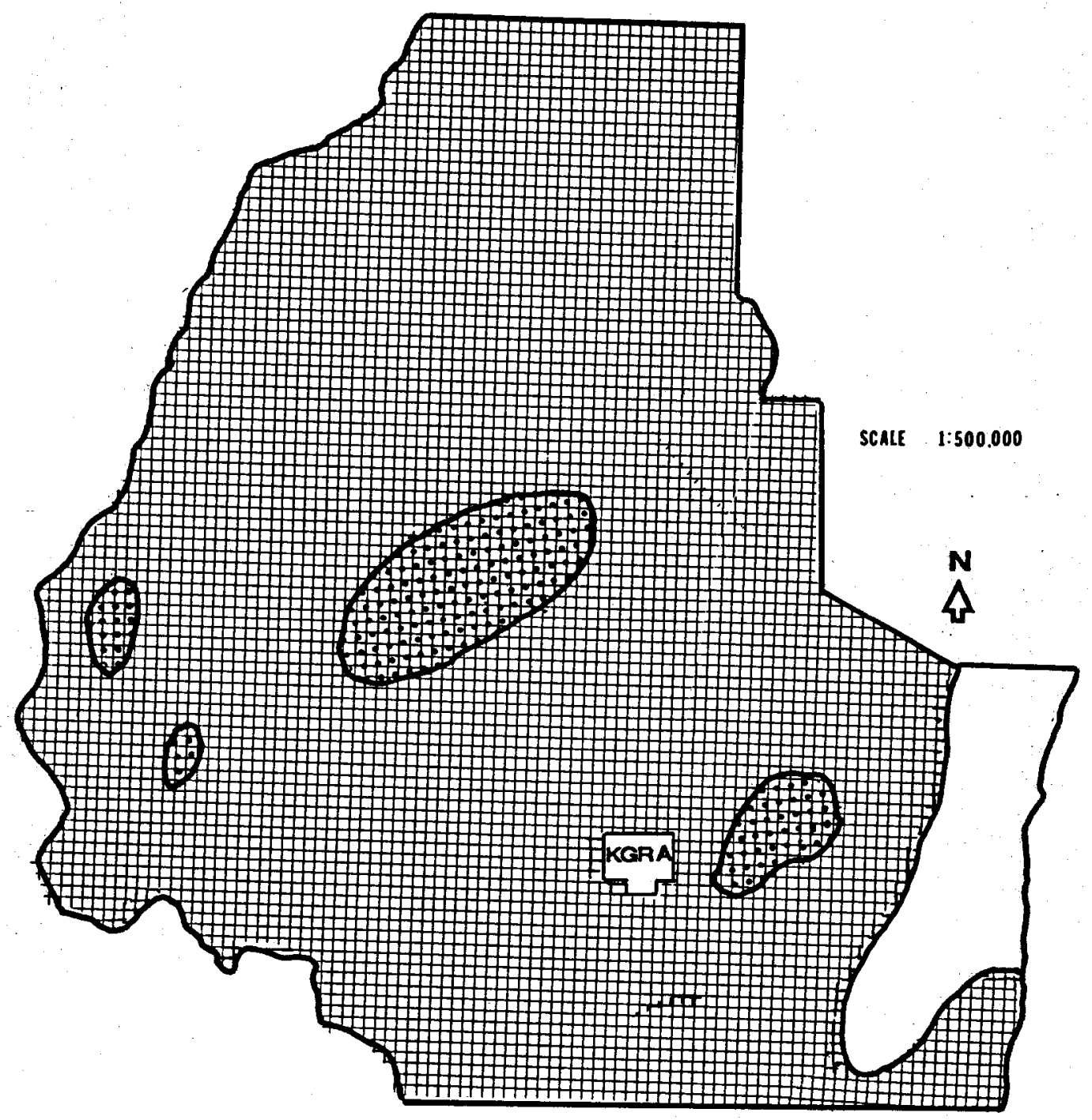

Figure 23. Distribution of Sage Grouse (Centrocercus urophasianus) habitat (cross-hatched) and its known strutting grounds (stippled) within Washington County, Idaho, generally illustrating the ir proximities to the Crane Creek KGRA. 


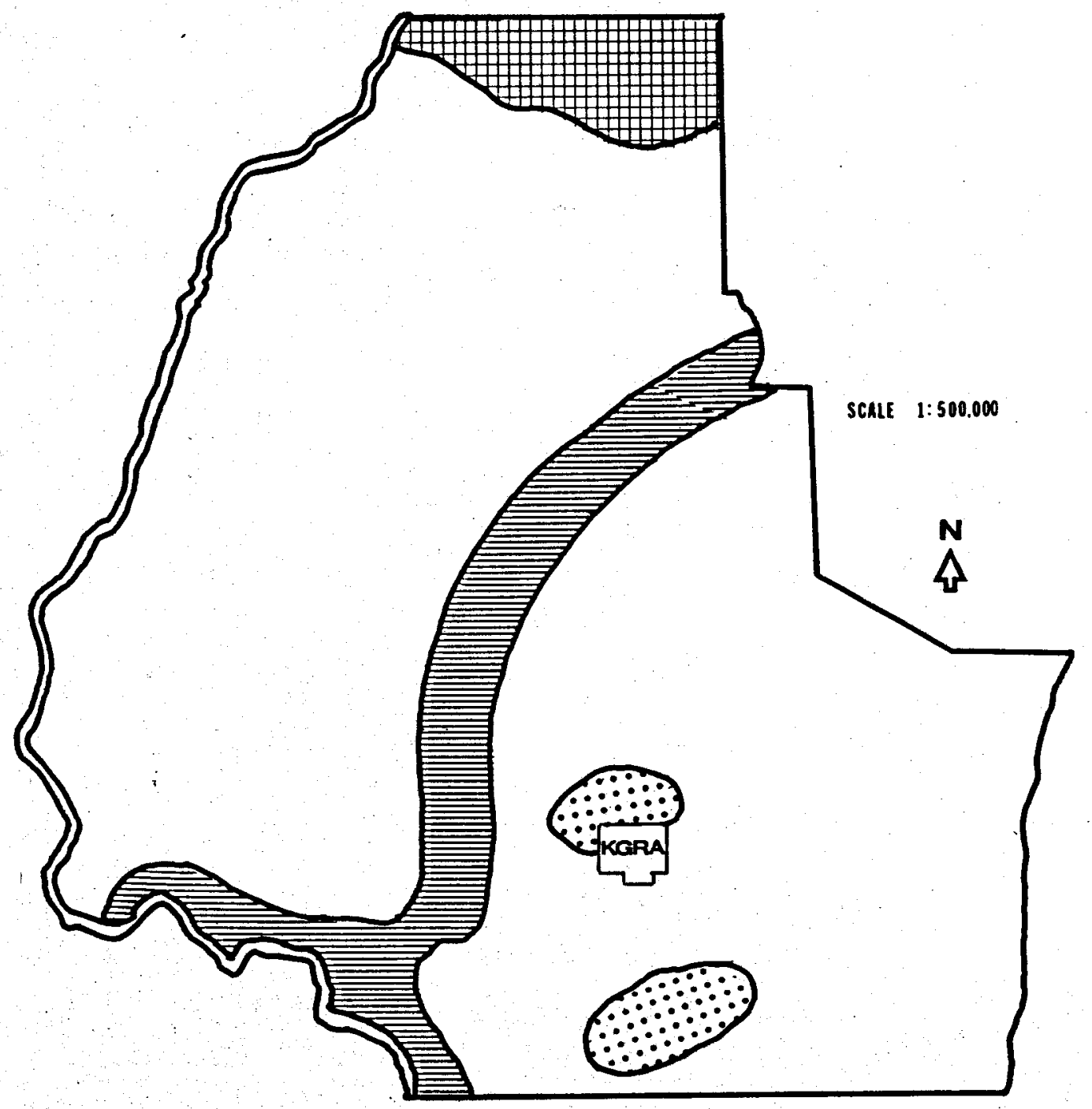

Figure 24. Distributions of Bald Eagle (Haliaectur leucocoephalus) wintering habitat (double lines), Wild Turkey (Meleagris gallopavo) habitat (cross-hatched) and waterfowl reproduction habitat (horizontal iines) within Washington County, Idaho. 


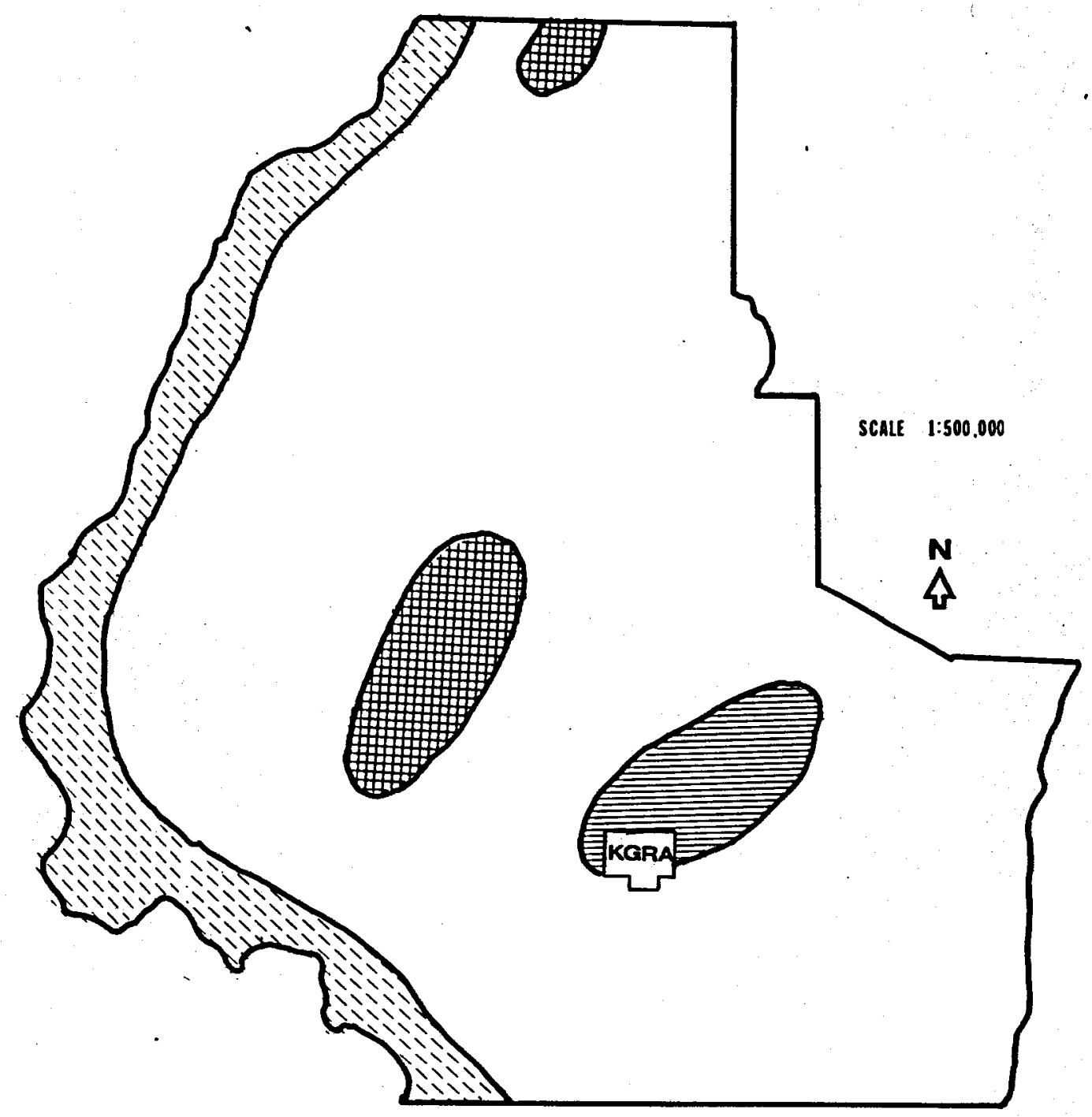

Figure 25. Distributions of White-faced Ibis (Plegadis chihi) habitat (horizontal lines), Sharp-tailed Grouse (Pedioecetes phasianellus) habitat (cross-hatched) and Prairie Falcon (Falco mexicanus) habitat (veritcal lines) within Washington County, Idaho, generally illustrating their proximities to the Crane Creek KGR.A. 


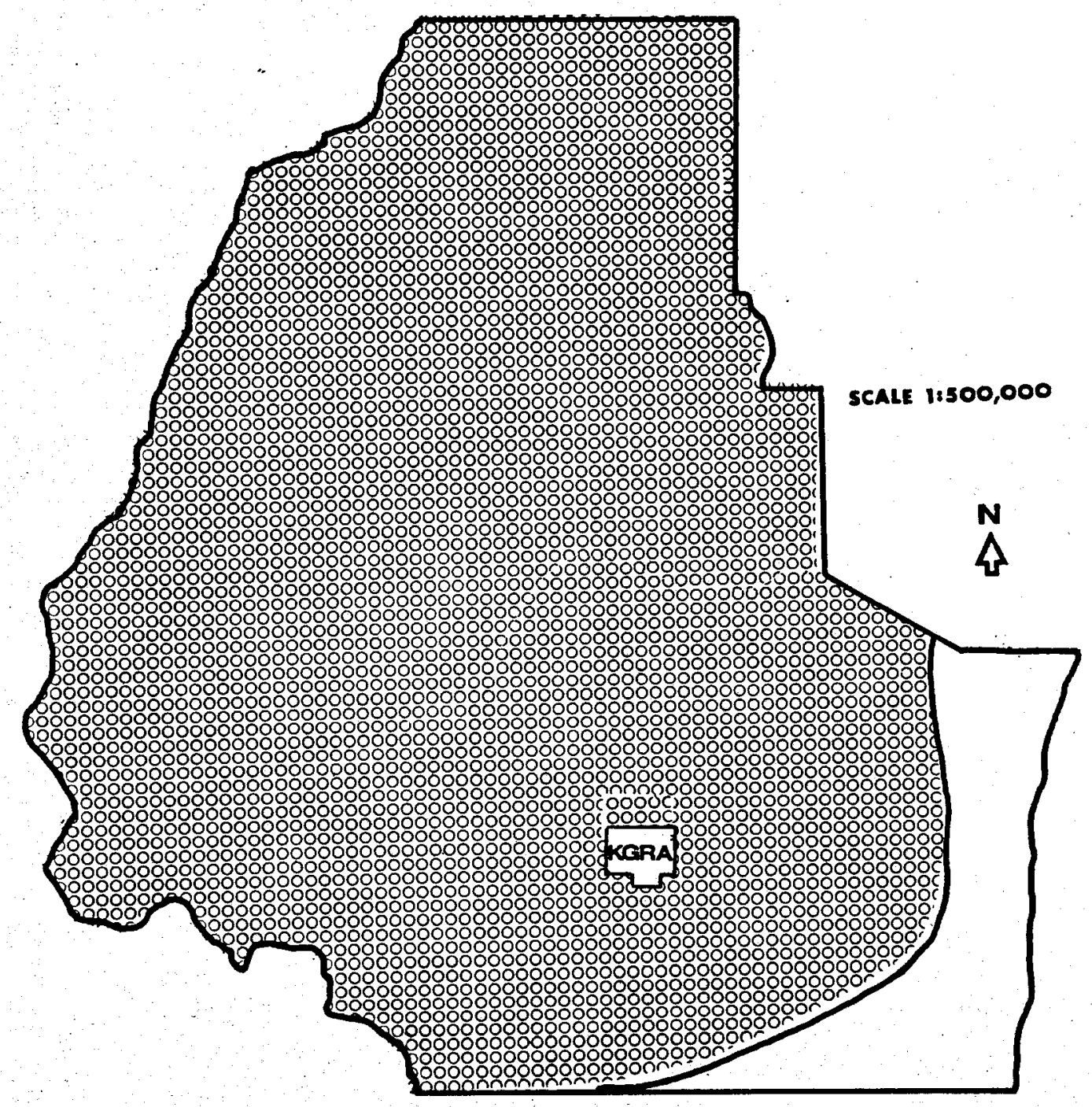

Figure 26. Distribution of Idaho Ground Squirrel (Spermophilus brunneus) within Washington County, Idaho, genera17y illustrating its proximity to the Crane Creek KGRA. 
Mule Deer use much of the KGRA as winter range (Figure 18). An assessment of this winter range, critical to deer herd maintenance, needs to be made to determine how big of an impact the development at the KGRA will have for Mule Deer wintering habitat.

The KGRA and most all of its non-competitive lease application area is included within Pronghorn habitat. Geothermal resource development should not interfere with Pronghorn growth and reproduction unless its presence interferes with migration to and from water.

A Sage Grouse strutting ground area is located near the KGRA. These strutting grounds are historically established and maintained year after year, and their preservation is essential to the reproductive success of the species. Eliminating or disturbing strutting grounds could have far reaching impacts on the population size, since birds do not of ten change to other strutting grounds. Additional work needs to be initiated to determine the location of the strutting grounds with respect to the KGRA, how many birds visit and breed at these grounds, what impact geothermal development will likely have on strutting success, what impact reduced strutting success at the grounds will have on the population, and the artificial establishment of new strutting grounds using captive-reared and released birds.

This KGRA has more migrating waterfowl flying over it than any of the other cold desert KGRAs (Table 13). This area does not serve as a resting area for migrating birds; therefore, no special attention to migrating waterfowl is required. Waterfowl reproduction occurs within the KGRA and these breeding areas need special consideration to insure their preservation.

The White-faced Ibis has breeding grounds included within the KGRA. No data delineating the number of Ibis present are available, and the uncertainty of this species creates a. problem of gathering data before geothermal development is in itiated. 
TABLE 13. ESTIMATED PERCENTAGE OF MIGRATING DUCKS, GEESE AND SWANS THAT FLY OVER THE KGRAS ANNUALLY

\begin{tabular}{|c|c|c|c|c|c|c|c|}
\hline \multirow[b]{2}{*}{ Specles } & \multicolumn{6}{|c|}{ Percent Over KGRA's } & \multirow{2}{*}{$\begin{array}{c}\text { Total Migrating } \\
\text { Birds } \\
\text { (thousands) }\end{array}$} \\
\hline & $\begin{array}{l}\text { Castle } \\
\text { Creek }\end{array}$ & Bru & ineau & $\begin{array}{c}\text { Mountain } \\
\text { Home }\end{array}$ & $\begin{array}{l}\text { Crane } \\
\text { Creek }\end{array}$ & Vulcan & \\
\hline Whistling Swan & - & & -- & - & -- & $\therefore$ & $102-233$ \\
\hline Lesser Snow Goose (Fa11) & $1-2$ & 1 & -2 & $1-2$ & $14-11$ & $14-11$ & $735-2,240$ \\
\hline Lesser Snow Goose (Spring) & $2-2$ & 2 & -2 & $2-2$ & $39-41$ & $39-41$ & $651-2,210$ \\
\hline Canada Goose (Small races) & $\therefore-$ & & $\therefore$ & - & - & - & $646-1,200$ \\
\hline Canada Goose (Large races) & $3-2$ & 3 & -2 & $3-2$ & $3-2$ & $3-2$ & $1,558-1,718$ \\
\hline American Wigeon & $17-16$ & 17 & -16 & $17-16$ & $17-16$ & $17-16$ & $2,419-4,950$ \\
\hline Gadwall & $3-2$ & 3 & -2 & $3-2$ & $3-2$ & $3-2$ & $778-3,010$ \\
\hline Green-W1nged Teal & - & & -- & - & $4-2$ & $4-2$ & $3,176-12,870$ \\
\hline Bluc-Winged Teal & $-\infty$ & & - & -- & $1-1$ & $1-1$ & $4,442-8,330$ \\
\hline Mallard & $12-11$ & 12 & -11 & $12-11$ & $12-11$ & $12-11$ & $12,078-26,850$ \\
\hline Pintail & - & & -- & -- & $23-20$ & $23-20$ & $8,520-17,500$ \\
\hline Shoveler & $3-4$ & 3 & -4 & $3-4$ & $9-9$ & $9-9$ & $1,116-2,560$ \\
\hline Canvasback & - & & - & - & - & - & $468-1,002$ \\
\hline Redhead & $5-6$ & 5 & -6 & $5-6$ & - & $5-6$ & $548-1,290$ \\
\hline Lesser Scaup & - & & - & -- & - & -- & $1,724-3,960$ \\
\hline Buff lehead & - & & -- & $-\infty$ & - & - & $240-$ \\
\hline Ruddy Duck & $13-13$ & 13 & -13 & - & - & $-\infty$ & $230-$ \\
\hline
\end{tabular}

a-Where a dash is entered in the table Implies that major flights over the KGRA are not expected, although the species is likely to be present in small, perhaps incidental numbers. 
An unresolved problem is the population and taxonomic status of the Idaho Ground Squirrel. The squirrel presumably has a wide range; but until the taxonomic status is made clear, its population and distribution data will remain questionable.

Aquatic Ecology (K. McCarthy, EG\&G Idaho)

Crane Creek is a major tributary of the Weiser River. The boundary of the KGRA is within $2 \mathrm{~km}$ of the confluence of the creek with the Weiser River. Aquatic data are available for the Weiser River Basin. The aquatic organisms discussed here represent the types present in the surrounding area that could be impacted by geothermal development and can be interpolated to exist within the boundaries of the study area.

Electroshocking surveys on the Weiser River conducted in 1974 and 1975 indicated 21 species of fish present. Figure 27 shows the percentage composition for total fish in the river. Benthic macroinvertebrates samples with a Surber sampler are shown in Table 14. Water depth at each sample site was less than $30.5 \mathrm{~cm} .{ }^{30}$

Aquatic macrophytes that reached "nuisance" levels in the Weiser River and adjacent sloughs and ponds were milfoil (Myriophyllum sp.), buttercup (Ranunculus reptans, Ranunculus trichophyllus, Callitriche heterophy11a), American pondweed (Potamogeton americanus), and coontail (Ceratophyllum demerson). All sites of abundant macrophytes were in areas with some disturbance such as irrigation or heavy grazing. The only sites of moving water nuisance levels were those containing the Potamogetons.

Total coliform bacteria counts at two stations below the crane Creek confluence on the Weiser River have revealed values of 3600 and 1250 immediate coliform per $100 \mathrm{ml}$, respectively. ${ }^{31}$ Standards set by the Environmental Protection Agency recommend a 1 count/100 ml maximum value for drinking water, while recommended values for secondary contact recreational use are 1000 counts $/ 100 \mathrm{ml} .^{32}$ 

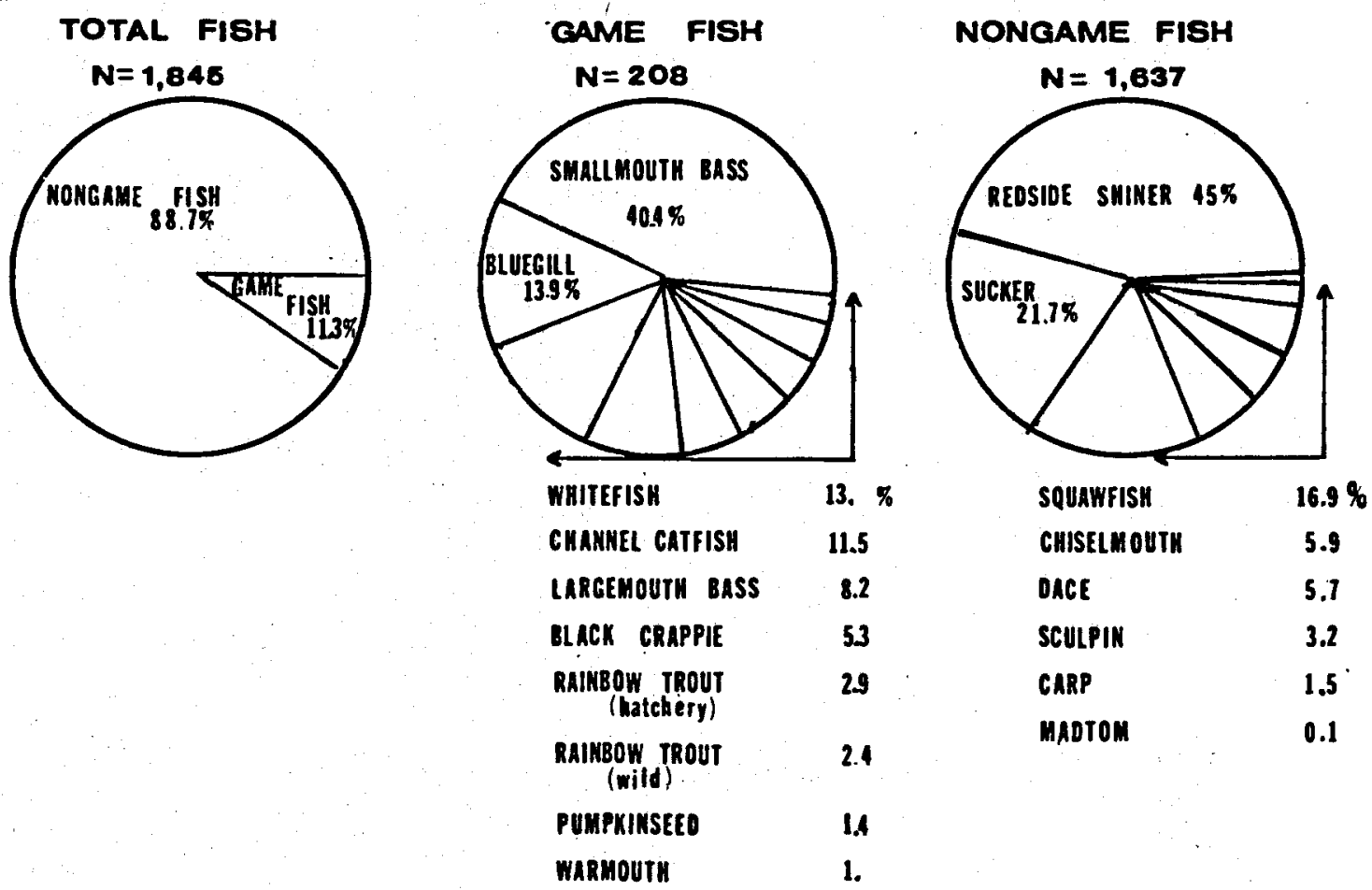

Figure 27. Percentage composition for total fish, game fish, and nongame fish in the electrofishing sample; Weiser River (Starkey downstream to the mouth at the Snake River), August 27 to September 10, 1974.30 
TABLE 14. WEISER RIVER BENTHOSa

\begin{tabular}{|c|c|c|c|c|}
\hline \multirow[b]{2}{*}{ Organism } & \multicolumn{4}{|c|}{ Location } \\
\hline & $\begin{array}{l}\text { Above } \\
\text { Weiser }\end{array}$ & $\begin{array}{c}\text { Below } \\
\text { Cambridge }\end{array}$ & Starkey & $\begin{array}{c}\text { Little Weiser } \\
\text { River } \\
\end{array}$ \\
\hline $\begin{array}{l}\text { Ephemeroptera (mayflies) } \\
\text { Baetidae } \\
\text { Heptagenidae } \\
\text { Ephemeridae }\end{array}$ & $\begin{array}{l}4.0 \\
7.8 \\
1.4\end{array}$ & $\begin{array}{l}16.0 \\
24.0\end{array}$ & $\begin{array}{r}2.8 \\
22.0 \\
0.4\end{array}$ & $\begin{array}{l}4.2 \\
1.3\end{array}$ \\
\hline $\begin{array}{l}\text { Trichoptera (cadd isflies) } \\
\text { Hydropsychidae } \\
\text { Limneph ilidae } \\
\text { Ryacophilidae } \\
\text { Brachycentridae }\end{array}$ & $\begin{array}{r}10.4 \\
15.0 \\
1.0\end{array}$ & $\begin{array}{r}145.8 \\
1.3 \\
0.2\end{array}$ & $\begin{array}{r}21.8 \\
45.6 \\
6.8\end{array}$ & 85.0 \\
\hline $\begin{array}{l}\text { Plecoptera (stoneflies) } \\
\text { Pteronarcidae } \\
\text { Perlidae }\end{array}$ & 1.6 & 2.4 & $\begin{array}{l}0.4 \\
2.6\end{array}$ & \\
\hline $\begin{array}{l}\text { Diptera } \\
\text { Chironomidae (midges) } \\
\text { Simulidae (blackflies) } \\
\text { Tipulidae } \\
\text { Rhagionidae } \\
\text { Tabanidae }\end{array}$ & $\begin{array}{r}32.2 \\
0.4\end{array}$ & $\begin{array}{l}6.6 \\
0.6 \\
0.4\end{array}$ & $\begin{array}{l}8.4 \\
1.2 \\
0.4 \\
0.2\end{array}$ & $\begin{array}{r}83.3 \\
2.0 \\
9.3\end{array}$ \\
\hline $\begin{array}{l}\text { Lepidoptera (moth) } \\
\text { Puralidae }\end{array}$ & & 3.8 & & \\
\hline $\begin{array}{l}\text { Coleoptera (Beet les) } \\
\text { Elmidae } \\
\text { Dytiscidae } \\
\text { Psephen idae }\end{array}$ & $\begin{array}{l}6.4 \\
0.2\end{array}$ & $\begin{array}{l}3.6 \\
2.6\end{array}$ & $\begin{array}{r}15.2 \\
0.2 \\
0.2\end{array}$ & $\begin{array}{r}15.0 \\
0.7\end{array}$ \\
\hline $\begin{array}{l}\text { Odonata } \\
\text { Gomphidae (dragonfly) } \\
\text { Coenagrionidae (damselfly) }\end{array}$ & & & & $\begin{array}{l}0.3 \\
0.3\end{array}$ \\
\hline $\begin{array}{l}\text { Mollusca } \\
\text { Nematoda (round worms) } \\
\text { Hirudinea (leeches) }\end{array}$ & $\begin{array}{r}0.6 \\
1.8 \\
12.4 \\
\end{array}$ & $\begin{array}{l}0.2 \\
0.2 \\
\end{array}$ & 0.6 & 2.3 \\
\hline $\begin{array}{l}\text { August number of insects/ } \\
\text { sample }\end{array}$ & 95.2 & 207.8 & 128.8 & 203.7 \\
\hline
\end{tabular}




\section{Human Environment}

The sections Demography, Socioeconomics, and Heritage Resources provide a detailed discussion of human environment of the Crane Creek KGRA.

Demography (C. Lewis, Lewis \& Associates)

The socioeconomic and demographic impacts of any significant geothermal resource development at the Crane Creek KGRA will be primarily in Washington County. Most of the socioeconomic data are reported on a county basis. In some cases, there may be a need for data for the area immediately surrounding the KGRA. In other cases, the county data will suffice.

Table 15 sumarizes population data for Washington County and the three principal population centers: Cambridge, Midvale, and Weiser. Between 1970 and 1976, population in the county grew 11.5\%. The components of population change, also reported in that table, show positive net migration of 500 . Population growth, especially when accompanied with net inmigration, is one indication of a healthy socioeconomic climate. Sumary characteristics of the population from the 1970 Census are reported in Table 16. Racially, it is a homogeneous population with Caucasians accounting for almost $98 \%$ of total population. The data on educational attainment and percentage of 16and 17-year-olds in school are about average.

Forecasts of population, employment by industry, labor force, and school enroliment are reported in Table 17. These data are current, having been developed in July 1978, and provide a more than adequate level of detail for environmental impact assessment. The projections are made through the year 2000 and provide a solid basis for the "no development" alternative. Such data are essential in an environmental 
TABLE 15. POPULATION CHANGE, 1970-1976 a AREA: WASHINGTON COUNTY

\begin{tabular}{lrrr}
\hline & \multicolumn{3}{c}{ Population } \\
\cline { 2 - 4 } County (Cities) & 1970 & $1976(1975)^{\mathrm{a}}$ & $\begin{array}{c}\% \text { Change } \\
1970-1976 \\
(1975)^{\mathrm{a}}\end{array}$ \\
\hline Washington County & 7,633 & 8,500 & 11.5 \\
(Cambridge) & 383 & 442 & 15.4 \\
(Midvale) & 176 & 409 & 132.4 \\
(Weiser) & 4,108 & 4,538 & 10.4 \\
\hline
\end{tabular}

Components of Population Change, 1970-1976

\begin{tabular}{lcrrr} 
Area & $\begin{array}{c}\text { Population } \\
\text { Change }\end{array}$ & Births & Deaths & $\begin{array}{c}\text { Net } \\
\text { Washington County }\end{array}$ \\
\cline { 1 - 3 } & 800 & 900 & 600 & 500 \\
\hline
\end{tabular}

${ }^{a}$ City data is for 1975 .

Source: U. S. Bureau of the Census, 1977. Idaho Department of Health and Welfare, 1977. Idaho Division of Budget, Policy P1anning, and Coordination, 1978. 
TABLE 16. SUMMARY CHARACTERISTICS OF THE POPULATION, 1970 AREA: WASHINGTON COUNTY

\begin{tabular}{|c|c|c|c|c|}
\hline \multicolumn{2}{|c|}{ Characteristics } & \multicolumn{2}{|l|}{ Number } & Percent \\
\hline \multirow[t]{3}{*}{ Population: } & White & 7,452 & & 97.6 \\
\hline & Black & 3 & & $\mathbf{a}$ \\
\hline & Other & 178 & & 2.3 \\
\hline & 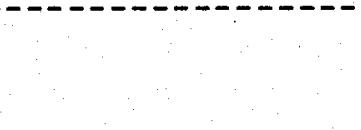 & ------- & $\frac{\text { Male }}{\%}$ & $\frac{\text { Female }}{\%}$ \\
\hline \multicolumn{3}{|c|}{ Median school years completed } & 10.9 & 12.0 \\
\hline \multicolumn{3}{|c|}{ Percent high school graduates } & 42.7 & 50.1 \\
\hline \multicolumn{3}{|c|}{ 16- 17 year-olds in school } & \multicolumn{2}{|c|}{86.0} \\
\hline \multicolumn{3}{|c|}{ Percent of population foreign born } & \multicolumn{2}{|c|}{2.7} \\
\hline
\end{tabular}

${ }^{a}$ Less than 0.05 percent.

Source: U. S. Bureau of the Census, 1972a. 


\section{TABLE 17. POPULATION AND EMPLOYMENT FORECAST, 1978, WASHINGTON COUNTY}

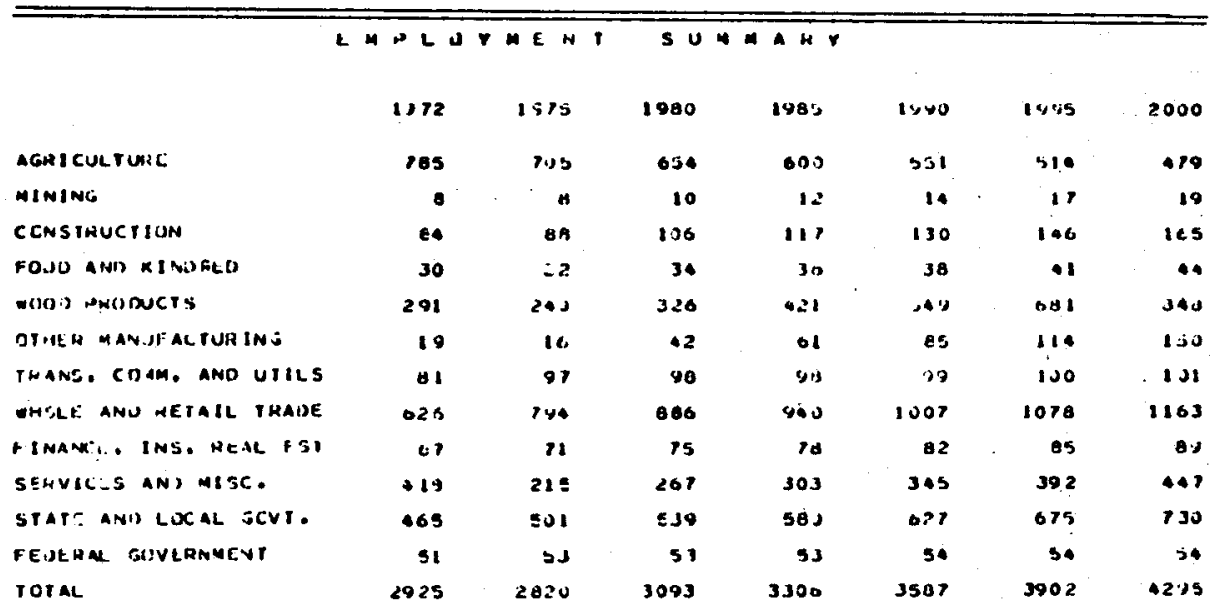

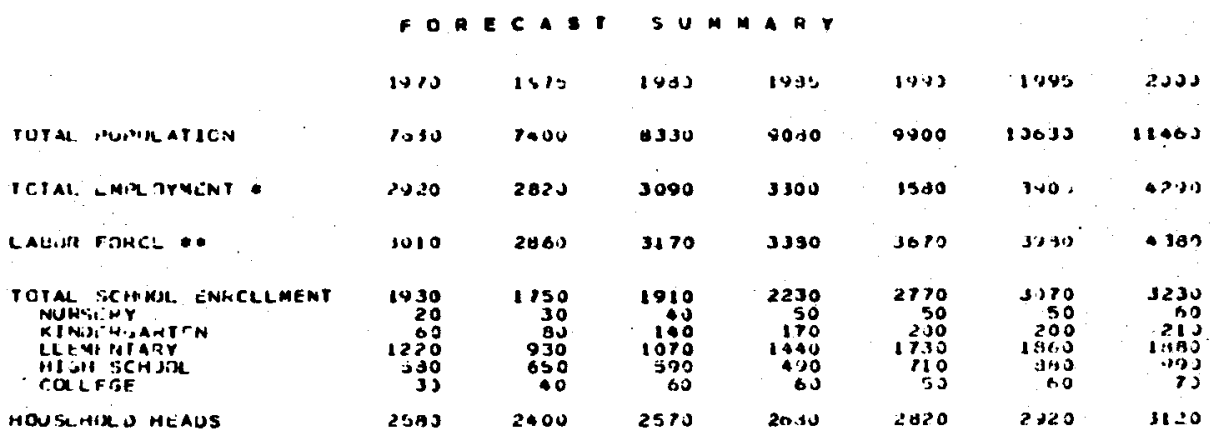

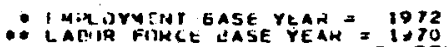

: LACIR FIJKE LASE YEAK

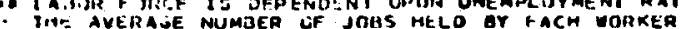

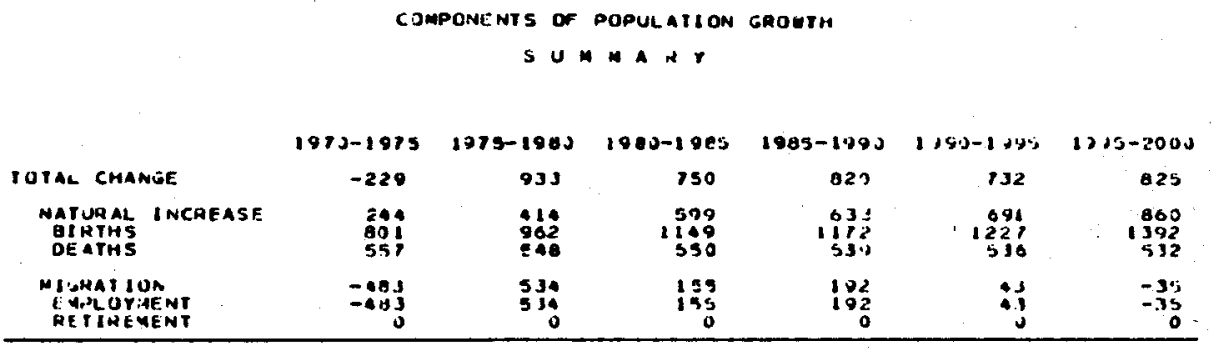

Source: Idaho Dept. of Water Resources and Center for Research, Grants, and Contracts, Boise State Univ., July, 1978. 
assessment to meet two objectives: (a) to describe the future socioeconomic environment in the absence of any significant resource development and (b) to provide a baseline or standard against which impacts of development can be compared. The projections show steady population and employment growth through the next 20 years. Projected net migration is positive until the period 1995 to 2000 .

Surmary data on school enroliment and number of teachers in the three school districts in Washington County are reported in Table 18. Weiser accounts for the largest share of total enroliment and reports a student/teacher ratio of 22.1, compared to $<15$ in the other two districts. The population impacts on the local school systems are expected to be concentrated in the Weiser and Midvale areas. The names, grades; and enrollment of all elementary, junior high, and senior high schools in those places are reported in Table 19.

Crime frequencies and rates per 100,000 population for the county are reported in Table 20 . These data are not surprising as they reflect conditions in most low-population areas in the intermountain west. The rather steady increase in the crime rate from 1971 through 1976 reflects a national trend. Since 1973, the rate of increase in the crime rate has been relatively low; and, as a general statement, crime does not appear to be anymore a problem here than in most places. For the Southwest Idaho region, only in Ada County, and especially in Boise, does the crime rate appear to be a serious problem.

The conventional wisdom in socioeconomic impact analysis suggests that rapid economic growth is almost always associated with a significant increase in crime rates. A review of several impacted communities suggests that the experience is varied. Some places have experienced what could be considered a crime epidemic. Other places have seen no measurable change. Given the magnitude and type of development expected in this KGRA, the crime rate is not expected to increase. 
TABLE 18. SUMMARY EDUCATION DATA AREA: WASHINGTON COUNTY

\begin{tabular}{|c|c|c|c|c|c|c|}
\hline \multirow[b]{2}{*}{ District } & \multicolumn{4}{|c|}{ Enro 11 ment } & \multirow[b]{2}{*}{ Teachers } & \multirow{2}{*}{$\begin{array}{c}\text { Student } \\
\text { Teacher } \\
\text { Ratio }\end{array}$} \\
\hline & Elementary ${ }^{a}$ & Secondary & Total & $\begin{array}{c}\text { Change From } \\
1976-1977\end{array}$ & & \\
\hline 431 - Weiser & 837 & 731 & 1,568 & +29 & 71 & 22.1 \\
\hline 432 - Cambridge & 118 & 143 & 261 & -6 & 18 & 14.5 \\
\hline 433 - Midvale & 66 & 92 & 158 & -15 & 14 & 11.3 \\
\hline Total & 1,021 & 966 & 1,987 & +8 & 103 & 19.3 \\
\hline
\end{tabular}

${ }_{\text {Grades }} \mathrm{K}-6$.

$\mathrm{b}_{\text {Grades }}$ 7-12.

Source: Idaho Department of Education, 1977 and 1978. 
TABLE 19. NAME, ENROLLMENT, AND LOCATION OF SCHOOLS NEAR KGRA, 1977-1978 AREA: CRANE CREEK KGRA (WASHINTON COUNTY)

\begin{tabular}{llll}
\hline City & School & Grades & Enrollment \\
\hline Weiser & Weiser Senior High Schoo1 & $9-12$ & 501 \\
Weiser & Weiser Junior High School & $7-8$ & 222 \\
Weiser & Park Intermediate School & $4-6$ & 349 \\
Weiser & Pioneer Primary School & K-6 & 472 \\
Midvale & Midvale Junior-Senior High School & $7-12$ & 141 \\
Midvale & Cambridge Elementary School & $1-6$ & 109 \\
\hline
\end{tabular}

Source: Fenne11, 1977. 
TABLE 20. CRIME FREQUENCIES AND RATES PER 100,000 POPULATION, 1971-1976 AREA: WASHINGTON COUNTY

\begin{tabular}{|c|c|c|c|c|c|c|}
\hline & 1971 & 1972 & 1973 & 1974 & 1975 & 1976 \\
\hline Part I Crimes (Rate) & $\begin{array}{c}182 \\
(2,213.3)\end{array}$ & $\begin{array}{c}191 \\
(2,329.3)\end{array}$ & $\begin{array}{c}246 \\
(2,925.8)\end{array}$ & $\begin{array}{c}246 \\
(2,952.8)\end{array}$ & $\begin{array}{c}254 \\
(2,978.4)\end{array}$ & $\begin{array}{c}259 \\
(2,986.3)\end{array}$ \\
\hline Murder & $\begin{array}{c}0 \\
(-)\end{array}$ & $\begin{array}{c}0 \\
(-)\end{array}$ & $\begin{array}{c}0 \\
(-)\end{array}$ & $\begin{array}{c}0 \\
(-)\end{array}$ & $\begin{array}{c}0 \\
(-)\end{array}$ & $\begin{array}{c}0 \\
(-)\end{array}$ \\
\hline Rape & $\begin{array}{c}0 \\
(-)\end{array}$ & $(12.2)$ & $\begin{array}{c}1 \\
(11.9)\end{array}$ & $\begin{array}{c}0 \\
(-)\end{array}$ & $\begin{array}{c}0 \\
(-)\end{array}$ & $\begin{array}{c}0 \\
(-)\end{array}$ \\
\hline Robbery & $\begin{array}{c}0 \\
(-)\end{array}$ & $\begin{array}{c}1 \\
(12.2)\end{array}$ & $\begin{array}{c}0 \\
(-)\end{array}$ & $\begin{array}{c}3 \\
(36.0)\end{array}$ & $\begin{array}{c}3 \\
(35.2)\end{array}$ & $\begin{array}{c}3 \\
(34.6)\end{array}$ \\
\hline Aggravated assault & $\begin{array}{c}0 \\
(-)\end{array}$ & $\begin{array}{c}3 \\
(36.6)\end{array}$ & $\begin{array}{c}8 \\
(95.1)\end{array}$ & $\begin{array}{c}9 \\
(108.0)\end{array}$ & $\begin{array}{c}6 \\
(70.4)\end{array}$ & $\begin{array}{c}10 \\
(115.3)\end{array}$ \\
\hline Burglary & $\begin{array}{c}18 \\
(218.9)\end{array}$ & $\begin{array}{c}28 \\
(341.5)\end{array}$ & $\begin{array}{c}41 \\
(487.6)\end{array}$ & $\begin{array}{c}49 \\
(588.2)\end{array}$ & $\begin{array}{c}43 \\
(504.2)\end{array}$ & $\begin{array}{c}52 \\
(599.6)\end{array}$ \\
\hline Larceny & $\begin{array}{c}156 \\
(1,897.1)\end{array}$ & $\begin{array}{c}155 \\
(1,890.2)\end{array}$ & $\begin{array}{c}189 \\
(2,247.9)\end{array}$ & $\begin{array}{c}179 \\
(2,148.6)\end{array}$ & $\begin{array}{c}191 \\
(2,239.7)\end{array}$ & $\begin{array}{c}185 \\
(2,133.1)\end{array}$ \\
\hline Motor vehicle theft & $\begin{array}{c}8 \\
(97.3)\end{array}$ & $\frac{3}{(36.6)}$ & $\begin{array}{c}7 \\
(83.3)\end{array}$ & $\begin{array}{c}6 \\
(72.0)\end{array}$ & $\begin{array}{c}11 \\
(129.0)\end{array}$ & $\begin{array}{c}9 \\
(103.8)\end{array}$ \\
\hline
\end{tabular}

Source: Idaho Law Enforcement Planning Commission, 1978. 
Health care capability is another area for concern since many low-population areas provide only limited medical facilities and personnel. Washington County has only four doctors, implying a population per physician ratio of 2100 , and one hospital with 30 acute care beds. Ambulance services are available. Any significant economic growth, regardless of the source, may strain the ability of the county health care resources to service an expanded population.

In general, the demographic data must be regarded as at least adequate for environmental studies. The population data, both for the county and for principal population centers, are relatively current. The data on characteristics of the population are outdated, having been collected in 1970, but probably are not of sufficient importance to warrant spending additional resources to provide an updated data set.

The projections of population, labor force, and employment must be regarded as excellent. They are current and provide the type of details that are needed for environmental studies.

Additional data in the education and health care areas would be useful. Especially important would be capacity data for schools in the area. Enrollment and number of teachers have been reported; but capacity data are not available from secondary sources. Some idea of. the location and ability of the four physicians in the county to service the population would be of value.

Socioeconomics (C. Lewis, Lewis \& Associates)

Sumary data on labor force, unemployment, and employment in Washington County for the period 1974 through 1977 are reported in Table 21. 
TABLE 21. LABOR FORCE, UNEMPLOYMENT, UNEMPLOYMENT RATE, AND EMPLOYMENT, 1974-1977 AREA: WASHINGTON COUNTY

\begin{tabular}{llccc}
\hline \hline Year & $\begin{array}{l}\text { Labor } \\
\text { Force }\end{array}$ & Unemployment & $\begin{array}{c}\text { Unemployment } \\
\text { Rate }\end{array}$ & Employment \\
\hline 1974 & 3,309 & 272 & 8.2 & 3,037 \\
1975 & 3,222 & 339 & 10.5 & 2,883 \\
1976 & 3,338 & 288 & 8.6 & 3,050 \\
1977 & 3,514 & 290 & 8.3 & 3,224 \\
\hline
\end{tabular}

Source: Idaho Department of Employment Security, 1977, 1978a, and 1978b. 
The unemployment rate has consistently been in excess of $8 \%$, suggesting a lack of strength in the employment market. For 1977, an average 290 workers were unemployed, indicating the labor pool is available to a potential new industrial development. Some of that employment is seasonal and does not reflect the availability of workers to move into other industry. However, development requiring an additional 100 to 200 workers would not strain the ability of the local labor market to meet the demand.

Detailed employment data for 1971 through 1976 are reported in Table 22, and an analysis of the employment data is included in Table 23. Of particular interest are the location quotients, which indicate the relative specialization of industry compared to both the nation and the state. A location quotient in excess of unity implies the county has more than a proportionate share of employment in that sector. Relative to the nation, agriculture, wholesale trade, and state and local government are the relatively important sectors. While employment growth has not been great, it has been steady. Since 1971, there has been only one year where total employment declined (1975).

The ability of the local economy to supply residents with goods and services is an area of concern. Summary data on retail trade and se lected services activity for 1972 are reported in Tables 24 and 25. Data are shown for Washington County, Weiser, and the rest of county area. Most of the retail and virtually all of the services activity are concentrated in Weiser, with only limited numbers of establishments outside the city.

Detailed data on personal income by major source and a set of sumary analytics are reported in Tables 26 and 27 . These data are provided from the Regional Economics Information Sys̄tem developed and managed by the Bureau of Economic Analysis of the U.S. Department of Commerce (1978). 
TABLE 22. EMPLOYMENT BY TYPE AND BROAD INDUSTRIAL SOURCES, 1971-1976

(FULL- AND PART-TIME), WASHINGTON COUNTY

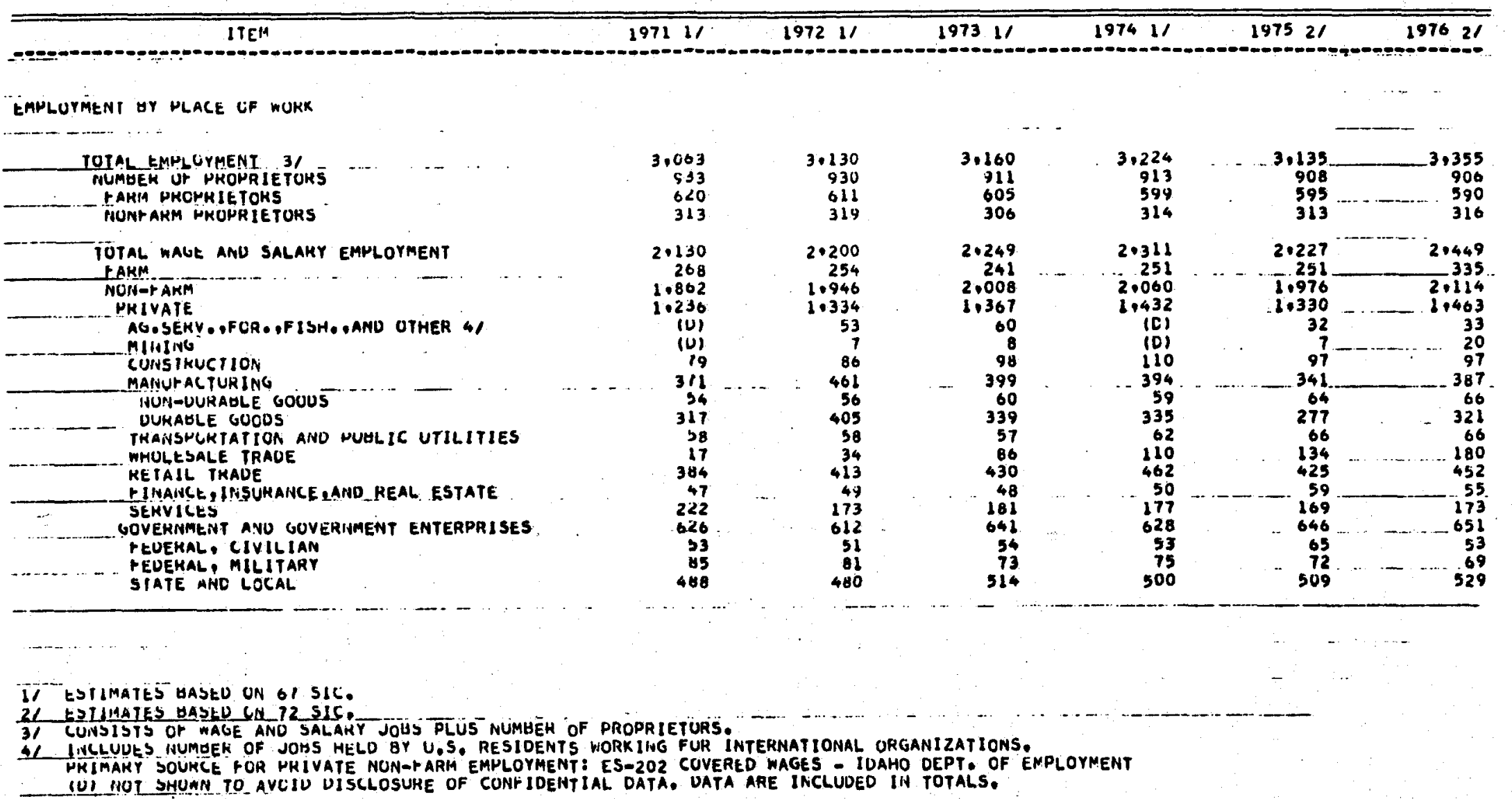

Source: Regional Economics Information System, Bureall of Economic Analysis, August, 1978. 
TABLE 23. EMPLOYMENT BY TYPE AND BROAD INDUSTRIAL SOURCES, 1971-1976 (FULL- AND PARTTIME -- SUMMARY ANALYTICS), WASHINGTON COUNTY

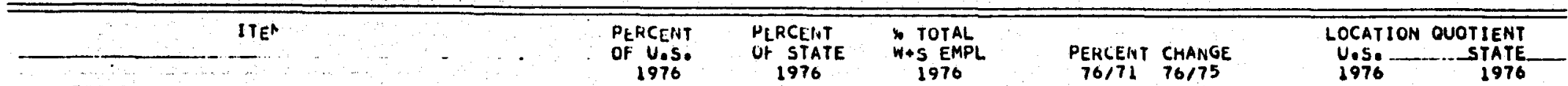

EMPLUTMENT OY PLACE OF WUKK

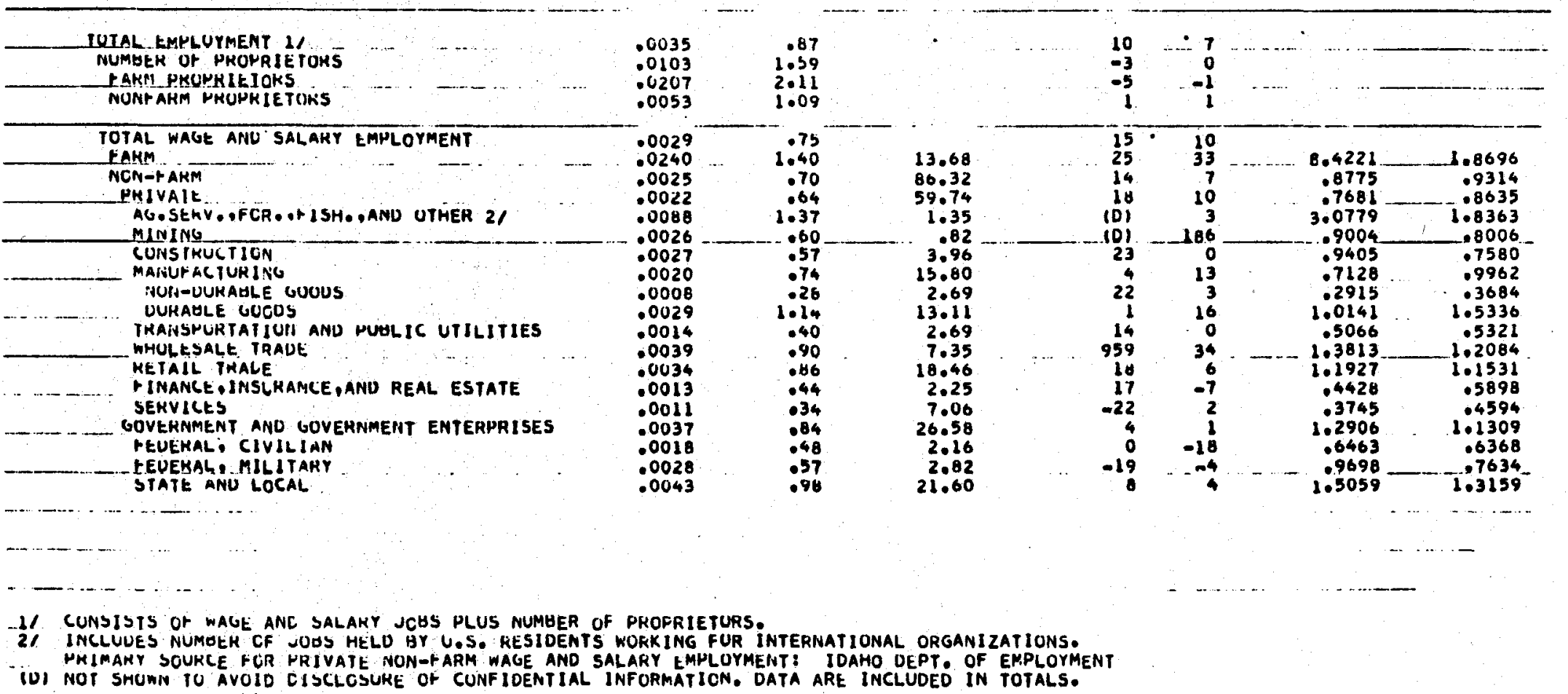

Source: Regional Economics Information System, Bureau of Economic Analysis, August, 1978. 
TABLE 24. SUMMARY SELECTED SERVICES DATA, 1972 AREA: WASHINGTON COUNTY

\begin{tabular}{|c|c|c|c|c|c|c|}
\hline & & & $\begin{array}{r}\text { Washing } \\
\text { Count }\end{array}$ & \multicolumn{2}{|r|}{ Weiser } & $\begin{array}{l}\text { Rest of } \\
\text { County }\end{array}$ \\
\hline Al1 establishments: $\begin{array}{l}\text { Number } \\
\text { Receipts }\end{array}$ & $(000)$ & & \multicolumn{2}{|c|}{$\begin{array}{r}78 \\
\$ 1,313\end{array}$} & $\begin{array}{r}63 \\
\$ 1,098\end{array}$ & $\begin{array}{r}15 \\
\$ 215\end{array}$ \\
\hline Establishments with payro11: & $\begin{array}{l}\text { Number } \\
\text { Rece ip } \\
\text { Payrol } \\
\text { Employ }\end{array}$ & $\begin{array}{l}(000) \\
000)\end{array}$ & \multicolumn{2}{|c|}{$\begin{array}{r}27 \\
847 \\
153 \\
58\end{array}$} & $\begin{array}{l}24 \\
\text { (D) } \\
\text { (D) } \\
\text { (D) }\end{array}$ & $\begin{array}{l}3 \\
\text { (D) } \\
\text { (D) } \\
\text { (D) }\end{array}$ \\
\hline - & Washin & County & \multicolumn{2}{|c|}{ Weiser } & \multicolumn{2}{|c|}{ Rest of County } \\
\hline Service & Number & Receipts & Number & Receipts & Number & Receipts \\
\hline Hotels, mote1s, etc. & 3 & $\$ 118$ & 3 & $\$ 118$ & -- & -- \\
\hline Automotive repair & 12 & 249 & 8 & 166 & 4 & $\$ 83$ \\
\hline Misce 11 aneous repair & 11 & 181 & 10 & (D) & 1 & (D) \\
\hline Amusement and recreation & 12 & 149 & 8 & (D) & 4 & (D) \\
\hline Legal services & 6 & 168 & 6 & 168 & -- & -- \\
\hline
\end{tabular}

(D) -- not reported to avoid disclosure of individual firm data.

Source: U. S. Department of Commerce, $1976 \mathrm{f}$. 
TABLE 25. SUMMARY RETAIL TRADE DATA, 1972 AREA: WASHINGTON COUNTY

\begin{tabular}{|c|c|c|c|}
\hline & $\begin{array}{l}\text { Washington } \\
\text { County }\end{array}$ & Weiser & $\begin{array}{l}\text { Rest of } \\
\text { County }\end{array}$ \\
\hline $\begin{aligned} \text { All establishments: } & \text { Number } \\
& \text { Sales }(000)\end{aligned}$ & $\begin{array}{r}119 \\
\$ 14,086\end{array}$ & $\begin{array}{r}82 \\
\$ 12,361\end{array}$ & $\begin{array}{r}37 \\
\$ 1,725\end{array}$ \\
\hline $\begin{aligned} \text { Establishments with payroll: } & \text { Number } \\
& \text { Sales (000) } \\
& \text { Payrol1 (000) } \\
& \text { Employees }\end{aligned}$ & $\begin{array}{r}74 \\
\$ 12,999 \\
1,359 \\
313\end{array}$ & $\begin{array}{r}57 \\
\$ 11,649 \\
1,215 \\
257\end{array}$ & $\begin{array}{r}17 \\
\$ 1,350 \\
144 \\
56\end{array}$ \\
\hline \multicolumn{4}{|l|}{ Number of establishments: } \\
\hline $\begin{array}{l}\text { Building materials, hardware, etc. } \\
\text { General merchandise } \\
\text { Food stores } \\
\text { Automotive dealers } \\
\text { Service stations } \\
\text { Apparel and accessory stores } \\
\text { Furniture and home furnishings } \\
\text { Eating and drinking places } \\
\text { Drug stores } \\
\text { Miscellaneous }\end{array}$ & $\begin{array}{r}5 \\
3 \\
15 \\
10 \\
13 \\
5 \\
5 \\
30 \\
4 \\
29\end{array}$ & $\begin{array}{r}4 \\
2 \\
10 \\
9 \\
9 \\
5 \\
3 \\
16 \\
3 \\
21\end{array}$ & $\begin{array}{r}1 \\
1 \\
5 \\
1 \\
4 \\
-- \\
2 \\
14 \\
1 \\
8\end{array}$ \\
\hline
\end{tabular}

Source: U. S. Department of Commerce, $1976 \mathrm{c}$. 
TABLE 26. PERSONAL INCOME BY MAJOR SOURCES, 1971-1976 (Thousands of Dollars), WASHINGTON COUNTY

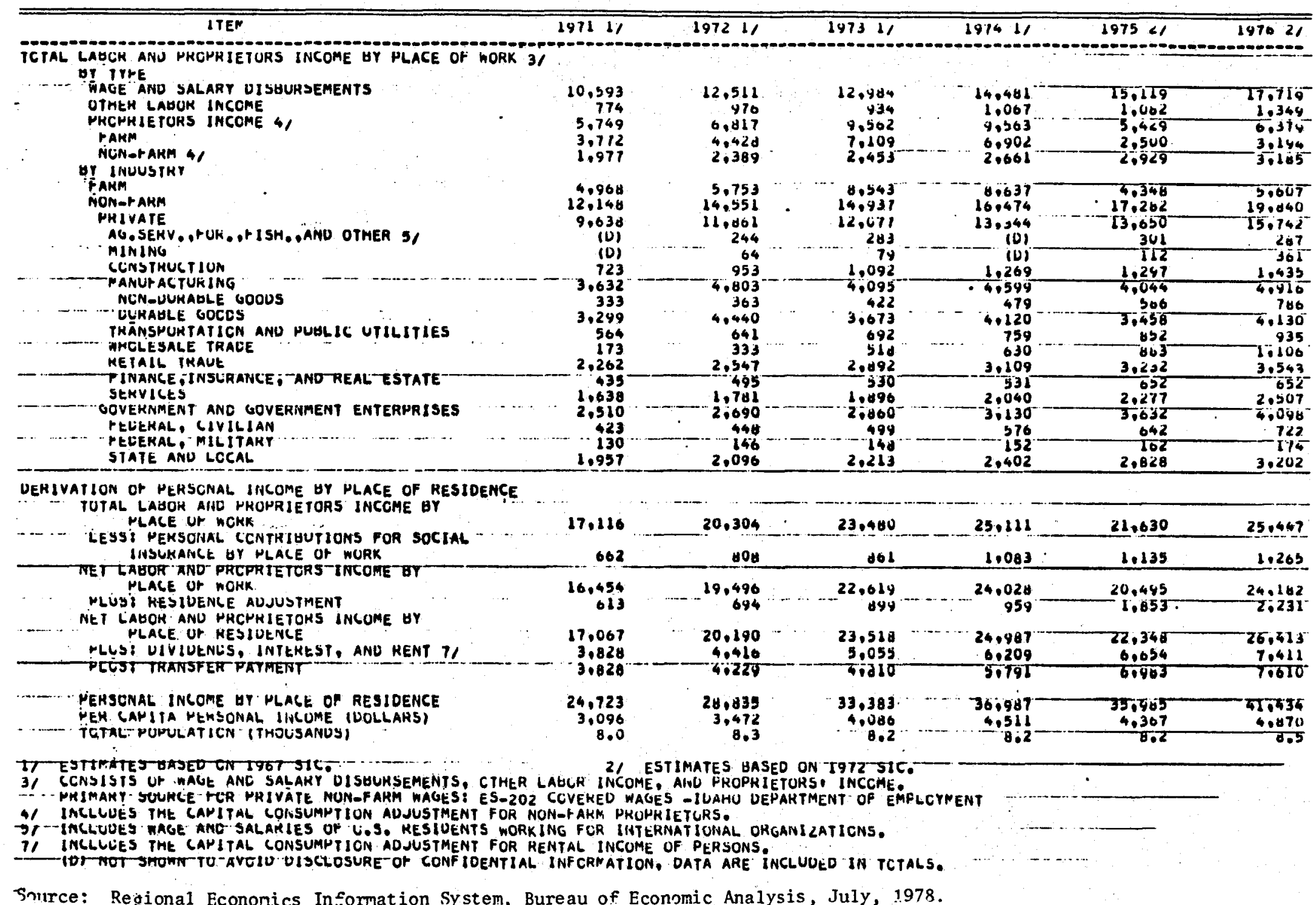


TABLE 27. PERSONAL INCOME BY MAJOR SOURCES, 1971-1976 (SUMMARY ANALYTICS), WASHINGTON COUNTY

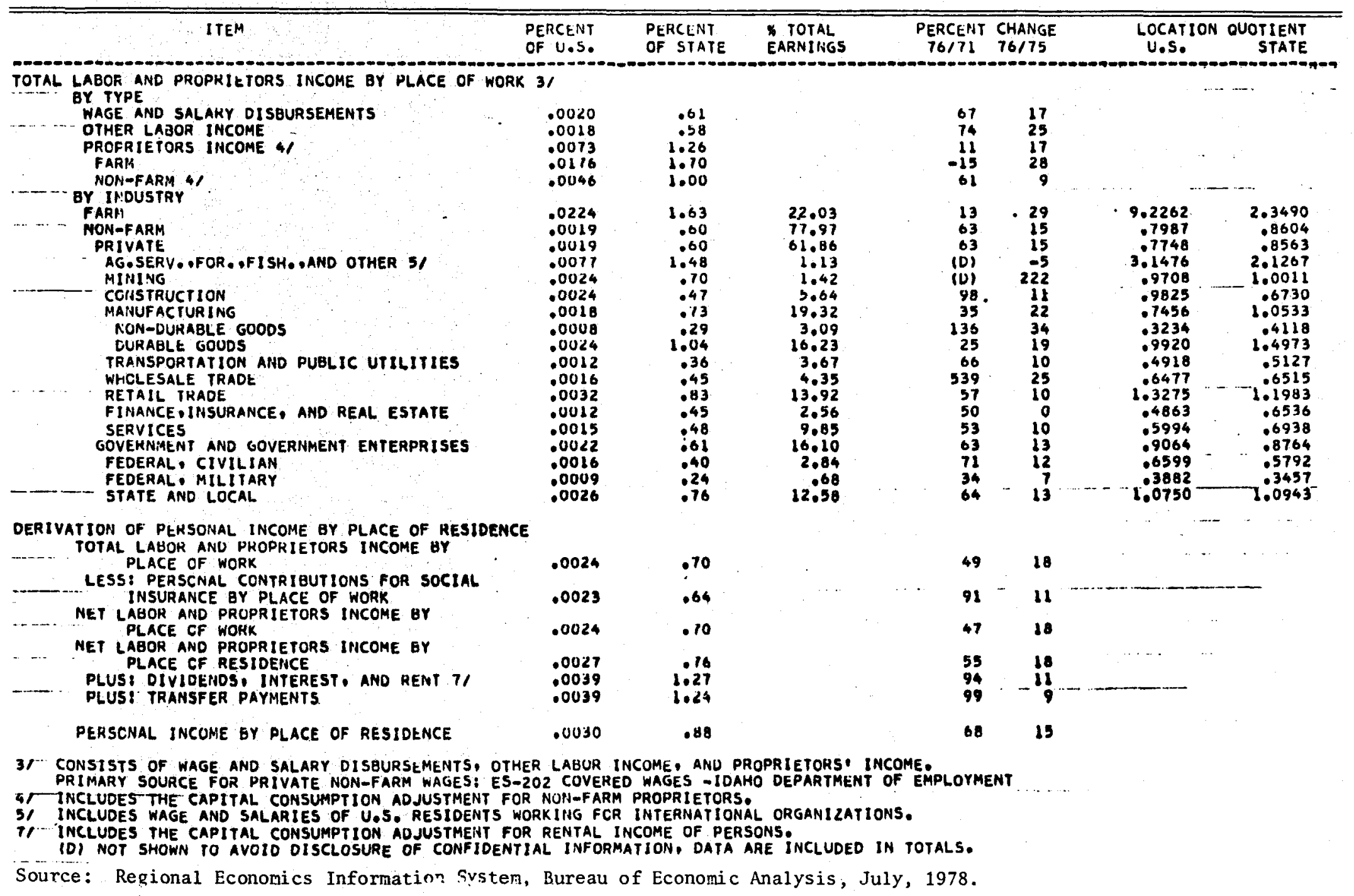


Data on agriculture are especially important because that sector may be significantly impacted by geothermal resource development. Sumary agricultural data from the 1974 Census of Agriculture are reported in Table 28. Agriculture is especially important in Washington County, accounting for about $22 \%$ of total industrial earnings in industry. Average farm size is in excess of $400 \mathrm{ha}$, and more than one half of the county land area is in farms. Irrigated agriculture is relatively unimportant in size, as it accounts for only $6.6 \%$ of all farmland; but because geothermal development may impact on the quantity and quality of water available from wells, this area can be especially important.

Related to the agricultural question is the whole area of land use; data are reported in Table 29. As shown, urban use accounts for less than $1 \%$ of total land area, with agricultural and rangeland accounting for almost $80 \%$, and $55.9 \%$ of county land area is privatelyowned. This is quite different than many parts of the intermountain west where the federal government owns the majority of the land area.

A summary of the availability of land-use control mechanisms is also reported in Table 29. Washington County has a planning and zoning commission and subdivision ordinance but has no county comprehensive $\mathrm{plan}$ or zoning ordinance at this time.

Surmary data on assessed value and property tax charges for 1977 are reported in Table 30. Assessed value of property in the county per capita is $\$ 3,131$, with property tax charges averaging $\$ 148$. On real and personal property on $1 y$, per capita taxes are $\$ 166$. Selected measures of uniformity in assessment ratios are also provided in Table 30. The relatively large coefficient of variation suggests some disparity in assessment ratios among properties and the possible existence of some equity problems in property taxation. 
TABLE 28. GENERAL AGRICULTURAL DATA, 1974 AREA: WASHINGTON COUNTY

\begin{tabular}{lr}
\hline Number of farms & 503 \\
Land in farms (acres) & 518,735 \\
Average farm size (acres) & 1,031 \\
County land area (acres) & 935,936 \\
Percent in farms & $55.4 \%$ \\
Value of land and buildings & \\
Total (000) & $\$ 75,603$ \\
Per farm & $\$ 150,304$ \\
Per acre & $\$ 146$ \\
Cropland (acres) & 101,591 \\
Percent of al1 land & $10.9 \%$ \\
Percent of all farmland & $19.6 \%$ \\
Irrigated land (acres) & 34,275 \\
Percent of all land & $3.7 \%$ \\
Percent of all farml and & $6.6 \%$ \\
Quantity of irrigation water applied (ac ft) & 90,356 \\
Per acre (ac ft) & 2.7 \\
Value of agricultural products sold--total (ooo) & $\$ 16,924$ \\
Average per farm & $\$ 33,647$ \\
\hline
\end{tabular}

Source: U. S. Bureau of the Census, 1977. 
TABLE 29: SUMMARY DATA ON LAND USE, LAND OWNERSHIP, AND LAND-USE CONTROL MECHANISMS, 1976-1977

AREA: WASHINGTON COUNTY

\begin{tabular}{lcc}
\hline & Acres & $\%$ of Total \\
\hline Land Use--1976: & & \\
Urban & 3,500 & 0.4 \\
Agricultural & 134,000 & 13.8 \\
Rangeland & 706,100 & 74.6 \\
Other & 104,900 & 11.2 \\
Land Ownership--1977: & & 37.0 \\
Federal government & 345,946 & 6.8 \\
State government & 63,254 & 55.9 \\
Private & 523,621 & 0.3 \\
Local government & 3,115 & \\
Land-Use Control Mechanisms: & & \\
Planning and Zoning Commission & Yes & \\
County Comprehensive Plan & No & \\
Subdivision Ordinance & Yes & \\
Zoning Ordinance & No & \\
\hline
\end{tabular}

Source: Idaho Division of Budget, Policy Planning, and Coordination, 1978 


\section{TABLE 30. SUMMARY DATA ON ASSESSED VALUE AND PROPERTY \\ TAX CHARGES, 1977 \\ AREA: WASHINGTON COUNTY}

\begin{tabular}{lr}
\hline Assessed value of all property--total (000) & $\$ 26,610$ \\
$\quad$ Per capita & $\$ 3,131$ \\
All property tax charges--total (000) & $\$ 2,261$ \\
Per capita & $\$ 266$ \\
Property tax charges-real and personal property-- & \\
$\quad$ total (000) & $\$ 1,408$ \\
Per capita & $\$ 166$ \\
Measures of uniformity in assessment ratios: & 14.76 \\
Weighted assessment ratio & 0.97 \\
Regression index & 36.21 \\
Coefficient of variation & \\
\hline
\end{tabular}

Source: Idaho State Tax Commission, 1977a. 
With few exceptions, the socioeconomic data are more than adequate for environmental assessment studies. The housing data are an exception.

The 1970 data may provide a guide for additional data collection but are of no value in assessing quality, availability, or cost of housing. The land-use data do not provide details for land use in the immediate vicinity of the KGRA, nor the agricultural sector in that immediate vicinity. The retail trade and selected services data are six years old and are somewhat outdated. The private sector is expected to provide goods and services when the demand exists; and it is not clear if there is much of a role to be played by the public sector through the planning process.

Heritage Resources (R. Knudson, M. Pfaff, Idaho Water Resources Research Institute)

Paleontological Resources. In the Weiser area ${ }^{33}$ Upper Miocene floral remains have been found in the Payette Formation, a set of sedimentary interbeds of white tuffaceous sand that are intercolated between members of the Miocene plateau basalts. This later Tertiary vegetation is unique within the plateau. These Payette flora have not been specifically identified within the Crane Creek KGRA, but the Tertiary vegetation is within the general area of the florally rich Payette Formation. Bond and others ${ }^{34}$ map the border between the Miocene igneous extrusive basalts and the contemporary sedimentary. formations across the KGRA. Paleontological field reconnaissance of this area is needed before further plans can be developed.

Prehistoric Resources. There has been no professional archaeological reconnaissance conducted within the Crane Creek KGRA to date. Surveys within the general Weiser River valley within the last three decades include an early reconnaissance of selected proposed reservoir areas by the Columbia River Project, River Basin Surveys, Smithsonian Institution in the late $1940 \mathrm{~s}^{35}$, and of proposed highway projects by 
Idaho State University in the early $1960 \mathrm{~s}^{36,37}$. In 1964 to 1965, Alfred Bowers of the University of Idaho conducted extensive surveys across Washington County as well as test excavations in the area of Mann Creek Reservoir west of the Crane Creek KGRA. ${ }^{35}$ Further excavations and analysis of the Midvale Complex ${ }^{36,37,38}$, of the Mesa Hill site ${ }^{39}$, and within Hells Canyon $40,41,42$ to the north and northwest of the Crane Creek provide a framework for evaluation of the potential prehistoric archaeological resources for the Crane creek KGRA.

Bowers $^{35}$ report of his reconnaissance of Washington County is brief, with terse site reports that essentially provide site locational data. He does record the recovery of a mid-section of a folsom projectile point at a mapped location near Ant Butte, California, 10 $\mathrm{km}$ east of the Crane Creek KGRA and just south of the Crane Creek Reservoir. 35 Folsom points in eastern Idaho are found in archaeological contexts that are dated at approximately 10,900 years ago. 43 The Ant Butte isolated find does not constitute a significant archaeological site and could have been dropped in the area by later inhabitants; the point is an indication that considerable time depth could be expected of the cultural resources in the Crane Creek area.

Bowers had little way of establishing good temporal controls on the materials he found during his 1964 and 1965 surveys in Washington County, though he did note considerable artifactual variation among the assemblages of his 116 recorded sites. He did test excavate one site within the proposed Mann Creek Reservoir take-line, the Spangler site $(10-W N-30)$, and was able to date a significant cultural component there at 600 years ago ${ }^{35}$ with additional cultural materials in place well below the dated level. The Spangler site and three other prehistoric sites near it are located in a topographic setting very 
similar to that of the Crane Creek KGRA -- and alluvial valley that is tributary to the main Weiser River valley, near the valley wall created by erosion of the Miocene basalts, in the vicinity of good springs and a permanent stream. Thus, materials similar to those at Spangler could be remnant in the Crane Creek area.

Bowers also noted the presence of an unusual set of artifacts spread across Washington County, ${ }^{35}$ we 11 -made bifaces and flake tools of fine-grained basalt. These materials had first been noted in the Midvale area about $15 \mathrm{~km}$ up the Weiser Valley from the Crane Creek KGRA and have been well described as a distinct prehistoric technical industry. ${ }^{38}$ Unfortunately, these materials have never been dated, and the artifact assemblages associated with the Midvale Complex frequently do not include temporally diagnostic projectile points. Dort $^{36}$ in his analysis of the Midvale sites' geology noted that the archaeological materials were deposited within a thin soil that could not be reliably dated and that was draped over a much older landform; the sites are usually associated with outcrops of fine-grained basalt and hence are not deeply buried if at all. Warren, Wilkinson, and Pavesic ${ }^{37}$ in their original analys is of the Midvale materials assigned a date of 4500 to 2000 years ago on the basis of the associated projectile points at $10-W N-4$, the Midvale site, but that site yielded little stratigraphy to verify the assignment. Bucy ${ }^{38}$ has not questioned this determination. On the other hand, Reubelmann in his analysis of the Mesa Hill site, another fine-grained basalt quarry and workshop in the Weiser Valley upriver form the Midvale sites and approximately 30 to $35 \mathrm{~km}$ north of the Crane Creek KGRA, assigns this industry to the Cascade period at 7000 to 4000 years ago. ${ }^{39}$ This assignment is quite probable, since it reflects a general correlation of basalt technology and Cascade settlements in the southern Plateau. Coming back to Crane Creek, Bowers noted the presence of this basalt 
assemblage at a series of prehistoric sites east and south of Crane Creek Reservoir, just east of the Crane Creek KGRA. ${ }^{35}$ When one reviews all the available data on the known prehistoric cultural resources in the Crane Creek KGRA vicinity, one must assume that there is a high probability of the KGRA having archaeological materials with considerable time depth, perhaps including the Midvale Complex materials, and reflecting a settlement pattern similar to that of the Spangler locality.

Ethnographically, the lower Weiser valley was a focus of cultural exploitation and interaction, which could be reflected in the Crane Creek KGRA resources. As with the Vulcan area, both the Nez Perce and the Shoshoni moved through the Weiser Valley. Verne Ray recorded Nez Perce temporary fishing and hunting camps at the confluence of the Little and main Weiser Rivers, the west end of modern Crane Creek Reservoir, and the confluence of the Weiser and Snake Rivers (ca. 30 $\mathrm{km}$ north, $10 \mathrm{~km}$ east, and $15 \mathrm{~km}$ west of the Crane Creek KGRA, respectively). This record is again referenced by Schwede, ${ }^{44}$ and Marshal1 ${ }^{45}$ includes the Crane Creek KGRA within his map of ethnographic Nez Perce territory. The Indian Claims Commission ${ }^{46}$ accepted Ray's information as fact but drew their boundary of exclusive Nez Perce territory well to the north of Crane creek. The Commission ${ }^{46}$ did note that one of the principal root digging grounds exploited by the Nez Perce was north and east of Weiser, perhaps in the area now inundated by the Crane Creek Reservoir, and that antelope abounded in this same area and further east and northeast. Chalf ant ${ }^{47}$ noted that the Nez Perce traditionally in the spring with the Shoshoni in the Weiser River Valley near modern Council before travelling to Wyoming to hunt buffalo. His map 47 of the Wyoming trail notes a route passing through the upper Crane Creek Valley approximately 20 to $25 \mathrm{~km}$ east of the Crane Creek KGRA. Chalfant 47 
commented that the Nez Perce obtained "black flint" from a small stream emptying into the Snake from the east, north of Weiser. Thus, the Nez Perce within the last two hundred years were exploiting the lower Weiser Valley for stone materials, plant and animal foods, and social and economic interaction, and quite likely the exploitation included the springs of the Crane Creek KGRA.

The lower Weiser Valley was also popular with the Shoshoni. Steward ${ }^{48}$ reported that the Shoshoni were exploiting the anadromous fish, root crops, and mild winters in that area, and Murphy and Murphy 49 also note the presence of a Shoshoni camp site near the mouth of Crane Creek, within 1 to $2 \mathrm{~km}$ of the Crane Creek KGRA. Nearly all the trappers and traders who travelled along the western Snake River Plain in the early nineteenth century (Figures 28 and 29) comment about finding "Snakes" (Shoshoni) near the confluence of the Weiser and Snake Rivers, and some such as John Work 50 and Wilson Price Hunt ${ }^{51}$ comment on the numerous Shoshoni camps along the Weiser. Hunt 51 on November 28, 1811, encountered "some huts of Chochonis (Shoshoni)" on what appears to be the headwaters of Mann Creek, perhaps $15 \mathrm{~km}$ northwest of the Crane Creek KGRA, an indication that even in winter people were scattered over all elevations of the Weiser Valley.

Reviewing the present archaeological, ethnographic, and ethnohistoric data relative to the Crane Creek KGRA, there is a high probability of finding significant prehistoric cultural resources within the proposed area of development. Materials dating throughout the Late Pleistocene and Holocene could be found there, and the Midvale Complex could well be represented in that locality. Considering Chalfant's ${ }^{47}$ comment that Nez Perce exploitation of the lower Weiser Valley is relatively recent, a function of their agressive strength with their adoption of horses, one would expect a more typical Shoshoni settlement pattern including winter villages to be represented in any KGRA prehistoric resources. An intensive professional archaeological reconnaissance of the KGRA is a first planning requirement. 


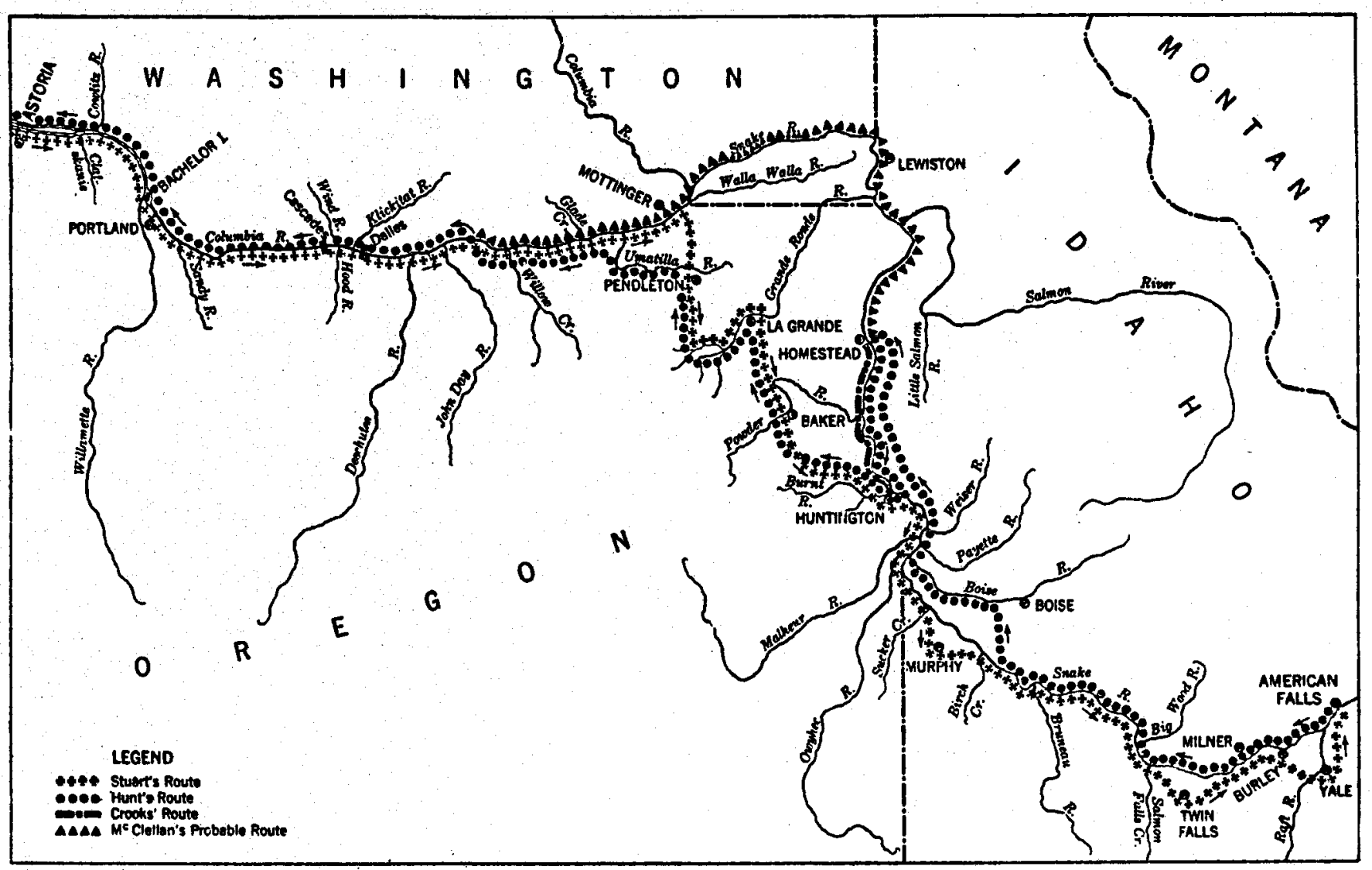

Figure 28. Stuart's and Hunt's routes across southern Idaho (Rollins 1935:2). 


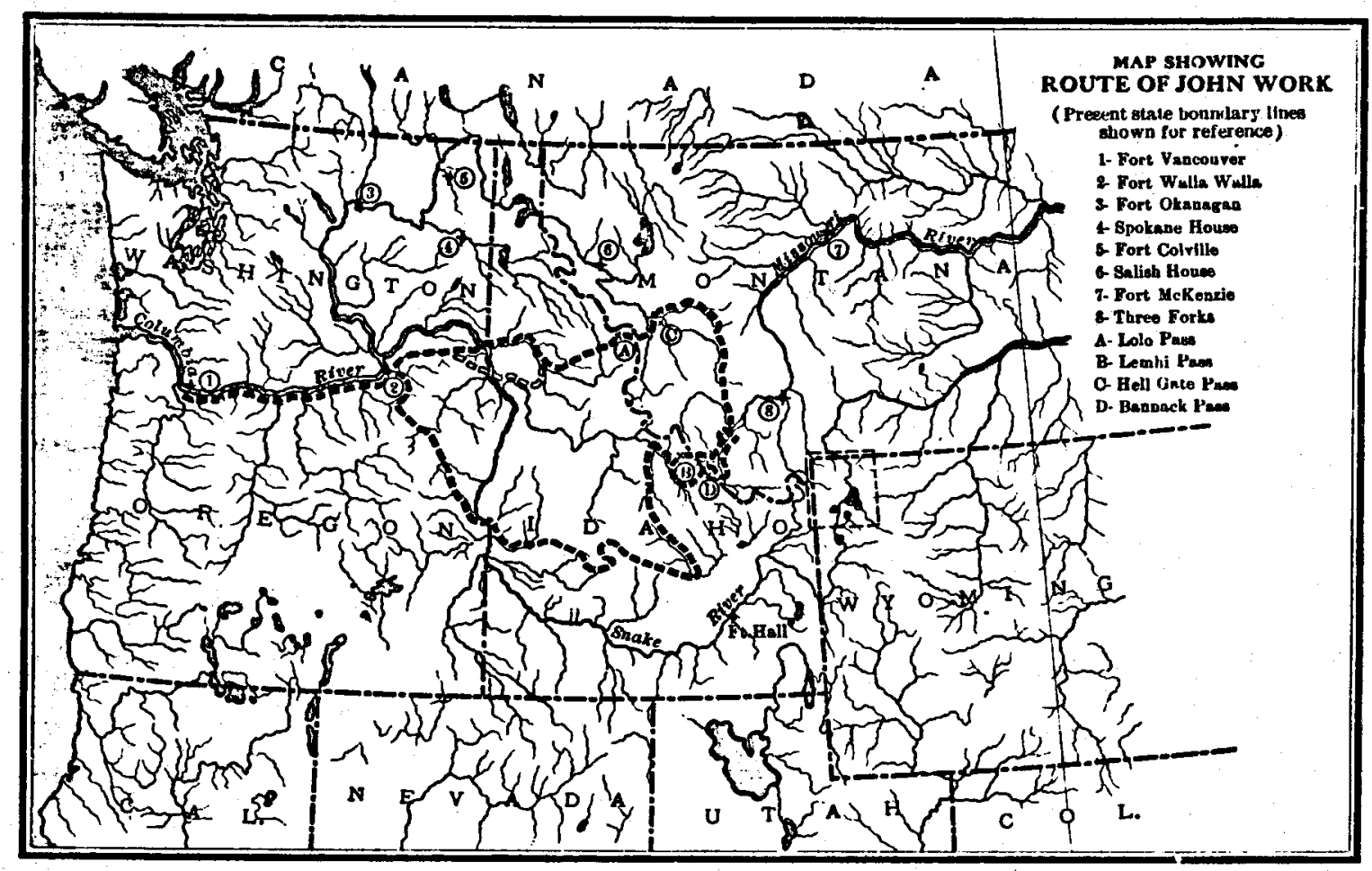

Figure 29. John Work's route across central Idaho. 50 
Historic Resources. Few specific corments about the Crane Creek KGRA are present in the literature, though several traders were in the general Weiser Valley or its mouth in the early nineteenth century. $52,53,54,55,56,57,58$ John Work and his Hudson Bay Company Snake Brigade may even have passed directly through the KGRA. ${ }^{50}$ Apparently, none of them settled there, and no major trading posts were established. The Oregon Trail passed well south of the Weiser Valley, 59 and it was not until the Boise Basin mines opened in the 1860 s that major Euroamerican traffic began to funnel past the Weiser area. 01ds Ferry ${ }^{60}$ was constructed in 1860 or 1861 approximately $20 \mathrm{~km}$. west of modern Weiser and ran across the Snake River from the Idaho side; it continued to operate until 1920 and brought many people to the Weiser area. The Abernathy trading post was built at the ferry site in 1862, and again attracted Euroamericans to the area. The first land surveys ${ }^{61}$ indicate that a house had been constructed within the Crane Creek KGRA by 1870, that there was a school there by 1901, and land titles were finally issued beginning in 1906. Settlement of the lower Weiser Valley certainly was becoming well established by time the Bannock War campaigners travelled through there in 1878,62 and this was supported by construction of the Pacific and Idaho Northern Railroad from Weiser to New Meadows in 1899 to 1902. This railroad passed within 2 to $3 \mathrm{~km}$ west of the Crane Creek KGRA. As with the prehistory of the area, the historic archaeological and architectural resource potential within the KGRA is great and the area merits professional field reconnaissance before further development planning is carried out. 


\section{REFERENCES}

1. S. G. Spencer, B. F. Russell, J. F. Sullivan (ed), Potential Use of Geothermal Resources in the Snake River Basin: An Environment Overview, EGG-2001, September 1979.

2. J. Mitche 11, L. Johnson, J. Anderson, Potential for Direct Heat Application of Geothermal Resources, Water Information Bullet in No. 30, Part 9, 1979.

3. U. S. Weather Service, Climatological Summary, Normal, Means, Extremes, 1937-1957, Boise, Idaho, U. S. Weather Service Forecasting Center, Boise, Idaho.

4. R. Highsmith, Jr., R. Bard, Atlas of the Pacific Northwest, Corvallis, Oregon: Oregon State University Press, 1973.

5. U.S.Q.A. Soil Conservation Service and University of Idaho College of Agriculture, Soil Survey, Gem County Area, Idaho; Series 1958, No. 33, U.S.D.A. Soil Conservation Service, Washington D.C., 1965.

6. U.S.D.A. Soil Conservation Service, the University of Idaho College of Agriculture, and the Bureau of Land Management, Soil Survey of Payette County, Idaho, U.S.D.A. Soil Conservation Service, Washington D.C., 1976.

7. I. J. Witkind (compiler), Prel iminary Map Showing Known and Suspected Active Faults in Idaho, U.S.G.S. Open-File Report 75-278, 1975.

8. D. H. McIntyre, Reconnaisannce Geologic Map of the Weiser Geothermal Area, Washington County, Idaho, U.S.G.S. Misc. Field Study Map No. MF-745, 1:62,500, 1976. 
9. J. F. Poland, "Status of Present Knowledge and Needs for Additional Research on Compaction of Aquifer Systems In Land Subsidence," Proceedings of the Tokoyo Symposium. September 1969, "UNESCO," 1970, pp. 11-71.

10. J. F. Poland, B. E. Lofgren, R. L. Ireland, R. G. Pugh, Land Subsidence in the San Joaquin Valley, California, as of 1972, U. S. Geological Survey Professional Paper 437-H, 1975.

11. B. E. Logren, Land Subsidence Due to Ground-Water Withdrawal, Arvin-Maricopa Area, California, U. S. Geological Survey Professional Paper 437-D, 1975.

12. B. E. Lofgren, Land Subsidence and Tectonism, Raft River Valley, Idaho, U. S. Geological Survey Open-File Report 75-585, 1975.

13. C. R. Allen, "Geological Criteria for Evaluating Seismicity," Geologic Society of America, 86, 1975, pp. 1041-1057.

14. K. R. Vincent, J. K. Applegate, "A Preliminary Evaulation of the Seismicity of Southwestern Idaho and Eastern Oregon; and Implications for Geologic Engineering Studies," Proceedings of the Sixteenth Annual Engineering Geology and Soils Engineering Symposium, Boise, Idaho, 1978, pp. 381-395.

15. M. D. Wilson et a1, Geothermal Investigation of the Cascade, Idaho Area, Boise State University Contribution No. 101, 1976.

16. L. S. Cluff, I. M. Idriss, Investigation and Evaluation of the Potential Activity of the Boise Fault, Veterans Administration Project No. 11-5045, 1972.

17. R. F. Hardyman, "Seismicity," Personal Communication, 1978. 
18. D. M. Henderson, F. D. Johnson, P. Packard, R. Steele, "Endangered and Threatened Plants of Idaho," University of Idaho Forestry and Wildlife Range Experiment Station Bulletin 21, 1977.

19. Idaho Department of Fish and Game, Species Report (Computer-Programmed Species Inventory), Boise, Idaho, 1977.

20. R. C. Stebbins, Amphibians and Reptiles of Western North America, New York: McGraw-Hill, 1954.

21. R. C. Stebbins, A Field Guide to Western Reptiles and Amphibians, Boston: Houghton Mifflin, 1966.

22. I. S. Graetzer, Environmental Analysis Record: Geothermal Leasing For Crane Creek KGRA and Adjacent Areas, U. S. Bureau of Land Management, Boise, Idaho, 1974.

23. E. Chaney, The Sagebrush -- Grass Ecosystem: Description of the Existing Environment, U. S. Bureau of Land Management, Boise, Idaho, 1974.

24. T. D. Burleigh, Birds of Idaho, Caldwe 11: Caxton Printers, 1972.

25. C. S. Robbins, B. Brunn, H. S. Zim, Birds of North America: A Guide to Field Identification, Racine: Western Publishing Company, 1966.

26. R. T. Peterson, A Field Guide to Western Birds, 2nd edition, Boston: Houghton Mifflin Company, 1961.

27. W. H. Burt, A Field Guide to the Mammats, Boston: Houghton Mifflin Company, 1964.

28. E. J. Larrison, "Guide to Idaho Mammals," Journal of the Idaho Academy of Sciences, 7, 1967. 
29. Idaho Department of Water Resources, Idaho Department of Health and Welfare, Idaho Department of Fish and Game, Idaho Division of Budget, Policy Planning and Coordination, Idaho Environmental Overview, 1975.

30. H. Gibson, Snake River Fisheries Investigation. Job 111b, Survey of the Fish Populations in the Snake River from (1) Brownlee Flowline to Proposed Guffey Dam Site (near Murphy, Idaho); (2) Grandview, Idaho to C. J. Strike Dam. Job Performance Report F-63-R-3, March 1, 1973 to February 28, 1974. (Idaho Fish and Game Vol. 31, Part II, No. 23. Castle (reek).

31. H. W. Young et al, Water Resources of the Weiser River Basin, West-Central Idaho, Idaho Department of Water Resources Water Information Bulletin No. 44, 1977.

32. J. E. Mckee and H. W. Wolf, Water Quality Criteria, The Resources Agency of California, State Water Resources Control Board, 1963.

33. S. M. I. Shah, Stratigraphic Paleobotany of the Weiser Area. Doctoral Dissertation, University of Idaho, 1968.

34. J. G. Bond (compiler), John D. Kauffman, Donald A. Miller, Ramesh Venkatakrishnan; Clifford H. Wood, Cartographer, with Philip J. Hearn, Garrett E. Kirby, and Gary McManus, 1978 Geologic Map of Idaho, Moscow, Idaho: Idaho Department of Lands, Idaho Bureau of Mines and Geology with U. S. Geological Survey.

35. A. W. Bowers, Archeological Excavations in the Spangler Reservoir and Surveys in Washington County, Idaho, Ms, Interagency Archeological Services-San Francisco (HCRS, USDI) and the Archive of Pacific Northwest Archaeology, University of Idaho, Moscow (1967). 
36. W. Dort, Jr., "Geology of the Midvale Site Complex, Idaho," Tebiwa 7 1, 1964, pp. 7-22.

37. C. N. Warren, S. Wilkinson, M. Pavesic, "The Midvale Complex," Tebiwa 14 2, 1971, pp. 39-71.

38. D. R. Bucy, "A Technological Analysis of a Basalt Quarry in Western Idaho," Tebiwa 16 2, 1974, pp. 1-45.

39. G. H. Reubelmann, "The Archaeology of the Mesa Hill Site, a Prehistoric Workshop in the Southeastern Columbia Plateau," University of Idaho Anthropological Research Manuscript Series No. $9,1973$.

40. M. G. Pavesic, The Archaeology of Hells Canyon Creek Rockshelter, Wall lowa County, Oregon, Doctoral Dissertation, University of Colorado, 1971.

41. J. E. Randolph, "Hells Canyon Archaeology, 1974, a Report of Investigations," University of Idaho Anthropological Research Manuscript Series No. 26, 1976.

42. J. E. Randolph, "Archaeological Test Excavation at Bernard Creek Rockshelter," University of Idaho Anthropological Research Manuscript Series No. 42, 1977.

43. S. J. Miller, W. Dort Jr., "Early Man at Owl Cave: Current Investigations at the Wasden Site, Castern Snake River Plain, Idaho," In Early Man in America from a Circum-Pacific Perspective, 1978, pp. 129-139. (Department of Anthropology, University of Alberta, Occasional Papers No. 1).

44. M. L. Schwede, An Ecological Study of the Nez Perce Settlement Patterns, Masters Thesis, Washington State University, 1966. 
45. A. G. Marshal1, Nez Perce Social Groups: An Ecological Interpretation, Doctoral Dissertation, Washington State University, 1977.

46. Indian Claims Commission, "Findings of Fact," in Shoshoni Indians, New York: Garland Publishing, Inc., 1974.

47. S. A. Chalfant, "Aboriginal Territory of the Nez Perce Indians," in Nez Perce Indians, New York: Garl and Publishing Company, 1974.

48. J. H. Steward, Basin-Plateau Aboriginal Sociopol itical Groups, Smithsonian Institution, Bureau of American Ethnology, Bulletin 120. (Reprinted 1970, University of Utah Press, Salt Lake City).

49. R. F. Murphy, Y. Murphy, "Shoshone - Bannock Subsistence and Society," University of California Anthropological Records 167 , 1960, pp. 293-338.

50. W. S. Lewis, and C. Phillips (ed), The Journal of John Work, Cleveland: Arthur H. Clark. Company, 1923.

51. P. A. Rollins, (ed), The Discovery of the Oregon Trail. Robert Stuart's Narratives ... to Which is Added .... Wilson Price Hunt's Diary ... New York: Charles Scribner's Sons, 1935.

52. T. J. Farnham, Travels in the Great Western Prairies, the Anahuac and the Rocky Mountains, and in the Oregon Territory, New York: Greeley and McElrath, Tribune Buildings, 1843.

53. W. Irving, The Adventures of Captain Bonneville, New York: Thomas Y. Crowell and Company, 1843a.

54. D. Jackson, M. L. Spence (ed), The Expeditions of John Charles Fremont. Vol. I, Travels from 1838 to 1844, Urbana: University of Illinois Press, 1970. 
55. E. E. Rich, (ed), Peter Skene Ogden's Snake Country Journals 1824-25 and 1825-26, London: The Hudson's Bay Record Society, 1950.

56. R. G. Thwaites, Early Western Travels 1784-1846, Cleveland: Arthur H. Clark Company, 1905-1906, pp. 28-30.

57. G. Williams, Peter Skene Ogden's Snake Country Journals 1827-28 and 1828-29, London: The Hudson's Bay Record Society, 1971.

58. F. G. Young, (ed), "The Correspondence and Journals of Captain Nathaniel J. Wyeth, 1831-6," Sources of the History of Oregon 1, 1899, pp. 3-6.

59. Idaho Department of Highways, Route of the Oregon Trail in Idaho, Boise: Idaho Department of Highways, with the Bureau of Public Roads, U. S. Department of Transporation, 1963.

60. F. Foster, "01d Ferries," Twentieth Biennial Report of the Idaho State Historical Society, 1946, pp. 45-53.

61. U: S. Department of the Interior, Archaeological Site Record File, Ms, Boise District Office, Bureau of Land Managment, U. S. Department of the. Interior, n.d.

62. G. F. Brimlow, The Bannack Indian War of 1878, Caldwell, Idaho: The Caxton Printers, Ltd 1938.

63. M. D. Beal, M. Wells, History of Idaho, Vol. 1, New York: Lewis Historical Publishing Company, 1959. 
APPENDIX A

SNAKE RIVER BASIN OVERVIEW REPORTS

AND SUPPORTING DOCUMENTS 
e 
The reports, prepared as part of the Snake River Basin environmental program, are listed. Copies of these reports are available from the Information Processing of the Information Division at EG\&G Idaho, Inc., Box 1625, Idaho Falls, Idaho 83401. I

EGG-2001 "Potential Use of Geothermal Resources in the Snake River Basin: An Environmental Overview," S. G. Spencer, B. F. Russell, and J. S. Sullivan, editors.

EGG-GTH-5001 "Vulcan Hot Springs KGRA: An Environmental Analysis," S. G. Spencer and B. F. Russell, editons.

EGG-GTH-5002 "Crane Creek KGRA: An Environmental Analysis," S. G. Spencer and B. F. Russell, editors.

EGG-GTH-5003 "Castle Creek KGRA: An Environmental Analysis," S. G. Spencer and B. F. Russe11, editors.

EGG-GTH-5004 "Bruneau KGRA: An Environmental Analysis," S. G. Spencer and B. F. Russell, editors.

EGG-GTH-5005 "Mountain Home KGRA: An Environmental Analys is," S. G. Spencer and B. F. Russe11, editors.

EGG-GTH-5006 "Raft River KGRA: An Environmental Analysis," S. G. Spencer and B. F. Russell, editors.

EGG-GTH-5007 "Geothermal Development in Southwest Idaho: The Socioeconomic Data Base," W. C. Lewis, Lewis \& Associates.

PG-G-79-001 "KGRA Comprehensive Completion Report: Seismicity," J. K. Applegate, GeoTechniques. 
PG-G-79-002 "KGRA Comprehensive Completion Report: Subsidence," J. K. Applegate, GeoTechniques.

PG-G-79-003 "Snake River Basin KGRA Environmental Report: Soi1s," N. Savage, Idaho Water Resources Research Institute.

PG-G-79-004 "KGRA Comprehensive Completion Report: Air Quality," E. Bentley, GeoTechniques.

PG-G-79-005 "KGRA Comprehensive Completion Report: Meteorology," M. Delisio, GeoTechniques.

PG-G-79-006 "Heritage Resources and Known Geothermal Resource Areas in Idaho: A Preliminary Review," R. Knudson and M. Pfaff, Idaho Water Resources Research Institute.

PG-G-79-007 "Assessment of Hydrology and Water Quality Data of the KGRAs of the Snake River Basin," C. L. Miller and C. C. Warnick, Idaho Water Resources Research Institute.

PG-G-79-008 "KGRA Comprehensive Completion Report: Geology," R. Hardyman, GeoTechniques.

PG-G-79-010 "Aquatics of Five Snake River Basin KGRAs," K. P. McCarthy and J. F. Sullivan, EG\&G Idaho, Inc.

PG-G-79-011 "A Sumary of the Assessments of Geothermal Resource Use Limitations of Bruneau, Castle Creek, Crane Creek, Mountain Home, and Vulcan Hot Springs KGRAs," B. Moore, N. Savage, J. S. Gl adwe11, and C. C. Warnick, Idaho Water Resources Research Institute. 